Provided for non-commercial research and education use. Not for reproduction, distribution or commercial use.

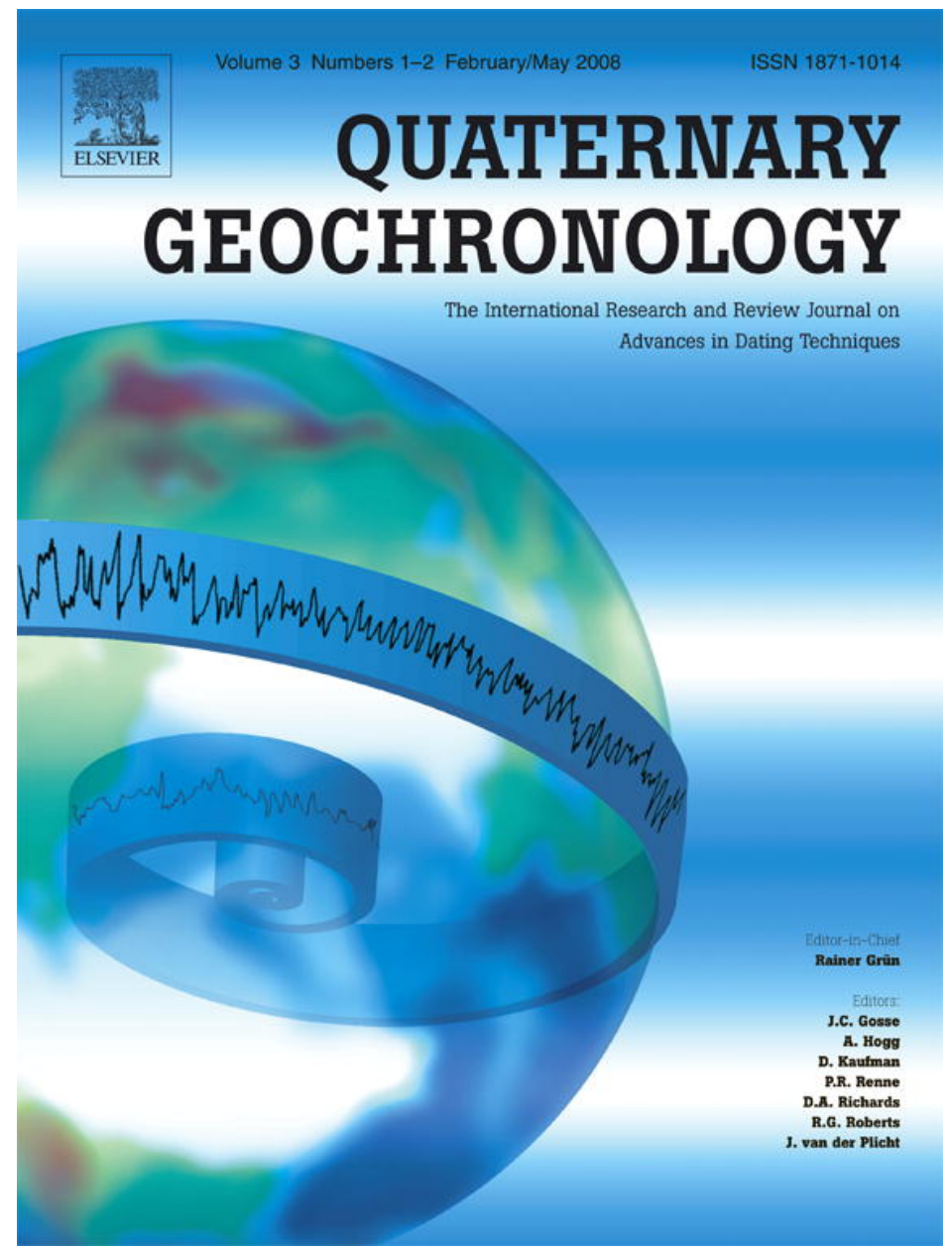

This article was published in an Elsevier journal. The attached copy

is furnished to the author for non-commercial research and education use, including for instruction at the author's institution, sharing with colleagues and providing to institution administration.

Other uses, including reproduction and distribution, or selling or licensing copies, or posting to personal, institutional or third party websites are prohibited.

In most cases authors are permitted to post their version of the article (e.g. in Word or Tex form) to their personal website or institutional repository. Authors requiring further information regarding Elsevier's archiving and manuscript policies are encouraged to visit: 


\author{
Research paper
}

\title{
Carbonate eolianites, quartz sands, and Quaternary sea-level cycles, Western Australia: A chronostratigraphic approach
}

\author{
Paul J. Hearty ${ }^{\mathrm{a}, *}$, Michael J. O'Leary ${ }^{\mathrm{b}}$ \\ ${ }^{a}$ School of Earth and Environmental Sciences, University of Wollongong, Wollongong, NSW 2522, Australia \\ ${ }^{\mathrm{b}}$ Department of Environmental \& Geographical Sciences, Manchester Metropolitan University, Manchester M1 5GD, UK
}

Received 16 June 2007; received in revised form 26 September 2007; accepted 3 October 2007

Available online 10 October 2007

\begin{abstract}
Marine and eolian carbonate deposits, grouped under the name "Tamala Limestone", have been investigated along thousands of kilometers of coastal Western Australia (WA). Relative-age diagenetic features of carbonate sand dunes or "eolianites" indicate that coastal ridges decrease in age seaward, reflecting coastal accretion during successive sea-level stands. Yellow- to red-stained quartz sands are associated with eolianites as pits, lenses, extensive beds, and even 40-m-high dunes.

A regional survey using whole-rock and land snail amino acid epimerization geochronology confirms the eolianite succession and provides a means of correlating widespread deposits along a steep climatic gradient and $16^{\circ}$ of latitude. AMS ${ }^{14} \mathrm{C}$ and uranium-thorium $(\mathrm{U} / \mathrm{Th})$ ages provide independent radiometric calibration of the amino acid ratios, and eolianite ages can be estimated using a parabolic kinetic model.

Over $90 \%$ of the sampled eolianite deposits comprise Aminozones A, C, E (125 ka), F?, G, and H, and correlate with interglacials from $<10 \mathrm{ka}$ (Holocene) to ca. $500 \mathrm{ka}$. In contrast, at the type locality of the Tamala Limestone along the Zuytdorp Cliffs, the upper eolianitepaleosol units are characterized by advanced stages of cavernous weathering, pedogenesis, and recrystallization. In the same units, sediment and snail samples generally yield very low or non-detectable levels of amino acids. These factors along with the stratigraphic complexity of the deposits reflect an age much greater than a large majority of sites along the WA coastline. These findings encourage a revision of the existing classification and nomenclature of Quaternary carbonate deposits in WA, as well as a reexamination of the underlying mechanisms related to the formation and emplacement of both carbonate and quartz dunes.
\end{abstract}

(C) 2007 Elsevier Ltd. All rights reserved.

Keywords: Western Australia; Eolianite; Amino acid epimerization dating; Whole-rock; Bothriembryon land snails; Limestone diagenesis; Quaternary sealevel cycles; Tamala Limestone

\section{Introduction}

Coastal carbonate sediments and rocks representing subtidal, beach, and supratidal facies abound in Western Australia (WA), particularly from Shark Bay southward, where prevailing winds are generally onshore (Fig. 1). In Bermuda, which serves as a model for the interpretation of coastal eolianites, similar biogenic dune deposits were defined as "eolianites" by Sayles (1931). Sayles (1931) originally suggested that carbonate eolianites were glacialage dunes deposits that migrate across exposed shelf areas.

\footnotetext{
*Corresponding author.

E-mail address: paulh@uow.edu.au (P.J. Hearty).
}

Bretz (1960) later reversed this perspective by demonstrating eolianites are a supratidal facies of coastal subtidal and beach deposits, and thus correlated them with highstand cycles which remains the prevalent global view. In WA, Fairbridge and Teichert (1953), and many others to follow, maintained a model of eolianite deposition during periods of glacially lowered sea level.

Eolianites generally form a broad coastal ridge parallel to the coast, and are volumetrically dominant on many subtropical coastlines (Brooke, 2001). However, with the exception of well-dated reef deposits ca. $125 \mathrm{ka}$ (Stirling et al., 1995, 1998; O'Leary, 2007; O'Leary et al., in press, in review), there is little consensus in WA on virtually any aspect of carbonate dune deposits including their 


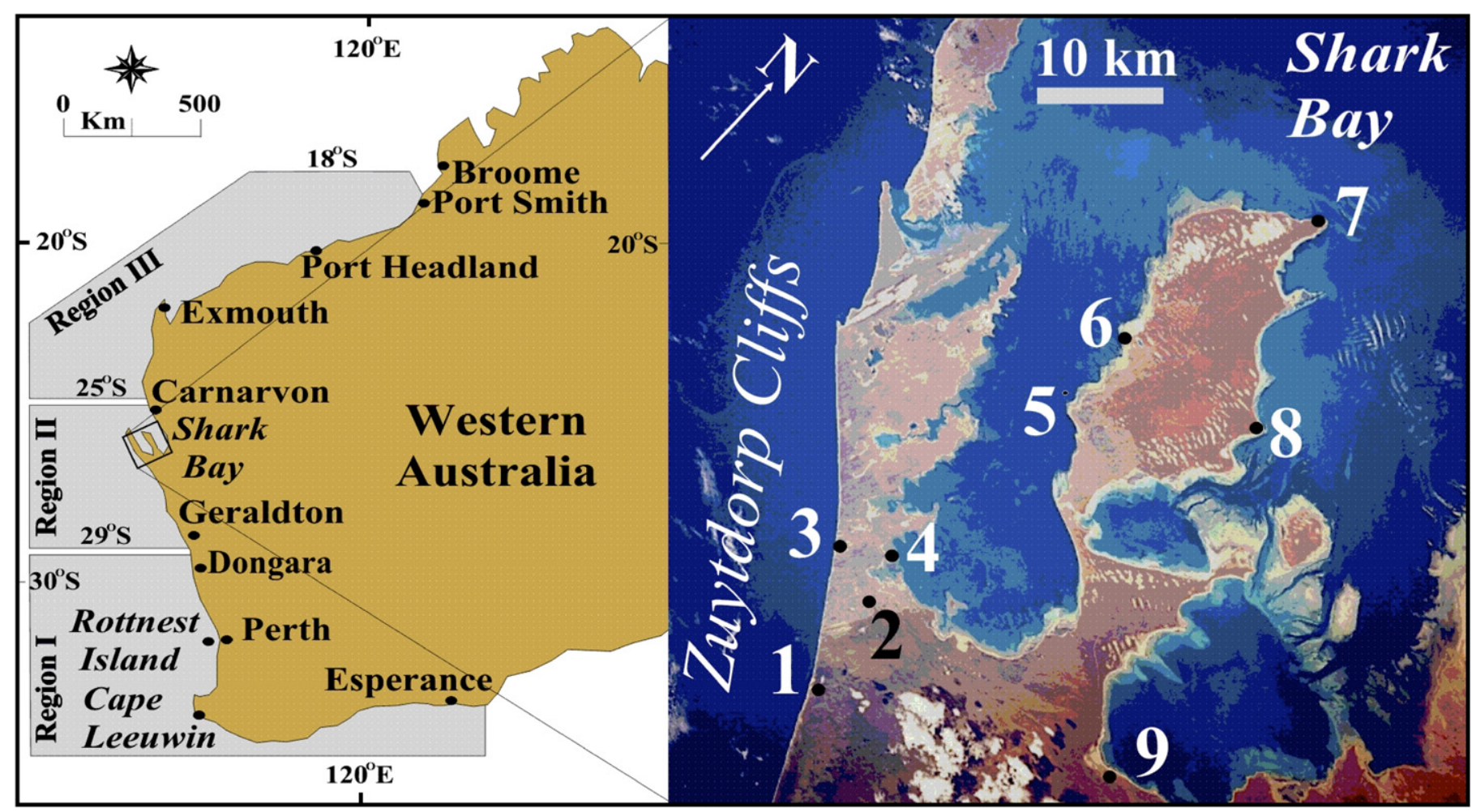

Fig. 1. WA map showing study Regions I, II, and III. The steep climate gradient between cool temperate and dry tropical conditions encompassed by these regions are reflected in amino acid ratios. Image on right is an oblique satellite image of Shark Bay with site numbers: (1) Woomerangee Hill at Zuytdorp Cliffs, the type locality of the Tamala limestone; (2) Tamala Station; (3) Monkey Tarra; (4) Baba Head; (5) Eagle Bluff and Eagle Island; (6) Town of Denham; (7) Cape Peron (type locality of the Peron Sandstone); (8) Monkey Mia; (9) Hamelin Pool and stromatolites.

provenance, mechanism of transport (e.g., migration or aggradation), age of formation, and timing of dune emplacement relative to sea-level cycles. In this investigation, we focus on four important issues: (1) the abundance and distribution of Quaternary carbonate dunes (henceforth "carbonate dunes or eolianites") of various ages; (2) the origin and significance of interbedded quartz deposits including dunes on the coastal plain; (3) the formation and age of the Tamala Limestone at the type locality along the Zuytdorp Cliffs, and; (4) the relevance and suitability of this type locality to represent eolianite deposits across WA (Table 1). We address these questions primarily through a regional chronostratigraphic survey of sites correlated and dated with amino acid epimerization (AAE) geochronology, AMS ${ }^{14} \mathrm{C}$, and $\mathrm{U} / \mathrm{Th}$ ages.

\subsection{Eolianites in $W A$}

The dearth of scientific information about eolianites in WA is partially attributed to the remoteness of the coastline outside of Perth, the sheer scale of the deposits, and to the limitations in available dating methods. The effective range of AMS ${ }^{14} \mathrm{C}$ is too short to be relevant to most Pleistocene deposits, while pristine in situ corals, required for $\mathrm{U} / \mathrm{Th}$ dating, occur in only a handful of exposures of reef facies in the region. In contrast, eolianite ridges occur throughout coastal WA. The development of whole-rock (WR) aminostratigraphy (Hearty et al., 1992) offers new opportunities to correlate and date Quaternary carbonates, particularly eolianites that generally lack macrofossils.

In Fig. 2, a facies model developed from Bahamian studies (Hearty and Kindler, 1997) represents eolianites as highstand supratidal facies. The highstand eolianite model has a strong basis in previous research. This investigation is preceded by a number of aminostratigraphic studies, which also employ coastal geomorphology, stratigraphy, and sedimentology from the Mediterranean (Hearty et al., 1986), Bermuda (Hearty et al., 1992; Hearty, 2002a), Bahamas (Hearty et al., 1996; Hearty and Kaufman, 2000), Hawaiian Islands (Hearty et al., 2000, 2005a, b; Hearty, 2002b; Fletcher et al., 2005), South Australia (MurrayWallace et al., 2001), and WA (Murray-Wallace and Kimber, 1989; Hearty, 2003). These studies offer numerous examples of coastal facies relationships between shore and dunes, and demonstrate the effectiveness and reliability of the AAE approach. Through AAE, it is possible to group sites according to relative age, determine the relative abundance of sites of similar age, and to make generalizations about the likely correlation with several past sealevel cycles.

\subsection{Interbedded deposits of quartz sand}

In WA, eolianites consistently contain a small percentage of quartz and lithic grains, which are presumably 
Table 1

Stratigraphic nomenclature and correlation of units in Perth and Carnarvon Basins, Western Australia

\begin{tabular}{|c|c|c|c|c|c|c|}
\hline 雚 & 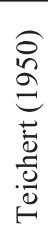 & 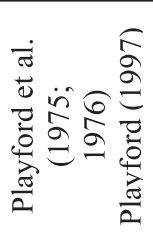 & $\begin{array}{l}\text { Logan et al. } \\
(1970 ; 1974)\end{array}$ & $\begin{array}{c}\text { Rottnest/ } \\
\text { Perth area } \\
\text { Murray-Wallace } \\
\text { and Kimber, } \\
\text { (1989) } \\
\text { Hearty } \\
\text { (2003) in bold }\end{array}$ & $\begin{array}{c}\text { Shark Bay } \\
\text { Eagle Bluff } \\
\text { and Lookout } \\
\text { (this study in } \\
\text { Bold) }\end{array}$ & $\begin{array}{c}\text { MIS } \\
\text { correla- } \\
\text { tion } \\
\text { (this study) }\end{array}$ \\
\hline
\end{tabular}

\begin{tabular}{|c|c|c|c|c|c|c|}
\hline \multirow{2}{*}{$\begin{array}{l}\stackrel{0}{0} \\
\stackrel{0}{0} \\
\frac{0}{0} \\
\text { I }\end{array}$} & \multirow{9}{*}{ 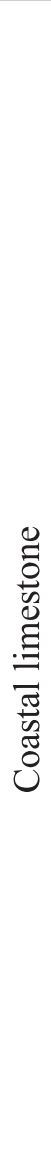 } & \multirow{11}{*}{ 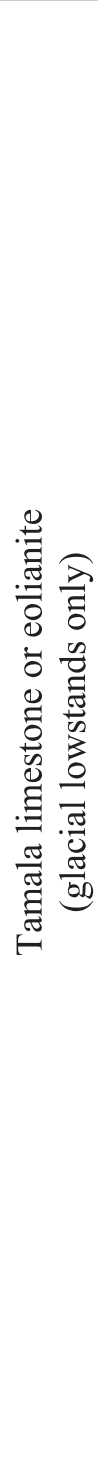 } & \multirow[t]{2}{*}{$\begin{array}{l}\text { Holocene- } \\
\text { recent interval }\end{array}$} & $\begin{array}{c}\text { Modern/subrecent } \\
\text { beach and dune }\end{array}$ & \multirow{2}{*}{$\begin{array}{c}\text { Unit } \mathbf{x} \\
\text { Eolianite and } \\
\text { marine } \\
\text { Unit } \mathbf{m} \\
\text { Marine quartz } \\
\text { and carbonate }\end{array}$} & \multirow[t]{2}{*}{1} \\
\hline & & & & $\begin{array}{c}\text { Holocene beach } \\
\text { and dune } \\
\text { Unit VI }\end{array}$ & & \\
\hline \multirow{4}{*}{$\begin{array}{l}\stackrel{0}{0} \\
\dot{0} \\
\stackrel{0}{0} \\
\stackrel{0}{0} \cdot \frac{0}{\frac{0}{2}}\end{array}$} & & & \multirow{3}{*}{ Nilemah sands } & paleosol & $\begin{array}{c}\text { Unit l } \\
\text { Quartz dunes }\end{array}$ & $\begin{array}{l}2 \\
\Downarrow \\
4\end{array}$ \\
\hline & & & & $\begin{array}{c}\text { Fish Hook Bay } \\
\text { eolianites } \\
\text { Unit V }\end{array}$ & $\begin{array}{c}\text { Unit k } \\
\text { Carbonate } \\
\text { dunes }\end{array}$ & $\begin{array}{c}5 \mathrm{a} \\
\Downarrow \\
5 \mathrm{c}\end{array}$ \\
\hline & & & & paleosol & $\begin{array}{c}\text { Unit i-j } \\
\text { Pisolith and } \\
\text { quartz dune }\end{array}$ & $5 \mathrm{~d}$ \\
\hline & & & $\begin{array}{l}\text { Bibra } \\
\text { Formation; } \\
\text { marine reef; } \\
\text { oolite; dunes }\end{array}$ & $\begin{array}{c}\text { Rottnest } \\
\text { Limestone/ } \\
\text { Minim Cove - } \\
\text { marine and } \\
\text { eolianites } \\
\text { Unit IV }\end{array}$ & $\begin{array}{c}\text { Unit h } \\
\text { Marine and } \\
\text { eolianites }\end{array}$ & $5 \mathrm{e}$ \\
\hline \multirow{3}{*}{ 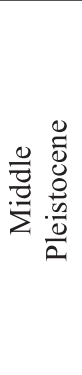 } & & & $\begin{array}{l}\text { Dampier } \\
\text { Formation }\end{array}$ & $\begin{array}{c}\text { Peppermint Grove } \\
\text { marine and } \\
\text { eolianites } \\
\text { Unit III }\end{array}$ & $\begin{array}{c}\text { Unit b-g } \\
\text { Continental } \\
\text { dune cycles; } \\
\text { no marine? }\end{array}$ & \multirow{2}{*}{$\begin{array}{c}7 \\
\Downarrow \\
11-15\end{array}$} \\
\hline & & & Carbla oolite? & $\begin{array}{c}\text { Guilderton Quarry } \\
\text { eolianite/ } \\
\text { Pinnacles } \\
\text { Unit II }\end{array}$ & $\begin{array}{c}\text { Unit a } \\
\text { Eagle Island? } \\
\text { Baba Head; } \\
\text { Tetradon } \\
\text { yellow oolite }\end{array}$ & \\
\hline & & & \multicolumn{4}{|c|}{ Major hiatus in coastal highstand record (MIS 15-25?) } \\
\hline \multirow{2}{*}{ 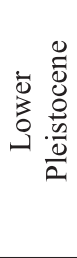 } & & & $\begin{array}{l}\text { Tamala } \\
\text { Eolianite }\end{array}$ & \multirow{2}{*}{$\begin{array}{l}\text { Yoganup Fm } \\
\text { Unit I }\end{array}$} & $\begin{array}{l}\text { Zuytdorp } \\
\text { Cliffs }\end{array}$ & \multirow{2}{*}{$\begin{array}{c}25 ? \\
\Downarrow \\
>37 ?\end{array}$} \\
\hline & & & $\begin{array}{c}\text { Peron } \\
\text { Sandstone }\end{array}$ & & $\begin{array}{l}\text { Old quartz } \\
\text { dunes, Peron } \\
\text { Peninsula; } \\
\text { Monkey Mia }\end{array}$ & \\
\hline
\end{tabular}

incorporated into carbonate beach and dunes during the erosive action of underlying continental sediments during marine transgressions (Hearty, 2003). The abundance of quartz sand is generally less than $10 \%$ in eolianites (Table 2), while soil and paleosol horizons generally contain higher proportions of quartz grains. In many examples, eolianites are interbedded with, or overlain by decimeters to meters of yellow to red, nearly pure $(>95 \%)$ quartz sand (Allayialis, 2003). Pure quartz sands also infill pits in eolianite (Fig. 3).
The source of these quartz deposits is inextricably interwoven with the discussion of eolianites. One school of thought maintains that the quartz sand deposits result from dissolution of the carbonate sediments by meteoric waters, thus creating concentrations of quartz grains or "residual soils" (e.g., Bastian, 1996). An opposing view is that the quartz is distributed seaward (westward) across the coastal plain by migrating continental dunes during periods of lower sea level (or "desert expansion" of Semeniuk and Glassford, 1988). 


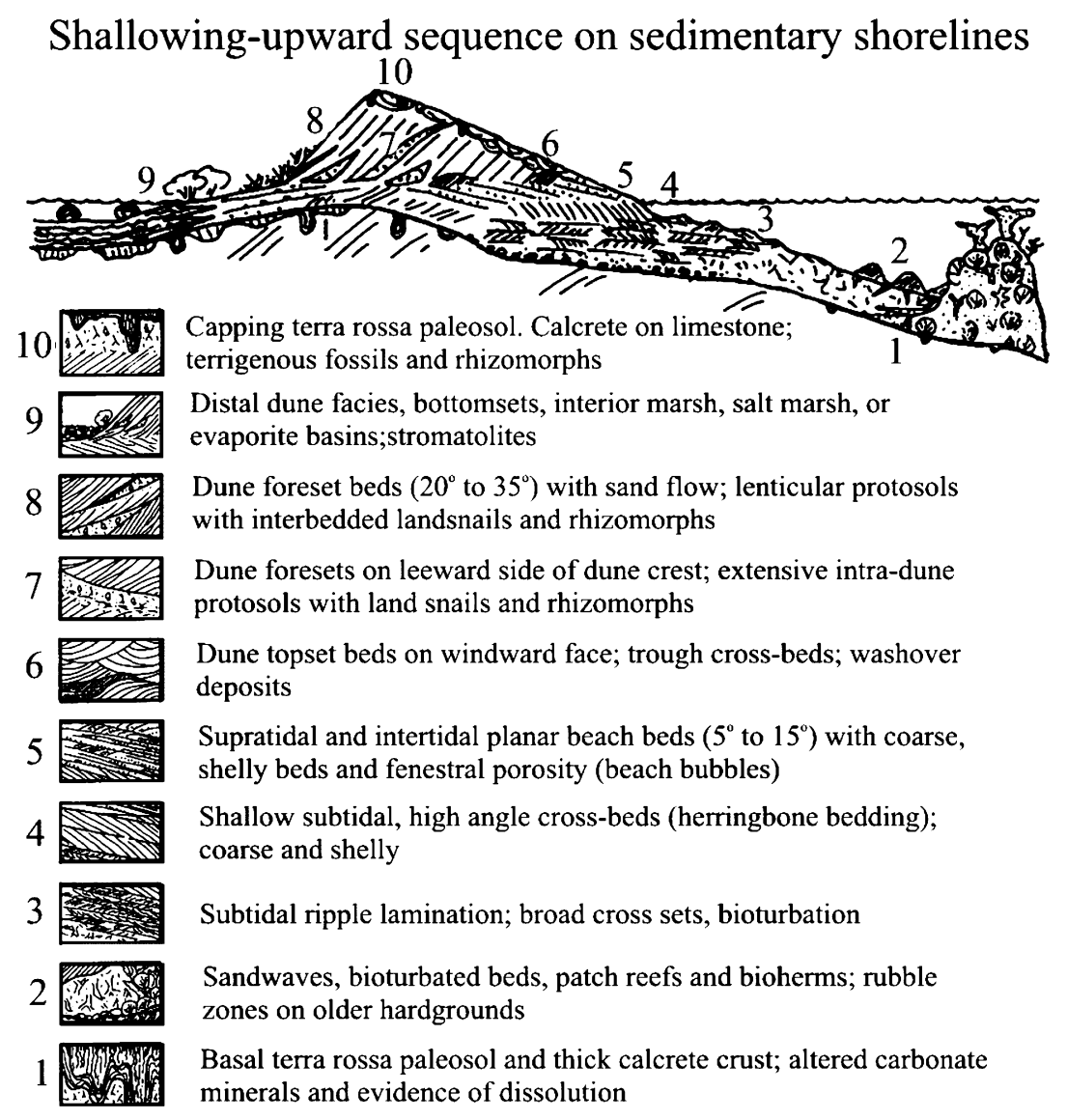

Fig. 2. A subtidal to supratidal (dune) structural transect across a typical sediment-dominated coastline (after Hearty and Kindler, 1997). The shallowingupward facies model is representative of typical Holocene and older interglacial sequences of Western Australia, and implies association with sea-level highstand intervals.

\subsection{The type locality of the "Tamala Limestone"}

The Zuytdorp Cliffs of central coastal WA maintain an important distinction as the type locality of the Tamala Limestone, representing Quaternary coastal eolianites in the Shark Bay area (Logan et al., 1970) and across all of WA (Playford et al., 1975, 1976). Playford's (1990, 1997) broader definitions would encompass widespread and voluminous carbonate marine and eolianite deposits along $5000 \mathrm{~km}$ of WA coastline and span over $1 \mathrm{Ma}$. Despite this impressive status, neither a detailed description of the deposits nor any geochronology has been published from the type area.

Teichert (1950) first referred to the assemblage of marine and eolianite deposits along the coast of WA as the "coastal limestone" (Table 1). Brian Logan and colleagues later discussed (in Gill, 1968) and defined (Logan et al., 1970 , p. 52) the "Tamala eolianite (as) a vast complex of dunes which rise... up to $500 \mathrm{ft}$ above present sea level". They specified no type locality, but presumably were referring to the adjacent Zuytdorp Cliffs several kilometers west of Tamala Cattle Station (Fig. 1). They characterized the deposits as "consolidated to unconsolidated, coarse- to medium-grained, skeletal-fragment grainstone which commonly shows large-scale (eolian) cross-bedding". They assigned an early Pleistocene age to these deposits (their Table 2, p. 51). The name "Tamala" was thus adopted to represent Quaternary eolianites, first in Shark Bay, and subsequently in all of WA (Fig. 1).

Playford et al. (1975) identified a site at $+258 \mathrm{~m}$ elevation at Woomerangee Hill $\left(26.884^{\circ} \mathrm{S}\right.$. lat., $113.749^{\circ} \mathrm{E}$. long) along the Zuytdorp Cliffs as the type locality (Fig. 1), and measured a $251 \mathrm{~m}$ section. Playford et al. (1975) concurred with Logan et al.'s (1970) general description of the sediments, but regarding the age, they stated (p. 307) "the eolianite extends below present sea level, and it seems more likely that it formed during one of the glacial regressions, probably in late Pleistocene times". Playford et al. (1976) then expanded the definition to include carbonate dunes in the Perth and Carnarvon Basins, and reiterated their opinion that the deposits were formed during a late Pleistocene glacial age. Playford (1990, p. 20) later broadened his definition to include "accumulation during (multiple) glacial periods." And more recently, Playford (1997, p. 794) stated "the Tamala Limestone accumulated as coastal sand dunes, mostly during periods of lowered sea level during the Pleistocene and early Holocene, when wide areas of the continental shelf were exposed, and carbonate productivity was high." 
Table 2

Carbonate content and color of quartz pits, lenses, beds and dune deposits from sampled localities in WA (from Allayialis, 2003)

\begin{tabular}{|c|c|c|c|c|c|}
\hline Site location & Sample ID & $\begin{array}{l}\text { Dated sample (this } \\
\text { study) }\end{array}$ & $\begin{array}{l}\text { Estimated age of } \\
\text { quartz (MIS) }^{\mathrm{a}}\end{array}$ & $\%$ Carbonate & $\begin{array}{l}\text { Munsell (2002) moist } \\
\text { color }\end{array}$ \\
\hline Port Smith & $\operatorname{BSM} 2 \mathrm{x}$ & BSM1ab & $4-2$ & 9 & 5YR 5.5/6 \\
\hline Pardoo & BPO1 & Continental dune & Post 5? & 0 & $10 \mathrm{R} 5 / 8$ \\
\hline \multirow[t]{2}{*}{ Vlaming Head } & NVL1; & & Post 5e & 12 & $2.5 \mathrm{YR} 4 / 8$ \\
\hline & NVL1d & & Pre 1 & 9 & \\
\hline \multirow[t]{2}{*}{ Exmouth } & WEX1a & & & & \\
\hline & WEX $2 \mathrm{a}$ & & Post 9/11 & 7 & $5-7.5 Y R 6 / 6$ \\
\hline Vlaming Head & WVL3a & & & 8 & $5 Y R 6 / 6$ \\
\hline Milnya & MY1 & Continental dune & & 0 & 2.5 YR 5/8 \\
\hline \multirow[t]{2}{*}{ Broadhurst North } & SBN1a; & & & 0 & 2/5YR 4.5/8 \\
\hline & SBN1e & & & 0 & $2.5 \mathrm{YR} 4 / 8$ \\
\hline Billabong & BB25 & Continental dune & & 0 & 5YR $4.5 / 6$ \\
\hline White Point & WWP2b & $\begin{array}{l}\text { WWP2a } 0.42 \\
\text { WWP1a } 0.40\end{array}$ & Post 5e & 0 & 10YR 7/8 \\
\hline Leeman & WLE2b & $\begin{array}{l}\text { WLE1a } 0.35 \\
\text { WLE2x } 0.22\end{array}$ & $\begin{array}{l}\text { Post 5e } \\
\text { Pre early } 1\end{array}$ & 1 & $7.5 Y R 5.5 / 6$ \\
\hline Jurien & WJR1b & WJR1a 0.46 & 6 or 4 & 0 & $7.5 \mathrm{YR} 5 / 8$ \\
\hline Jurien & WJR2c & WJR2a 0.49 & 6 or 4 & 0 & $10 Y R 7 / 6-8$ \\
\hline \multirow[t]{3}{*}{ Cervantes } & WCP2e; & WCP1x;3x & Post 11 & 0 & 10YR 7/8 \\
\hline & WCP4e; & & Pre $1-4-2$ & 0 & 10YR 7/8 \\
\hline & WCP5e & & & 38 & 10YR 7.5/6-8 \\
\hline Lancelin & WLN1a & Continental dune & $4-2$ & 0 & 10YR 7/6-8 \\
\hline Lancelin & WLN2b & WLN2a & $4-2$ & & 10YR $6.5 / 8$ \\
\hline \multirow[t]{2}{*}{ Lancelin } & WLN3a, & WLN3a & Post $11 ?$ & 55 & 10YR 7.5/4 \\
\hline & WLN3e & WLN3e & Pre 1 & 0 & 10YR 7/8 \\
\hline Kalgoorlei & KAL1 & Continental dune & & 0 & 10YR $6.5 / 8$ \\
\hline Guilderton & PGU1b & PGUla & Post 11 & 0 & 10YR $6.5 / 6$ \\
\hline Mt Eliza & PEZ3b & PEZla & Post $11-13$ & 2 & 10YR 7/8 \\
\hline \multirow{2}{*}{$\begin{array}{l}\text { Fairbridge Bluff, Rottnest I } \\
\text { (Rotto) }\end{array}$} & RFB1b; & RFB1a & Post 5e & 13 & $10 Y R$ 8-7/4 \\
\hline & RFB1d & & Pre 1 & & 10YR $7.5 / 3-4$ \\
\hline \multirow[t]{2}{*}{ Mary Cove, Rotto } & RMB2d; & & Post $5 \mathrm{e}-6 ?$ & 38 & $10 Y R 6 / 3$ \\
\hline & $\mathrm{RMC} 1 \mathrm{~b}$ & & & & $10 \mathrm{YR} 7 / 3$ \\
\hline Mimim Cove, Rotto & PMCle & PMClad & Post $5 \mathrm{e}$ & 0 & 7.5YR $6.5 / 6-8$ \\
\hline Jeannie's, Rotto & RJL2b & RJL2a 0.37 & Post $5 \mathrm{e}$ & 45 & $7.5 Y R 6.5 / 4$ \\
\hline Mandurah Q & WMQ1a & Continental dune & $4-2$ & 0 & 10YR 7.5/4 \\
\hline Tims Thicket & PTT2d & PTT1a & Post $5 \mathrm{e}$ & 4 & $10 \mathrm{YR} 8 / 6$ \\
\hline Mandura Q & WMA1 & Continental dune & Post 11 & 0 & $10 \mathrm{YR} 8 / 8$ \\
\hline Esperance (Esp) Q & EEQ1b & EEQ1a & $4-2$ & 0 & $2.5 \mathrm{Y} 8 / 2 / 3 ? ?$ \\
\hline Twilight Bay, Esp & ETW1b & ETW1a & Post 5e & 0 & $2.5 \mathrm{Y} 7.6 ?$ \\
\hline \multirow[t]{2}{*}{ Nine mile Bch, Esp } & ENI5c & $\mathrm{ENI} 5 \mathrm{a} / \mathrm{b}$ & Post 5 & 0 & 10YR 8-7.5/6 \\
\hline & & ENI5d & Pre 1 & & \\
\hline Nine mile Bch, Esp & ENI3b & ENI3a & Post 5e-Pre 1 & 24 & 10YR 6/4 \\
\hline Foul Bay & MFU2e & MFU2 & Post $5 \mathrm{e}$ & 5 & 7.5YR 7/4 \\
\hline Cozy Corner & CCR1d & CCRlc & Post 5e-Pre 1 & 0 & 10YR 5.5/6 \\
\hline QB Quarry & QBY2d & QBY2b & Post 11-Pre 1 & 5 & 7.5YR 5.5/6 \\
\hline Blossom Bch & $\mathrm{ABB} 2 \mathrm{a}$ & $\mathrm{ABB} 2 \mathrm{a}$ & Pre $7 / 9$ & 0 & $7.5 \mathrm{YR} 6-5 / 8$ \\
\hline \multirow[t]{2}{*}{ Ankatel N Perth } & WAN1b(1) & Continental dune & $4-2$ & 0 & $2.5 \mathrm{Y} 7 / 2-3$ \\
\hline & WAN1b(2) & Continental dune & $4-2$ & 0 & $2.5 \mathrm{Y} 7 / 2-3$ \\
\hline
\end{tabular}

${ }^{\mathrm{a}}$ Marine isotope stage (MIS) correlation of quartz deposits are based on AAR determinations from carbonate deposits in this study.

\section{Geologic and climatic setting}

\subsection{Field area and climatic setting}

The study area extends over several thousand kilometers of coastal WA from Esperance to Broome (Fig. 1) covering over $16^{\circ}\left(34-18^{\circ}\right.$ South) of latitude. Climate ranges south to north from cool temperate to tropical, and seasonally wet to extremely hot, windy, and dry. The mean annual temperature varies from about $17^{\circ} \mathrm{C}$ (mean minimum and maximum annual $14-19.7^{\circ} \mathrm{C}$ ) at Cape Leeuwin to $27^{\circ} \mathrm{C}$ (mean minimum and maximum annual $21-33^{\circ} \mathrm{C}$ ) at Cape Range, while rainfall across the same gradient ranges from $600-1000$ to $100-200 \mathrm{~mm} / \mathrm{yr}$ (Australia Bureau of Meterology: www.bom.gov.au). Evaporation rates from south to north are about $1200 \mathrm{~mm} / \mathrm{yr}$ at Cape Leeuwin to over $3000 \mathrm{~mm} / \mathrm{yr}$ at Cape Range. 


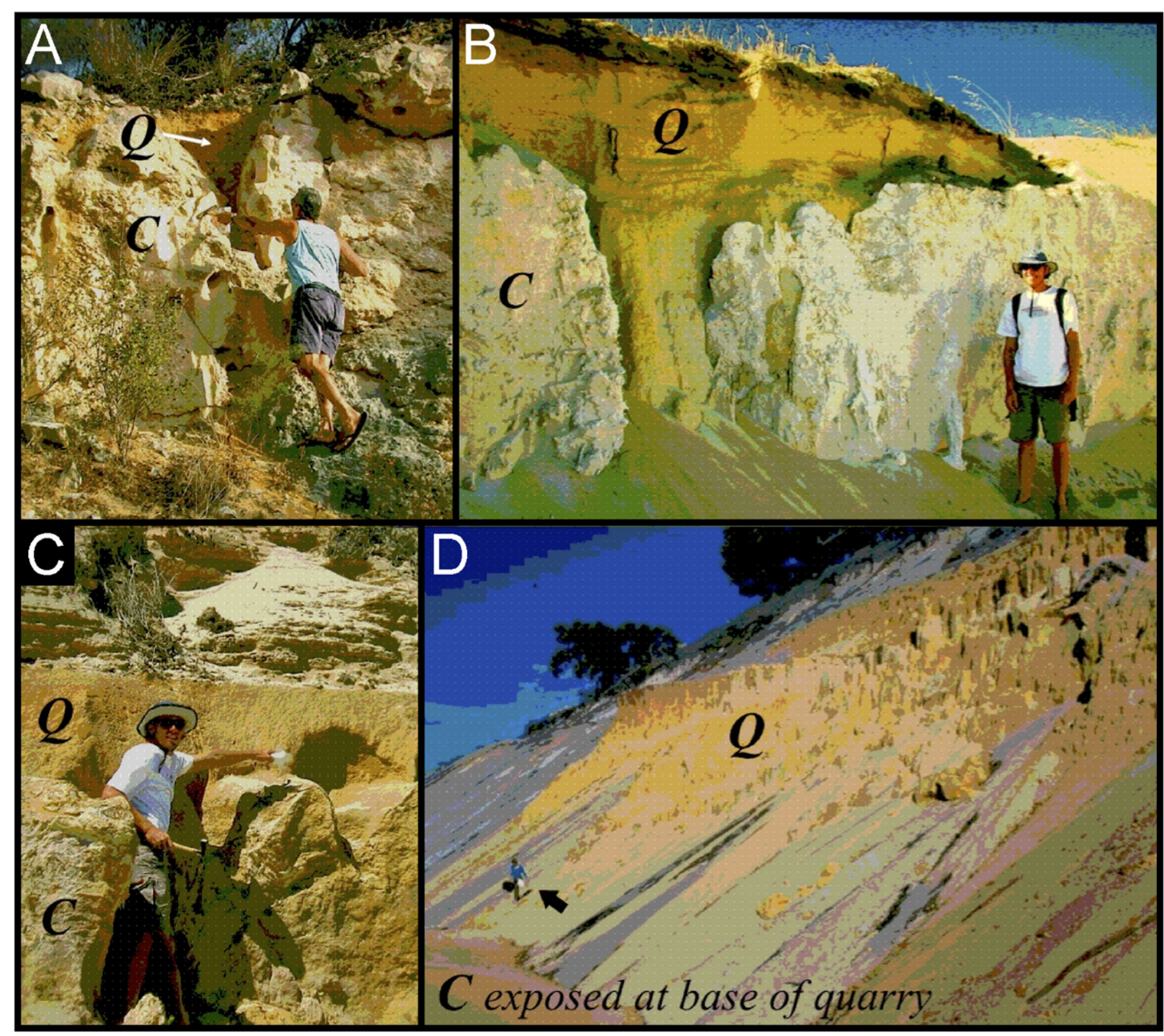

Fig. 3. Pure quartz ("Q") deposits in pits in carbonate dunes ("C") near Lancelin (WLN2 (A)), lenses and pits at Esperance quarry (EEQ1 (B)), extensive meter-thick beds at Nine Mile Beach in Esperance (ENI3b (C)), and 30-m-high quartz dunes at Mandurah Quarry (WMQ1 (D)), which produced Aminozone $G / H$ values on eolianite at its base. Large quartz dunes (like (D)) of middle and late Pleistocene age (Table 2) are found at many localities along the coastal plain of SW WA.

The abundance of Quaternary eolianites in WA is largely dictated by high shelf productivity (warm waters: Leeuwin Current), general aridity, and persistent and strong prevailing onshore winds. A global inventory of eolianites (Brooke, 2001) indicates that their greatest abundance occurs between $30^{\circ}$ and $40^{\circ}$ north and south latitude. South of $30^{\circ}$ in WA, the climate is seasonal and strongly influenced by deep low-pressure fronts sweeping across the Southern Ocean, with strong prevailing westerly winds, and heavy onshore ocean swell. North of about $25^{\circ} \mathrm{S}$, the patterns reverse with dry easterly continental winds flowing offshore of the Great Sandy Desert creating extremely dry and frequently dusty conditions and fewer eolianites. These continental wind patterns appear to contribute to the sedimentology with greater percentages of quartz and reddened sediments appearing the coastal eolianites.

\subsection{Field stratigraphy and geomorphology}

The Quaternary stratigraphy of WA generally consists of a succession of bioclastic dune and shoreline facies intercalated with or capped by either weak interglacial soils called protosols (Vacher and Hearty, 1989), or yellow to red clay and/or quartz-rich soils or paleosols (i.e., buried soils) (Fig. 4). In the Bahama Islands, Hearty and Kaufman (2000) used the term "couplets" to describe the eolianite-soil pairs, and correlated the former with interglacial highstands, and the latter with lowstand events, 


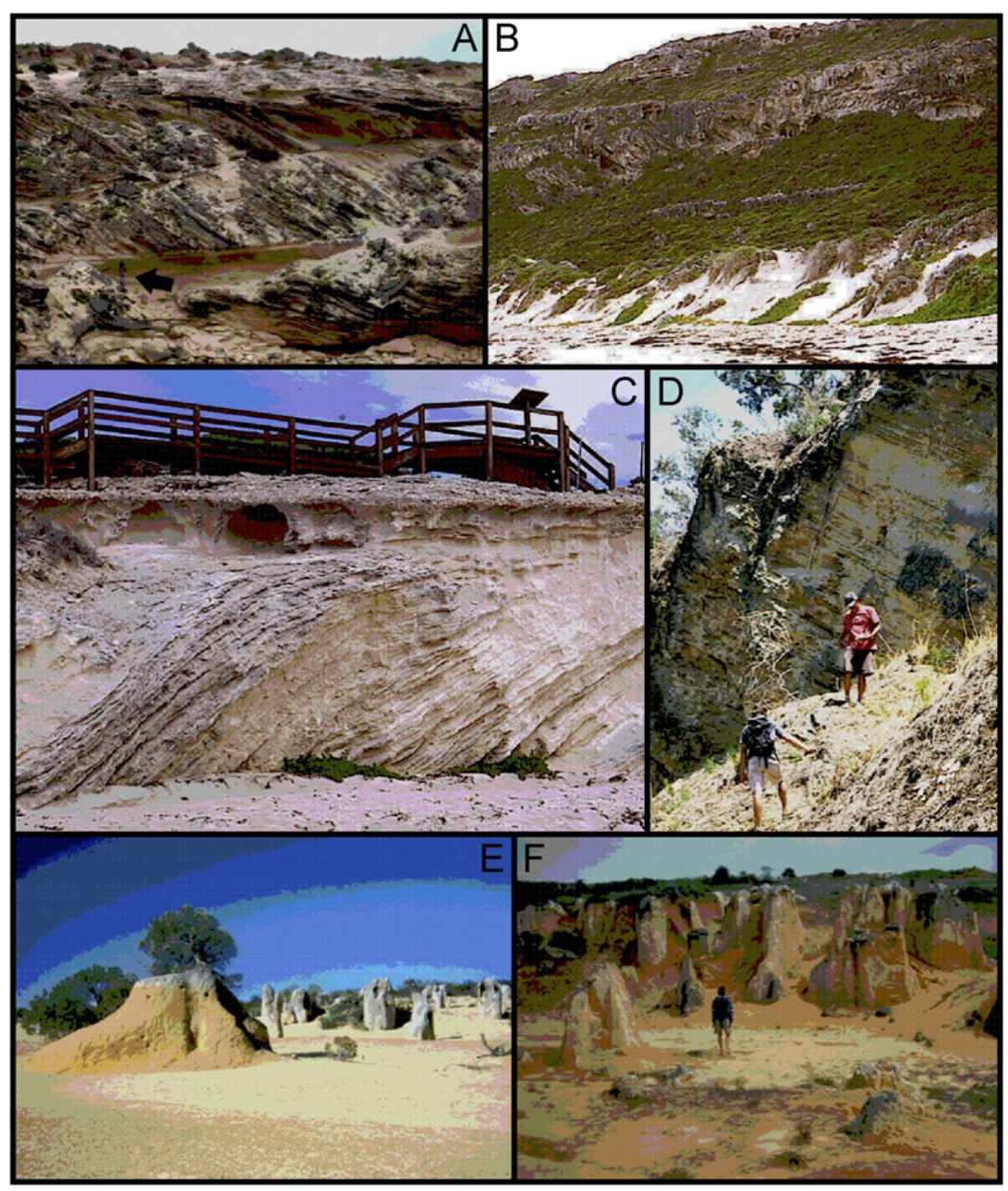

Fig. 4. Montage of typical late and middle Pleistocene eolianites from WA: (A) Succession of late Pleistocene eolianites and weak paleosols at Fish Hook Bay, Rottnest Island (arrow: person for scale). (B) Holocene dunes abutting early Pleistocene eolianites at Conto's Beach south of Margaret River. (C) Late Pleistocene foreset beds at Hamelin Bay south of Margaret River. (D) Middle Pleistocene eolianites in a small quarry above Quarry Bay, Cape Leeuwin. (E) Quartz dunes and "pinnacles" at Nambung National Park. (F) Pinnacles emerging from middle Pleistocene eolianite 5 km east of Guilderton.

when the source shoreline shifted far seaward from the modern coastline.

Most of the WA eolianites consist of weakly to moderately cemented, fine-to-coarse carbonate sand displaying large-scale festoon and planar cross-bedding, generally on windward and leeward flanks, respectively (Fig. 2). Microscopic examination reveals the primary bioclastic components in eolianites (and WR AAE samples) to be mollusks, calcareous red algae, foraminifera, and echinoderms (Kendrick et al., 1991; Kinna, 2002). Most taxa are warm-water species with a similar biogeographic distribution to modern highstand sediment (James et al., 1999), with no biogeographic suggestion of colder, glacial-stage oceanographic conditions on the shelf.

With the exception of a reach of coastline SW of Broome (Hearty et al., 2006), no ooids or oolites are documented from open ocean coastlines of WA (James et al., 2004). However, both Pleistocene and Holocene ooids are abundant in the hypersaline waters near the stromatolite formations (Logan et al., 1970, 1974) deep within Shark Bay.

The primary biogenic grain textures and the original colors of the skeletal organisms are progressively lost with greater age of the limestone, while the progression of $\mathrm{CaCO}_{3}$ recrystallization (aragonite $\rightarrow$ high-Mg calcite $\rightarrow$ low-Mg calcite), secondary mineral precipitation (increasing rock density and hardness), and dissolution and cavernous weathering increase with age (Kindler and Hearty, 1996; Hearty et al., 1996, 2005a; Hearty, 1998). The amino acid concentration is progressively decreased with advancing age and state of diagenesis of the carbonate medium (Roof, 1997; this study). Soils capping limestone deposits increase in richness, hue and chroma (yellows and browns to reddish brown and red) with greater age (Hearty and Kindler, 1997; Hearty, 1998; Hearty et al., 2005a). Diagenetic "grades" I (unconsolidated carbonate sand) to V (recrystallized limestone), defined by Land et al. (1967) for a succession of Bermuda limestones, are appended here as they relate to the Quaternary of WA (Fig. 5). 


\section{Approach and methods}

\subsection{Overview}

To address many of the observations and issues presented above, an extensive survey of coastal eolianites and quartz deposits was undertaken in WA since 2001. Sites were examined and samples collected, and various analyses were made to determine the composition and

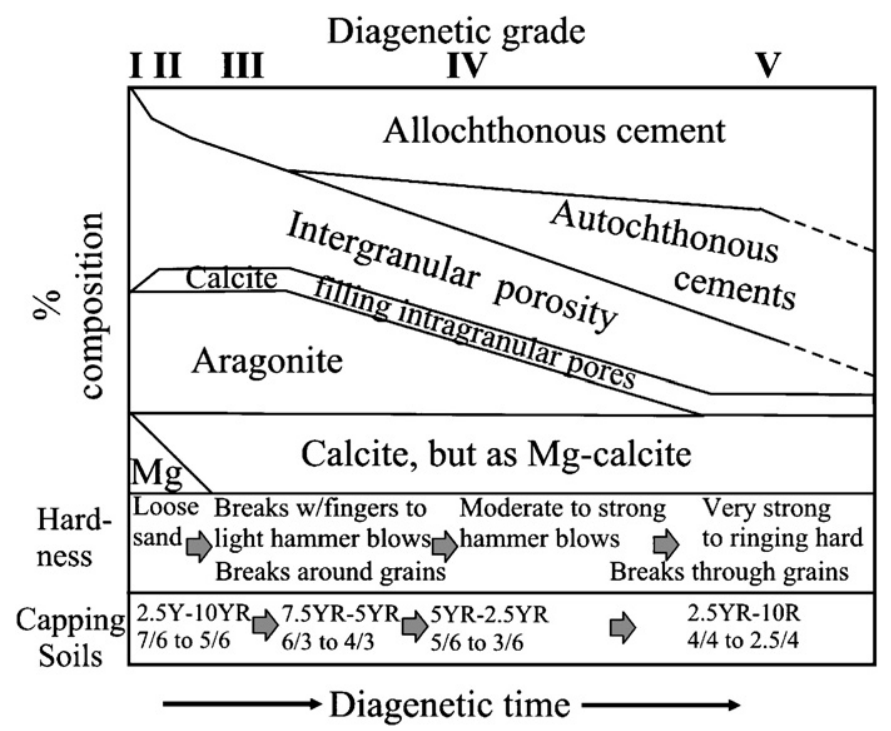

Fig. 5. Mineralogical, thin-section, and relative-age characteristics (rock hardness and Munsell (2002) soil color) defining diagenetic grades from a succession of Holocene (grade I) to early Pleistocene (grade V) carbonates from Bermuda (Land et al., 1967; this study). A large majority of eolianite outcrops along the WA coastline are diagenetic grades I-III. Grades IV and $\mathrm{V}$ characteristics are rarely observed along the coastal plain. possible ages of the deposits. The findings of a regional aminostratigraphic investigation are summarized here, and comparisons are made with other tectonically stable carbonate-producing Quaternary shoreline and AAE sequences of the world.

At each site, stratigraphic sections were logged and photographed. Site locations were assigned names based on the nearest topographic landmark on either 1:100 000 or 1:250 000 map sheets. Samples from over 200 sites were examined and analyzed during our field investigations. These sites are too numerous for plotting in Fig. 1, but GPS coordinates are provided for most sites (Table A1). Those few sites lacking GPS coordinates can be located by place names on topographic sheets of the region. With the exception of the widespread Holocene and modern dunes, nearly all indurated eolianite outcrops encountered along most road cuttings and 4-wheel-drive accessible coastal exposures were described and sampled. We thus consider our collection of sites to be a reasonably comprehensive and unbiased survey of Quaternary exposures in the region. Included among these sites are two localities along the Zuytdorp Cliffs, including Playford's type section at Woomerangee Hill and another north of Tamala station called "Monkey Tarra".

\subsection{Atmospheric and marine reservoir effects on ${ }^{14} C$ ages}

AMS ${ }^{14} \mathrm{C}$ ages were determined on fossil Bothriembryon shells and carbonate sediment samples (Table 3) at the Lucas Heights facility near Sydney, Australia. Both sample materials were prepared in the same manner as AAE samples (below). Radiocarbon ages were calculated based on percent modern carbon with reference to $\delta^{13} \mathrm{C}$ normalized to

Table 3

AMS ${ }^{14} \mathrm{C}$ ages and amino acid ratios of samples analyzed for Bothriembryon land snails, whole rock and charcoal

\begin{tabular}{|c|c|c|c|c|c|c|c|c|c|}
\hline ANSTO lab ID & Field ID & $\delta^{13} \mathrm{C}(\%)$ & ${ }^{14} \mathrm{C}$ age (BP) & $\pm 1 \sigma$ & Calibrated age (cal BP) & $\pm 2 \sigma$ & $A / I$ mean & $A / I \pm 1 \sigma$ & $A / I \mathrm{~N}$ \\
\hline \multicolumn{10}{|c|}{ Bothriembryon land snails } \\
\hline OZG917 & STL3 & -10 & Mod & Mod & Modern & & 0.02 & 0.00 & 2 \\
\hline OZG459 & SMT1(DIO) & -7.4 & 1715 & 40 & 1563 & 138 & 0.05 & 0.02 & 3 \\
\hline OZG460 & SMT4(SIO) & -6.9 & 5645 & 50 & 6370 & 94 & 0.17 & 0.06 & 3 \\
\hline OZG461 & SEB41 & -6.6 & 9380 & 60 & 10,528 & 200 & 0.27 & 0.04 & 4 \\
\hline OZG462 & SBS1as & -3.5 & 3620 & 50 & 3860 & 183 & 0.17 & 0.06 & 5 \\
\hline OZG916 & RCY1b & -6.8 & 31,500 & 280 & Non-finite & & 0.33 & 0.02 & 2 \\
\hline OZG471 & SLL1a & -5.2 & 55,500 & 5600 & Non-finite & & 0.57 & 0.01 & 1 \\
\hline \multicolumn{10}{|c|}{ Carbonate-rich sediment (cements removed) } \\
\hline OZG463 & RFBlz & 0.1 & 2015 & 40 & 1581 & 112 & 0.05 & 0.00 & 2 \\
\hline OZG464 & RAJ1a & 0.5 & 9270 & 70 & 10,093 & 190 & 0.18 & 0.02 & 2 \\
\hline OZG465 & BSM1a(1) & 2.6 & 3515 & 45 & 3401 & 118 & 0.10 & 0.02 & 2 \\
\hline OZG466 & RSP1e & 0.2 & 22,960 & 160 & Non-finite & & 0.22 & 0.01 & 4 \\
\hline OZG467 & RHQ1a(2) & 0.2 & 19,070 & 150 & 22,234 & 333 & 0.23 & 0.02 & 2 \\
\hline OZG468 & SMT1(DIO) & -0.2 & 19,100 & 140 & 22,262 & 263 & 0.42 & 0.04 & 2 \\
\hline OZG469 & SMT4(DIO) & -0.5 & 32,240 & 260 & Non-finite & & 0.72 & 0.02 & 2 \\
\hline \multicolumn{10}{|l|}{ Charcoal } \\
\hline OZG456 & WAN1b(1) & -27.8 & 3430 & 50 & 3615 & 176 & - & - & - \\
\hline
\end{tabular}

Note: Ages were calibrated to calendar years using CALIB v. 5.0.2 and a standard marine reservoir correction for the skeletal sediment (Reimer et al., 2004; Stuvier et al., 1998, 2005). Calibrated ages are reported as median probability and \pm one half of the $2 \sigma$ age range. 
Table 4

$\mathrm{U} / \mathrm{Th}$ ages on coral from Western Australia sites confirming a correlation with MIS 5e

\begin{tabular}{|c|c|c|c|c|c|c|c|c|c|c|c|c|c|}
\hline Site & Location & $\mathrm{U}(\mathrm{ppm})$ & Th (ppt) & $\delta^{234} \mathrm{U}^{\mathrm{a}}$ & $\pm 2 \sigma$ & ${ }^{230} \mathrm{Th} /{ }^{238} \mathrm{U}^{\mathrm{b}}$ & $\pm 2 \sigma$ & ${ }^{232} \mathrm{Th} /{ }^{230} \mathrm{Th}$ & $\operatorname{Age}(\mathrm{ka})^{\mathrm{c}}$ & $\pm 2 \sigma$ & Initial $\delta^{234} U^{d}$ & $\pm 2 \sigma$ & $\operatorname{Ref}^{\mathrm{e}}$ \\
\hline \multicolumn{14}{|c|}{ Margaret River } \\
\hline MFU1a & Foul Bay & 3.19 & 36.96 & 118.58 & 0.83 & 0.7124 & 0.0020 & 3212 & 107.42 & 0.42 & 160.79 & 1.05 & 1 \\
\hline CMP1 & Cowaramup & 3.10 & 38.30 & 108.38 & 0.47 & 0.7591 & 0.0033 & 4380 & 122.05 & 0.97 & 153.19 & 0.74 & 1 \\
\hline \multicolumn{14}{|c|}{ Cape Burney } \\
\hline GCB2 & Cape Burney & 2.76 & 34.52 & 104.63 & 1.60 & 0.7738 & 0.0036 & 52810 & 127.30 & 1.10 & 150.10 & 2.10 & 1 \\
\hline \multicolumn{14}{|c|}{ Shark Bay } \\
\hline SBA1 & Baba Head & 2.81 & 34.79 & 107.07 & 1.10 & 0.7601 & 0.0018 & 3427 & 122.64 & 0.56 & 151.59 & 1.47 & 2 \\
\hline STG5 & Tetradon Loop & 2.88 & 35.94 & 103.81 & 1.30 & 0.7720 & 0.0032 & 14,766 & 127.00 & 1.00 & 148.80 & 1.75 & 2 \\
\hline STG1 & Tetradon Loop & 2.46 & 31.09 & 106.57 & 0.66 & 0.7801 & 0.0030 & 72,614 & 128.80 & 0.92 & 153.50 & 0.96 & 2 \\
\hline STG4 & Tetradon Loop & 1.99 & 24.70 & 105.73 & 1.14 & 0.7683 & 0.0025 & 39,536 & 125.40 & 0.76 & 150.80 & 1.50 & 2 \\
\hline SPI4 & Pelican Island & 2.92 & 35.93 & 107.96 & 1.05 & 0.7612 & 0.0022 & 23,948 & 122.80 & 0.65 & 152.90 & 1.40 & 2 \\
\hline SPI5 & Pelican Island & 2.36 & 28.64 & 107.80 & 0.88 & 0.7500 & 0.0019 & 9177 & 119.60 & 0.58 & 151.30 & 1.15 & 2 \\
\hline SGN1 & Gladstone N & 2.76 & 35.47 & 113.75 & 1.05 & 0.7942 & 0.0023 & 90,678 & 131.30 & 0.79 & 165.20 & 1.40 & 2 \\
\hline SGN3 & Gladstone N & 3.25 & 41.08 & 116.18 & 0.72 & 0.7816 & 0.0015 & 18,740 & 126.87 & 0.47 & 166.40 & 0.96 & 2 \\
\hline SMM3a & Monkey Mia & 2.28 & 28.43 & 109.06 & 0.97 & 0.7717 & 0.0024 & 5347 & 125.60 & 0.75 & 155.70 & 1.30 & 2 \\
\hline SMM4 & Monkey Mia & 3.79 & 46.69 & 106.04 & 0.57 & 0.7603 & 0.0016 & 61 & 122.94 & 0.46 & 150.20 & 0.77 & 2 \\
\hline \multicolumn{14}{|c|}{ Cape Cuvier } \\
\hline LCC9a & Cape Cuvier & 1.24 & 15.67 & 108.68 & 0.70 & 0.7787 & 0.0022 & 4938 & 127.80 & 0.69 & 156.13 & 0.93 & 3 \\
\hline LCC9b & Cape Cuvier & 2.93 & 36.75 & 107.97 & 0.93 & 0.7748 & 0.0039 & 10,949 & 126.80 & 1.22 & 154.68 & 1.31 & 3 \\
\hline $\mathrm{LCC} 9 \mathrm{c}$ & Cape Cuvier & 1.43 & 18.40 & 107.44 & 0.54 & 0.7948 & 0.0040 & 10,814 & 133.15 & 1.25 & 156.71 & 0.85 & 3 \\
\hline LCC9d & Cape Cuvier & 2.67 & 33.17 & 104.93 & 2.40 & 0.7672 & 0.0080 & 6282 & 125.24 & 2.41 & 149.66 & 3.20 & 3 \\
\hline \multicolumn{14}{|c|}{ Cape Range-Ningaloo } \\
\hline NJZ1 & Jacobesz & 2.02 & 25.26 & 108.60 & 1.22 & 0.7675 & 0.0022 & 929 & 124.47 & 0.70 & 154.55 & 1.580 & 3,4 \\
\hline NJZ2 & Jacobesz & 2.14 & 26.58 & 108.52 & 0.81 & 0.7653 & 0.0020 & 6291 & 123.84 & 0.61 & 154.16 & 1.040 & 3,4 \\
\hline NYCla & Yardie Creek & 2.32 & 28.94 & 103.67 & 1.55 & 0.7678 & 0.0021 & 8483 & 125.74 & 0.76 & 148.07 & 2.020 & 1 \\
\hline NYC1b & Yardie Creek & 2.45 & 33.59 & 111.65 & 1.19 & 0.8433 & 0.0020 & 22 & 148.48 & 0.84 & 170.09 & 1.640 & 1 \\
\hline
\end{tabular}

Note: Additional ages from several calibration sites are available in Stirling et al. (1995, 1998). Ages in bold represent strictly reliable ages (see text).

${ }^{\mathrm{a}} \delta^{234} \mathrm{U}=\left\{\left[\left({ }^{234} \mathrm{U} /{ }^{238} \mathrm{U}\right) /\left({ }^{234} \mathrm{U} /{ }^{238} \mathrm{U}\right) \mathrm{eq}\right]-1\right\} \times 10^{3} .\left({ }^{234} \mathrm{U} /{ }^{238} \mathrm{U}\right)$ eq is the atomic ratio at secular equilibrium and is equal to $\lambda_{238} / \lambda_{234}=5.4891 \times 10^{-5}$, where $\lambda_{238}$ and $\lambda_{234}$ are the decay constants for ${ }^{238} \mathrm{U}$ and ${ }^{234} \mathrm{U}$, respectively, adopting half-lives of Cheng et al. (2000).

${ }^{\mathrm{b}}\left[{ }^{230} \mathrm{Th} /{ }^{238} \mathrm{U}\right]_{\mathrm{act}}=\left({ }^{230} \mathrm{Th} /{ }^{238} \mathrm{U}\right) /\left(\lambda^{238} / \lambda^{230}\right)$.

${ }^{\mathrm{c}} \mathrm{U} / \mathrm{Th}$; Table 4 ages are calculated iteratively using: $1-\left[{ }^{230} \mathrm{Th} /{ }^{238} \mathrm{U}\right]_{\text {act }}=\exp { }_{230} \lambda-\left(\delta^{234} \mathrm{U}(0) / 1000\right)\left(\lambda_{230} /\left(\lambda_{230}-\lambda_{234}\right)\right)\left(1-\exp \left(\lambda_{234}-\lambda_{230} T\right)\right.$ where $T$ is the age in years and $\lambda_{230}$ is the decay constant for ${ }^{230} \mathrm{Th}$. $\lambda_{238}=1.551 \times 10^{-10} \mathrm{yr}^{-1} ; \lambda_{234}=2.826 \times 10^{-6} \mathrm{yr}^{-1} ; \lambda_{230}=9.158 \times 10^{-6} \mathrm{yr}^{-1}$. Strictly reliable ages have ${ }^{234} \mathrm{U}_{\text {initial }} 146.6 \pm 5 \%$.

${ }^{\mathrm{d}}$ The initial value is given by $\delta^{234} \mathrm{U}_{\mathrm{i}}=\delta^{234} \mathrm{U}(0) \exp \left(\lambda_{234} T\right)$, where $T$ is the age in years.

${ }^{\mathrm{e}}$ References: 1 = this study; 2 = O'Leary et al. (in press) Shark Bay; $3=$ O'Leary et al. (in review) Cape Cuvier; $4=$ Hearty et al. (2007).

$-25 \%$. As dune sediments are composed of skeletons of organisms formed in shallow marine waters on the shelf, a marine reservoir age was applied to all AMS ${ }^{14} \mathrm{C}$ ages using CALIB 5.0.2 (Reimer et al., 2004; Stuvier et al., 1998, 2005). We chose the standard reservoir age because, although the evidence from the region is sparse, the ages are not significantly different from $400 \mathrm{yr}$ (calib.qub.ac.uk/marine/ index). All ${ }^{14} \mathrm{C}$ ages were calibrated to calendar years before $1950 \mathrm{AD}$ (cal BP) and reported as median of the probability distribution of the calibrated ages with errors of one-half of the $2 \sigma$ calibrated age range.

We recognize that land snails may carry with them a considerable dead carbon anomaly (100 s to $1000 \mathrm{~s}$ of year) inherited from grazing on radiocarbon-dead limestone (Goodfriend and Stipp, 1983; Goodfriend and Gould, 1996). It is thus possible that several of our shell ages may be somewhat too old, but how much older is difficult or impossible to ascertain. As such, we do not apply a deadcarbon correction. It is encouraging that one live-collected shell sample from Shark Bay (OZG917) was tested and returned a modern $\mathrm{AMS}{ }^{14} \mathrm{C}$ age.

\subsection{U/Th methods}

$\mathrm{U} / \mathrm{Th}$ measurements on corals were performed using a Neptune MC-ICPMS at the Research School of Earth Sciences, Australian National University. Measurements were conducted using a combination of simultaneous multiple-Faraday cup and ion counter protocols. Following the procedures of earlier workers (e.g., Stirling et al., 1995, 1998; McCulloch and Esat, 2000), coral ages (Table 4) were screened for potential $U$ and $T h$ loss or gain based on the following criteria:

1. We consider the calculated $\delta^{234} U_{\text {initial }}$ to be the best quantitative test for open-system behavior in corals. For a coral age to be considered strictly reliable $\delta^{234} \mathrm{U}_{\text {initial }}$ values should reflect a modern seawater value of $146.6 \pm 4 \%$. 
2. The total uranium concentration of fossil corals should approximate modern coral values of about $3 \pm 0.5 \mathrm{ppm}$ of uranium.

3. Fossil corals should be free of allochthonous ${ }^{230} \mathrm{Th}$, as indicated by the absence of detrital ${ }^{232} \mathrm{Th}(<1 \mathrm{ppb})$.

4. Corals should show primary aragonitic structures or have $<2 \%$ calcite concentration.

Primarily strictly reliable coral ages are reported in Table 4; however, several other samples of particular interest with less-reliable ages are also presented. We emphasize that this is not intended to be a study of $\mathrm{U} / \mathrm{Th}$ techniques. We refer to these ages only to confirm that the deposits equate with MIS 5e, and then to provide calibration for mean AAE data from these sites. More detailed investigations of aspects of U/Th geochronology from numerous WA sites are available in Stirling et al. $(1995,1998)$, Hearty et al. (2007), O'Leary et al. (in press, in review), and several forthcoming papers.

\subsection{Amino acid geochronology}

A total of $\sim 500$ samples were analyzed for AAE from three latitudinally defined regions (Fig. 1): Region I-Cape Leeuwin to near Geraldton (34-29 $9^{\circ}$ lat.); Region IIGeraldton to Shark Bay and Cape Cuvier (29-25 S lat.), and Region III-Cape Cuvier to Cape Range and Port Smith near Broome (25-18 ${ }^{\circ} \mathrm{S}$ lat.). Sedimentological analyses of many of the samples were conducted by Honours and Ph.D. students from the James Cook University (Townville, Queensland) including Kinna (2002; biogenic carbonates), Allayialis (2003; quartz deposits), Donald (2003; Shark Bay stratigraphy and sedimentology), and O'Leary (2007 and following papers; WA geochronology).

A large database of AAE analysis of WR and the ubiquitous WA land snail Bothriembryon provides the primary device for site-age comparisons across WA. Additional details of the WR sample preparation procedures and protocols are presented in Hearty and Kaufman (2000). Briefly, WR samples were milled and sieved, split into two equal samples, and each prepared and analyzed to assess the analytical uncertainty. Samples were gently disaggregated and sieved to obtain the $250-850 \mu \mathrm{m}$ sand fraction. Previous studies have shown that this size range is typical of beach and dune facies, and tends to exclude fine intergranular cements as well as large grains or shells that could disproportionately influence the sample result. The $A / I$ value is a measure of the extent of epimerization of the common amino acid isoleucine. In living organisms, the $A / I$ value after preparation is initially near zero $(\sim 0.015)$ and increases with age to a ratio of $\sim 1.30$. Several modal classes or "aminozones" of D-alloisoleucine/ L-isoleucine (or $A / I$ ) ratios from both sample materials are calibrated with numerical ages by AMS ${ }^{14} \mathrm{C}$ and $\mathrm{U} / \mathrm{Th}$ ages from this and other studies. Changing thermal histories across the WA climatic gradient from Cape Leeuwin to Cape Range yield different values, such that mean $A / I$ for
Aminozone E in Region I $(\sim 0.30)$ will be lower than Regions II and III $(\sim 0.50$ to $\sim 0.56)$. Correlation of the Aminozone $\mathrm{E}$ across the gradient is accomplished by independent $\mathrm{U} / \mathrm{Th}$ ages on corals. All AAE analyses were performed at the Amino Acid Laboratory of Northern Arizona University (D. Kaufman, Director) following the standard protocols of Miller and Brigham-Grette (1989).

As the WR method analyzes aggregates of skeletal grains that form over time, entirely "modern" ratios are not expected. For example, modern beach sand from near Fairbridge Bluff on Rottnest Island yields an AMS ${ }^{14} \mathrm{C}$ age of $1581 \pm 112 \mathrm{cal} \mathrm{BP}$ and a mean $A / I$ of $0.049 \pm 0.000$ (2) (Table 4 and Table A1). This sample presumably includes a mix of sand grains from late Holocene to modern age. Mixing of intraclasts from older interglacial deposits may occur in some cases, but as the concentration of amino acids decreases exponentially with age, limited percentages of reworked grains do not yield sufficient concentration of amino acids to significantly alter the $A / I$ value (Hearty and Kaufman, 2000). In contrast, however, the mixing of carbon-dead grains into younger deposits has a profound effect on ${ }^{14} \mathrm{C}$ ages, which can be independently assessed by AAE as will be demonstrated below.

Three to eight Bothriembryon shells were analyzed and averaged from a total of about 40 stratigraphic levels. Bothriembryon are abundant in most stratigraphic units around Shark Bay, and more sparsely in the adjacent Zuytdorp Cliffs. In all cases, the shells were sub-sampled from the same area of the apertural lip. This taxon demonstrates moderately variable AAE results compared to other land snails, possibly due to the more open microstructure of the fossil shells.

\subsection{Amino acid diagenesis: loss of amino acids with age}

Previous studies have determined that amino acid concentration decreases exponentially with greater sample age (Hearty and Kaufman, 2000; Hearty et al., 2004a). If fossil or WR sediment samples are generally well preserved, and there is no evidence for unusual diagenesis (such as associated cavernous weathering, extreme Fe staining, complete recrystallization), then there is a threshold age at which samples yield insufficient levels of amino acids to be accurately measured. "Insufficient levels" translates to detection at the level of hundreds of picomoles with the ion exchange technique. A demonstrated effect of diagenesis and leaching is the selective loss of D-alloisoleucine (" $A$ " of $A / I)$, relative to L-isoleucine, resulting in decreasing $A / I$ in the most altered samples (Roof, 1997). For this reason the maximum $A / I$ values of a set of several from a single stratigraphic level are considered to be the most reliable indication of the deposit age. The terminal condition of the samples is the complete loss of amino acids (non-detectable on the HPLC), typically in the oldest recrystallized samples. As will be examined below, we suggest this progression is time dependent, and can thus be used as a relative-age indicator within restricted climate regimes. 


\section{Results}

\subsection{Regional aminostratigraphy of coastal eolianites and} marine deposits in $W A$

The primary objective of this study is to provide an independent assessment of the frequency of occurrence (the number of sites yielding similar ages) and the range of ages of eolianite deposits along the coastal zone of WA. This study does not attempt to provide precise age estimates of individual sites, but only to draw reasonable generalizations on deposit ages (i.e., Holocene, late, middle, or early Pleistocene with the latter two each comprising several interglacials) from WR and land snail $A / I$ data across the three regions delineated in Fig. 1.

\subsection{Aminozones $A-H$ from $W R$ and Bothriembryon samples}

WR histograms defined from Regions I-III show the frequency and distribution of mean $A / I$ values for both
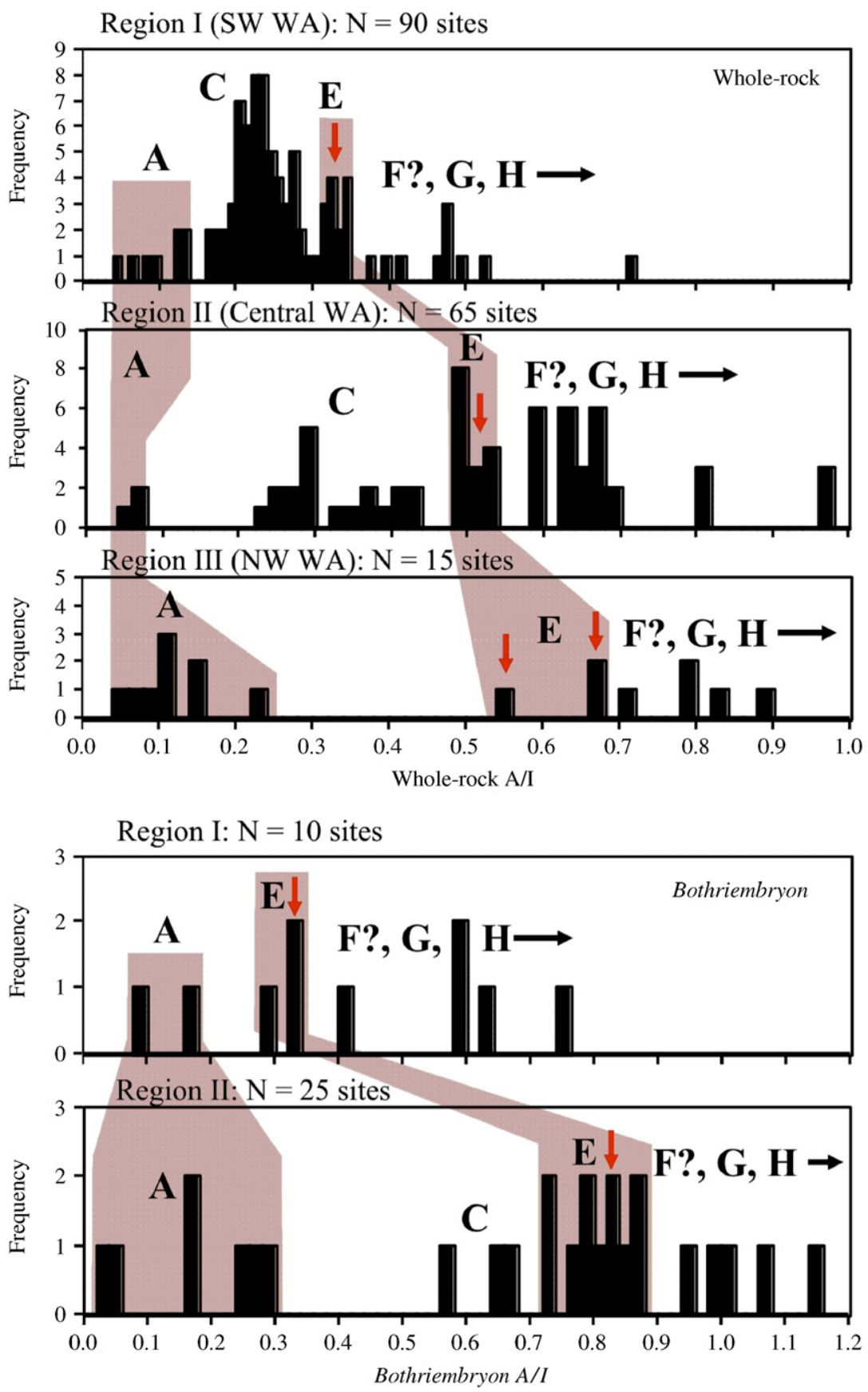

Fig. 6. Histograms of whole-rock (WR) and Bothriembryon $A / I$ values in SW West Australia south of $29^{\circ}$ latitude (Region I), central 29-25 latitude (Region II), and NW 25-18 latitude (Region III). The influence of warmer climate history to the north is indicated by higher calibrated mean WR $A / I$ from U/Th calibration sites (arrows) across the region (Table 4; Stirling et al., 1995, 1998). Similar regional patterns are revealed in dunes and soils containing Bothriembryon land snails. 
Table 5

Aminostratigraphy of Regions I and II of Western Australia (WA) determined in this study

\begin{tabular}{|c|c|c|c|c|c|}
\hline Amino-zone & $\begin{array}{l}\text { Region I: Perth (P) } \\
\text { Rottnest (R) }\end{array}$ & $\begin{array}{l}\text { Representative locality } \\
\text { SW WA }\end{array}$ & $\begin{array}{l}\text { Region II Shark Bay } \\
\text { and Zuytdorp Cliffs }\end{array}$ & $\begin{array}{l}\text { Representative locality } \\
\text { (Shark Bay area) }\end{array}$ & MIS correlation \\
\hline A3 & $\begin{array}{l}0.05(1) \\
0.11 \pm 0.02(15)\end{array}$ & $\begin{array}{l}\text { R: Salmon Bay } \\
\text { R: Army Jetty; } \\
\text { Herschell Q }\end{array}$ & $\begin{array}{l}0.06 \pm 0.01(3) \\
0.28 \pm 0.02(6)\end{array}$ & $\begin{array}{l}\text { Hamelin Pool } \\
\text { Unit 1, Eagle Lookout, }\end{array}$ & Modern to mid 1 \\
\hline $\mathrm{A} 1 / \mathrm{C} ?$ & $0.21 \pm 0.03(8)$ & R: South Point & & Goulet Bluff & Early 1 or reworked $\mathrm{C}$ \\
\hline $\mathrm{C} / \mathrm{D}$ & $0.23 \pm 0.03(74)$ & $\begin{array}{l}\text { R: South Point and } \\
\text { Fish Hook Bay }\end{array}$ & $0.41 \pm 0.01(2)$ & Unit k, Eagle Lookout & $5 a / 5 c$ \\
\hline $\begin{array}{l}\mathrm{E} 2 \sim 125 \mathrm{ka} \\
\mathrm{E} 1\end{array}$ & $0.32 \pm 0.04(42)$ & $\begin{array}{l}\text { P: Minim Cove } \\
\text { R: Fairbridge Bluff }\end{array}$ & $\begin{array}{l}0.50 \pm 0.02(8) \\
0.62 \pm 0.03(5)\end{array}$ & $\begin{array}{l}\text { Baba Head } \\
\text { Gladstone N. }\end{array}$ & $5 e$ \\
\hline $\mathrm{F} ? / \mathrm{G}$ & $0.41 \pm 0.01(4)$ & P: Peppermint Grove & $0.67 \pm 0.01(3)$ & & $7 / 9 ?$ \\
\hline \multirow[t]{2}{*}{$\mathrm{H}$} & $\begin{array}{l}0.49 \pm 0.04(6) \\
0.52 \pm 0.02(2)\end{array}$ & $\begin{array}{l}\text { P: Fremantle Fort } \\
\text { Guilderton Q. }\end{array}$ & $0.97 \pm 0.01(2)$ & $\begin{array}{l}\text { Baba Head yellow } \\
\text { oolite }\end{array}$ & 11 \\
\hline & $0.72 \pm 0.02(1)$ & $\begin{array}{l}\text { Cape Leeuwin: } \\
\text { Quarry Bay high } \\
\text { eolianite in Q }\end{array}$ & & & \\
\hline BRS & & & & $\begin{array}{l}\text { Base of Cape Peron } \\
\text { sections? }\end{array}$ & $12-24 ?$ \\
\hline K & $>780 \mathrm{ka} \mathrm{ND}$ & $\begin{array}{l}\text { Leeuwin-Naturaliste } \\
\text { ridge }\end{array}$ & Low $A / I$ to ND & Zuytdorp Cliffs & $25-37 ?$ \\
\hline
\end{tabular}

$\mathrm{ND}=$ non-detectable. BRS $=$ Big red soil (see text). Numerical values are D-alloisoleucine $/ \mathrm{L}$-isoleucine $(A / I)$ values $(\mathrm{mean}, \pm 1 \sigma,(N=$ number of samples or sites)) from whole rock limestone samples. Ratios from equal-age sites increase with warmer climate history: SW WA coolest and NW WA warmest.

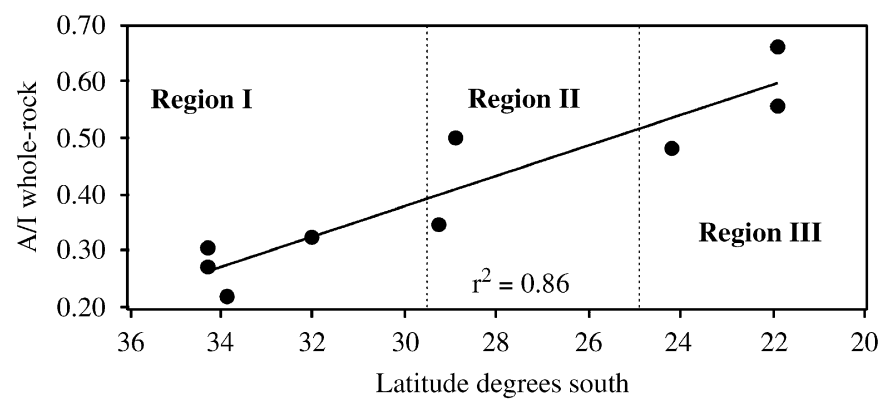

Fig. 7. Gradient of MIS 5e whole rock $A / I$ values from $\mathrm{U} /$ Th-dated coral sites across coastal Western Australia. U/Th ages are from Table 4 and Stirling et al. (1995, 1998).

sample materials from $200+$ sites (Table A1; Fig. 6). The Aminozones $\mathrm{A}-\mathrm{H}$ nomenclature, indicated on the tables and histograms, represents modal classes of individual $A / I$ values of increasing age (Table 5), as defined in previously mentioned studies. Aminozone A is correlated with the Holocene (MIS 1) deposits, and verified by ${ }^{14} \mathrm{C}$ analyses (Table 3). Aminozones $\mathrm{C}$ and $\mathrm{E}$ equate with the last interglaciation and encompass MIS 5a through 5e. U/Th ages on corals from cited studies and Table 4 confirm the correlation of Aminozone E with MIS 5e and provide a calibration for $A / I$ means from each region (arrows in Fig. 6). Calibrated MIS 5e (125 ka) $A / I$ values (Fig. 7) increase regionally between Margaret River and Cape Range between latitude $34^{\circ}$ and $20^{\circ}$ South $\left(r^{2}=0.86\right)$.

Older Aminozones F?, G, and $\mathrm{H}$ probably correlate with middle Pleistocene interglacials and marine isotope stages (MIS) 7? to 11 ("F?" and "7?" are queried as we suspect coastal deposits of this age are rarely found above sea level on stable coastlines, as discussed in Hearty, 2002a). As expected, the number of sites associated with older Aminozones $\mathrm{F}$ ? through $\mathrm{H}$ are fewer compared with Aminozones A-E; older deposits are eroded or buried during younger coastal sedimentary events.

WR samples appear to provide regionally consistent $A / I$ data for deposits up to Aminozone H. However, because of the slowing epimerization rate and lower amino acid concentrations, some older middle Pleistocene correlations may be off by plus or minus one interglacial. Beyond Aminozone $\mathrm{H}$, older deposits commonly yield lowered $A / I$ or non-detectable levels of amino acids. For example, a massive eolianite at Mt. Eliza (PEZ1) in King's Park, central Perth, yielded trace to non-detectable levels of amino acids in three of four samples, averaging only $\sim 11.7 \mathrm{nM} / \mathrm{mg}$ $(A+I)$. A measurable but unreliable $A / I$ of 0.188 was determined from the remaining sample with a concentration of only $17.3 \mathrm{nM} / \mathrm{mg}$. Mt. Eliza lies about $3 \mathrm{~km}$ landward of the Peppermint Grove site, which is correlated with MIS 7 or 9 (Murray-Wallace and Kimber, 1989; Hearty, 2003). Based on the 2-4 m higher-than-present sea level indicated by the subtidal-intertidal facies in the deposit, we suggest MIS 9 is the more likely correlation. A thermoluminescence age of $>422 \mathrm{ka}$ (Price et al., 2001) confirms that Mt. Eliza is certainly older than Peppermint Grove and most likely much older than Aminozone H ( 400 ka).

\subsection{Age estimates on WR carbonate sediment and shells using apparent parabolic kinetics ( APK)}

Epimerization kinetics for WR samples generally conforms more closely to a first-order reversible reaction than 
for mollusks (Hearty et al., 1992). Nonetheless, APK can be used to estimate WR deposit ages. As mentioned, U/Th calibration at ca. $125 \pm 5 \mathrm{ka}$ of Aminozone $\mathrm{E} A / I$ values is provided at numerous sites along the WA coastline (Table A1 and Table 4; Fig. 6). Holocene deposits are generally $<10 \mathrm{ka}$, as determined with AMS ${ }^{14} \mathrm{C}$ (Table 3) and low $A / I$ values. The estimated ages of intermediate aminozones (D, C, and B) may be interpolated on the basis of an APK model (Mitterer and Kriausakul, 1989). Ages of aminozones older than E (125 ka) must be extrapolated as few middle or early Pleistocene calibrations are generally available in WA.

APK age estimates, based on $A / I$ at 125 ka per region are based on the equation:

$t=\left[(A / I)_{\mathrm{s}} / m_{\mathrm{c}}\right]^{2}$,

where $m_{\mathrm{c}}$ is the calibrated rate of $\left.\mathrm{AAE}=\left[(A / I)_{\mathrm{c}} / t_{\mathrm{c}}^{1 / 2}\right)\right]$, $(A / I)_{\mathrm{s}}$ the $A / I$ of the sample, and $t$ the time in years.

MIS 5e calibrations (Table 4; Table A1) of WR $A / I$ at $125 \mathrm{ka}$ are: Region I at $0.32 \pm 0.04$ (8) (Foul Bay, Fairbridge Bluff, and Leander Point); Region II at $0.50 \pm 0.03$ (8) (C. Burney and Baba Head); and, Region III at $0.56 \pm 0.07$ (4) (Jacobs Rd). In all cases, WR $A / I$ were determined from the marine sediment matrix enclosing or immediately adjacent to corals used for calibration. From APK, the maximum ages estimated from the highest and most reliable $A / I$ s from Regions I, II, and III consistently range between 300 and $500 \mathrm{ka}$, correlating with several interglacials between MIS 9 through 13 (Table A1; Fig. 6).

\subsection{APK on Bothriembryon land snails}

Land snails contained in dunes immediately overlying MIS 5e marine deposits are assumed to date to latest MIS $5 \mathrm{e}$, and therefore are assigned a slightly younger calibration age of $115 \mathrm{ka}$ is assumed. Bothriembryon are only abundant in Regions I and II, where calibration $A / I \mathrm{~s}$ are $0.34 \pm 0.07(4)$ (Foul Bay, Margaret River) and $0.83 \pm 0.03$ (20) (Eagle Bluff and Lookout, Shark Bay; Fig. 8A), respectively. In previous studies (e.g., Poecilozonites from Bermuda; Hearty et al., 1992, 2004b), empimerization kinetics in land snails generally exhibit parabolic pathways, compared to WR, and appear to do so for Bothriembryon, up to the last interglacial when independent calibration is considered over the past $130 \mathrm{ka}$ (Fig. 8B). The estimated ages of aminozones based on Bothriembryon older than Aminozone E calculated by APK suggest a range of ages up to about $600 \mathrm{ka}$.

The stratigraphy of Shark Bay is well represented by exposures around Eagle Bluff Lookout (SEL and SEB; Fig. 8A). Many of the soils, quartz dunes, and eolianite units contain a mix of $B$. costulatus (Lamarck) and $B$. onslowi (Cox) (G. Kendrick, personal communication, 2005 ) in at least 14 distinct levels, labelled in italics " $a$ " to " $n$ " stratigraphically from the base to the top of the section (Fig. 8A).
A

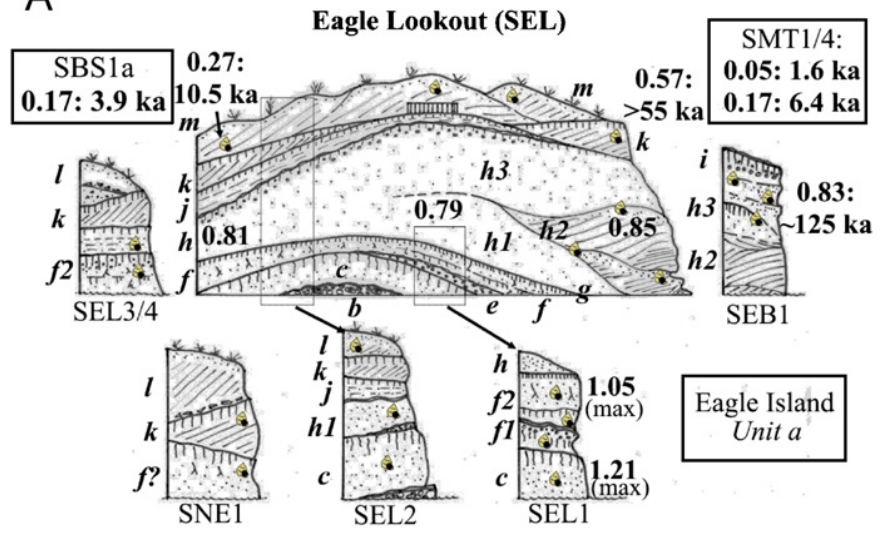

B

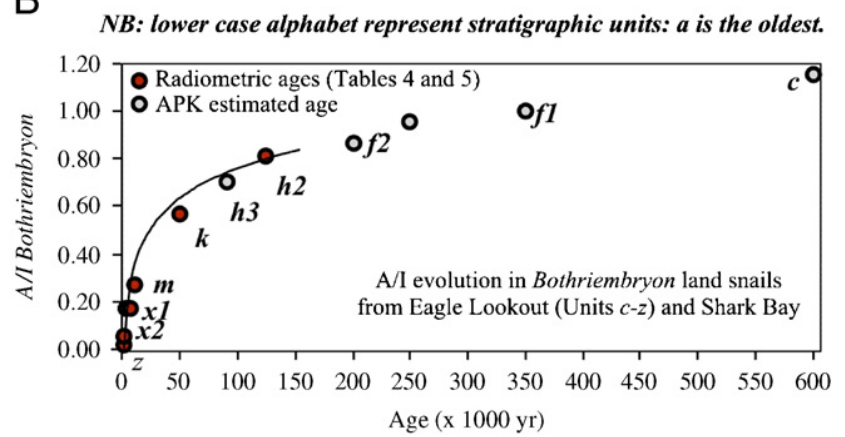

Fig. 8. (A) Litho- and aminostratigraphy from central Shark Bay. Lower case italic alphabet define lithostratigraphic units from the oldest " $a$ " to the youngest " $n$ " in the basin. Average Bothriembryon A/Is from upper units are shown with calibrated AMS ${ }^{14} \mathrm{C}$ ages (from Table 3). A MIS 5e correlated Aminozone E $(\sim 125 \mathrm{ka})$ at Eagle Bluff is based on $A / I$ correlation with nearby Baba Head (Table 4). (B) Approximate parabolic curve showing evolution of $A / I$ in Bothriembryon over the past $130 \mathrm{ka}$ from dated samples. The estimated ages of older units are calculated from the APK model (Mitterer and Kriausakul, 1989).

\subsection{Quantification of loss of amino acids with age: increasing then decreasing $A / I$}

Based primarily on morphostratigraphic and vertical stratigraphic succession, and limited radiometric ages, we independently ranked the relative ages of lithologic units from Shark Bay and the Zuytdorp Cliffs covering the entire depositional interval discussed in this paper. The key sections include Eagle Lookout (SEL, SEB), and Zuytdorp Cliffs (SMT and SWG) and are illustrated mostly in Figs. 8, 10 and 11. At Baba Head (SBA), MIS 5e beach deposits lap directly on to an oolite of middle Pleistocene age. Amino acid concentrations were determined based on a synthetic norleucine spike adjusted to the mass of biogenic carbonate in the samples from representative units of the lithostratigraphic succession (Table 6).

Plots of stratigraphic rank versus amino acid concentration and $A / I$ (Table 6 ) quantify the progressive decrease in amino acid $(A+I)$ concentration for over half of the succession as $A / I$ increases and peaks around 0.95 and 1.20 for WR and Bothriembryon land snails, respectively (Fig. 9). Once the $A / I$ attains an equilibrium value, it then decreases as 
Table 6

Amino acid concentrations in whole-rock samples and Bothriembryon land snails from the Shark Bay/Zuytdorp Cliffs, including stratigraphic rank

\begin{tabular}{|c|c|c|c|c|c|c|c|c|}
\hline \multirow[t]{2}{*}{ Lab ID (UAL) } & \multirow[t]{2}{*}{ Sample ID } & \multirow[t]{2}{*}{ Location } & \multirow[t]{2}{*}{$A / I$} & \multirow[t]{2}{*}{ Age or MIS } & \multicolumn{2}{|c|}{ Concentration (nM/mg) } & \multirow[t]{2}{*}{$A+I$} & \multirow[t]{2}{*}{ Straigraphic rank } \\
\hline & & & & & Ile & aIle & & \\
\hline \multicolumn{9}{|l|}{ Whole rock } \\
\hline $4069 \mathrm{~A}$ & RFB 1z & Fairbridge Bluff & 0.049 & $2010 \pm 40 \mathrm{yr}$ & 384.2 & 18.6 & 402.9 & 21 \\
\hline $4069 \mathrm{~B}$ & RFB 1z & Fairbridge Bluff & 0.050 & 1 & 253.4 & 12.6 & 266.0 & 21 \\
\hline $4073 \mathrm{~A}$ & RAJ 1a & Army Jetty & 0.189 & $9260 \pm 60 \mathrm{yr}$ & 31.6 & 6.0 & 37.6 & 20 \\
\hline $4073 \mathrm{~B}$ & RAJ 1a & Army Jetty & 0.165 & 1 & 77.6 & 12.8 & 90.3 & 20 \\
\hline $4057 \mathrm{~B}$ & SEB 41 & Eagle Bluff N & 0.257 & $2 ?$ & 11.1 & 2.9 & 14.0 & 19 \\
\hline $4066 \mathrm{~A}$ & SMT 1 (D10) & Monkey Tarra & 0.417 & $>19,100 \pm 130 \mathrm{yr}$ & 60.3 & 23.4 & 83.8 & 18 \\
\hline $4121 \mathrm{~A}$ & SEL5k & Eagle Bluff & 0.425 & $2-4$ & 11.8 & 4.8 & 16.6 & 17 \\
\hline $4121 \mathrm{~B}$ & SEL5k & Eagle Bluff & 0.439 & $2-4$ & 16.1 & 7.1 & 23.2 & 16 \\
\hline $4068 \mathrm{~A}$ & SMT 4 (D10) & Monkey Tarra & 0.576 & $>32,250 \pm 260 \mathrm{yr}$ & 38.4 & 27.0 & 65.3 & 15 \\
\hline $3804 \mathrm{~A}$ & SEB1a & Eagle Bluff & 0.466 & $5 e$ & 28.5 & 13.1 & 41.6 & 14 \\
\hline 3804 B & SEBla & Eagle Bluff & 0.509 & $5 e$ & 35.0 & 17.8 & 52.8 & 14 \\
\hline $4129 \mathrm{~A}$ & SBA1d & Baba Head & 0.427 & $122.6 \pm 0.6 \mathrm{ka}$ & 101.5 & 43.3 & 144.8 & 13 \\
\hline $4129 \mathrm{~B}$ & SBA1d & Baba Head & 0.595 & $5 e$ & 79.9 & 47.5 & 127.4 & 13 \\
\hline $4059 \mathrm{~A}$ & SFW 6a & Fowler's Bay Oo & 0.505 & $5 e$ & 14.4 & 6.8 & 21.2 & 12 \\
\hline $4127 \mathrm{~A}$ & SFW5a & Fowler's Bay Oo & 0.632 & $5 \mathrm{e}$ & 5.6 & 3.5 & 9.2 & 12 \\
\hline $4127 \mathrm{~B}$ & SFW5a & Fowler's Bay Oo & 0.565 & $5 e$ & 6.8 & 4.0 & 10.8 & 12 \\
\hline $4058 \mathrm{~A}$ & SFW 2d & Fowler's Bay Sk & 0.580 & $5 e$ & 9.5 & 5.5 & 15.0 & 11 \\
\hline $4058 \mathrm{~B}$ & SFW 2d & Fowler's Bay Sk & 0.693 & $5 e$ & 15.7 & 10.9 & 26.6 & 11 \\
\hline $4130 \mathrm{~A}$ & SBA3b & Old Baba oolite & 0.956 & 9 or 11 & 22.0 & 21.1 & 43.1 & 10 \\
\hline $4130 \mathrm{~B}$ & SBA3b & Old Baba oolite & 0.974 & 9 or 11 & 24.6 & 24.0 & 48.6 & 10 \\
\hline $4130 \mathrm{C}$ & SBA3b & Old Baba oolite & 0.919 & 9 or 11 & 30.7 & 28.2 & 59.0 & 10 \\
\hline $4130 \mathrm{D}$ & SBA3b & Old Baba oolite & 0.924 & 9 or 11 & 29.1 & 26.9 & 56.0 & 10 \\
\hline $3813 \mathrm{~A}$ & PEZ1a(1) & Mt. Eliza, Perth & 0 & $>422 \mathrm{ka}$ & 10.0 & 0.0 & 10.0 & Not ranked \\
\hline $3813 \mathrm{~B}$ & PEZ1a(1) & Mt. Eliza, Perth & 0 & $>422 \mathrm{ka}$ & 8.5 & 0.0 & 8.5 & Not ranked \\
\hline $3814 \mathrm{~A}$ & PEZ2a(2) & Mt. Eliza, Perth & 0 & $>422 \mathrm{ka}$ & 16.5 & 0.0 & 16.5 & Not ranked \\
\hline $3814 \mathrm{~B}$ & PEZ2a(2) & Mt. Eliza, Perth & 0.188 & $>422 \mathrm{ka}$ & 12.5 & 2.4 & 14.9 & Not ranked \\
\hline $4065 \mathrm{~A}$ & SMT 1 (D6) & Monkey Tarra & 0.745 & Unknown & 15.4 & 11.5 & 26.9 & 9 \\
\hline $4065 \mathrm{~B}$ & SMT 1 (D6) & Monkey Tarra & 0.859 & Unknown & 21.3 & 18.3 & 39.7 & 9 \\
\hline $4063 \mathrm{~A}$ & SMT 2 (D6) & Monkey Tarra & 0.670 & Unknown & 11.2 & 7.5 & 18.8 & 8 \\
\hline 4063 B & SMT 2 (D6) & Monkey Tarra & 0.754 & Unknown & 17.9 & 13.5 & 31.5 & 8 \\
\hline $4064 \mathrm{~A}$ & SMT1 (D5) & Monkey Tarra & 0.474 & Unknown & 7.3 & 3.5 & 10.8 & 7 \\
\hline 4064 B & SMT1 (D5) & Monkey Tarra & 0.576 & Unknown & 8.7 & 5.0 & 13.7 & 7 \\
\hline $4062 \mathrm{~A}$ & SMT 2 (D4) & Monkey Tarra & 0.069 & Unknown & 72.7 & 5.1 & 77.8 & 6 \\
\hline $4062 \mathrm{~B}$ & SMT 2 (D4) & Monkey Tarra & 0.090 & Unknown & 59.5 & 5.3 & 64.7 & 6 \\
\hline $4116 \mathrm{~A}$ & SWG1 (D9b) & Woomerangee & 0.456 & Unknown & 4.4 & 2.1 & 6.5 & 5 \\
\hline $4116 \mathrm{~B}$ & SWG1 (D9b) & Woomerangee & 0.508 & Unknown & 8.1 & 4.2 & 12.4 & 5 \\
\hline $4115 \mathrm{~A}$ & SWG1 (D9a) & Woomerangee & 0.152 & Unknown & 12.6 & 2.1 & 14.7 & 4 \\
\hline $4115 \mathrm{~B}$ & SWG1 (D9a) & Woomerangee & 0.220 & Unknown & 10.5 & 2.5 & 13.0 & 4 \\
\hline $4117 \mathrm{~A}$ & SWG1 (D8) & Woomerangee & 0.337 & Unknown & 3.9 & 1.3 & 5.2 & 3 \\
\hline $4117 \mathrm{~B}$ & SWG1 (D8) & Woomerangee & 0.421 & Unknown & 2.9 & 1.2 & 4.1 & 3 \\
\hline $4118 \mathrm{~B}$ & SWG1 (D4) & Woomerangee & 0.079 & Unknown & 24.8 & 2.0 & 26.7 & 2 \\
\hline 4119 A & SWG1 (D3) & Woomerangee & 0.117 & Unknown & 13.1 & 1.5 & 14.6 & 1 \\
\hline $4119 \mathrm{~B}$ & SWG1 (D3) & Woomerangee & 0.098 & Unknown & 13.9 & 1.4 & 15.3 & 1 \\
\hline \multicolumn{9}{|c|}{ Bothriembryon land snail } \\
\hline $4211 \mathrm{~A}$ & STL 3 & Tetradon Loop & 0.020 & Modern ${ }^{14} \mathrm{C}$ & 684.3 & 13.4 & 697.7 & 25 \\
\hline $4037 \mathrm{D}$ & SMT1(D10) & Monkey Tarra & 0.043 & $1563 \pm 138 \mathrm{yr}$ & & & & 24 \\
\hline $3953 \mathrm{E}$ & SBS1a & Brickie’s Q & 0.224 & $3860 \pm 183 \mathrm{yr}$ & 137.0 & 30.7 & 167.7 & 23 \\
\hline $3952 \mathrm{C}$ & SMT4(S10) & Monkey Tarra & 0.147 & $6370 \pm 94 \mathrm{yr}$ & 403.1 & 58.9 & 462.1 & 22 \\
\hline 3962 D & SEB 41 & Eagle Bluff & 0.289 & $10,528 \pm 200 \mathrm{yr}$ & 41.4 & 12.0 & 53.3 & 21 \\
\hline $4053 \mathrm{AB}$ & SLL 1a & Little Lagoon & 0.570 & Non-finite ${ }^{14} \mathrm{C}$ & 104.3 & 59.4 & 163.7 & 20 \\
\hline $4013 \mathrm{C}$ & SMM 2b & Monkey Mia & 0.729 & $5 a ?$ & 66.9 & 49.2 & 116.1 & 19 \\
\hline $4013 \mathrm{~B}$ & SMM 2b & Monkey Mia & 0.735 & $5 a ?$ & 105.2 & 76.7 & 181.8 & 18 \\
\hline $4014 \mathrm{~B}$ & SMM 1c & Monkey Mia & 0.631 & $5 a ?$ & 38.1 & 24.0 & 62.2 & 17 \\
\hline $4014 \mathrm{D}$ & SMM 1c & Monkey Mia & 0.675 & $5 a ?$ & 36.2 & 24.4 & 60.6 & 16 \\
\hline $3955 \mathrm{~A}$ & SEB 1b & Eagle Bluff & 0.812 & $5 e$ & 32.0 & 26.0 & 57.9 & 15 \\
\hline 3955 B & SEB $1 \mathrm{~b}$ & Eagle Bluff & 0.829 & $5 e$ & 10.4 & 8.6 & 19.0 & 14 \\
\hline $3959 \mathrm{D}$ & SEB $4 \mathrm{~h}$ (3) & Eagle Bluff & 0.829 & $5 e$ & 38.3 & 31.7 & 70.0 & 13 \\
\hline 3959 A & SEB $4 \mathrm{~h}$ (3) & Eagle Bluff & 0.988 & $5 e$ & 61.3 & 60.6 & 121.9 & 12 \\
\hline $4011 \mathrm{~A}$ & SEL 1f (2) & Eagle Bluff & 0.951 & $7-9$ & 50.1 & 47.8 & 97.9 & 11 \\
\hline $4011 \mathrm{~B}$ & SEL If (2) & Eagle Bluff & 0.986 & $7-9$ & 30.3 & 29.9 & 60.2 & 10 \\
\hline
\end{tabular}


Table 6 (continued)

\begin{tabular}{|c|c|c|c|c|c|c|c|c|}
\hline \multirow[t]{2}{*}{ Lab ID (UAL) } & \multirow[t]{2}{*}{ Sample ID } & \multirow[t]{2}{*}{ Location } & \multirow[t]{2}{*}{$A / I$} & \multirow[t]{2}{*}{ Age or MIS } & \multicolumn{2}{|c|}{ Concentration (nM/mg) } & \multirow[t]{2}{*}{$A+I$} & \multirow[t]{2}{*}{ Straigraphic rank } \\
\hline & & & & & Ile & aIle & & \\
\hline $4010 \mathrm{~A}$ & SEL 1f (1) & Eagle Bluff & 0.234 & $7-9$ & 50.2 & 11.7 & 61.9 & 9 \\
\hline $4009 \mathrm{D}$ & SEL 1c & Eagle Bluff & 0.907 & $\geqslant 11$ & 22.8 & 20.7 & 43.5 & 8 \\
\hline $4009 \mathrm{~B}$ & SEL 1c & Eagle Bluff & 1.096 & $\geqslant 11$ & 22.0 & 24.1 & 46.1 & 7 \\
\hline $4213 \mathrm{~B}$ & SMM5 & Monkey Mia & 1.163 & $\geqslant 11$ & 160.9 & 187.2 & 348.2 & 6 \\
\hline $4213 \mathrm{~A}$ & SMM4 & Monkey Mia & 1.205 & $\geqslant 11$ & 157.7 & 190.1 & 347.9 & 5 \\
\hline 4140 & STD 2a & Tetradon Loop & 1.009 & $\geqslant 11$ & 20.2 & 20.4 & 40.7 & 4 \\
\hline $4208 \mathrm{~B}$ & STD 1a & Tetradon Loop & 1.110 & $\geqslant 11$ & 23.9 & 26.6 & 50.5 & 3 \\
\hline $3965 \mathrm{C}$ & SMT 2 (S6) & Monkey Tarra & 0.391 & Unknown & 12.0 & 4.7 & 16.7 & 3 \\
\hline $3965 \mathrm{D}$ & SMT 2 (S6) & Monkey Tarra & 0.421 & Unknown & 8.6 & 3.6 & 12.2 & 3 \\
\hline 3965 B & SMT 2 (S6) & Monkey Tarra & 0.732 & Unknown & 36.0 & 26.3 & 62.3 & 3 \\
\hline $3965 \mathrm{~A}$ & SMT 2 (S6) & Monkey Tarra & 0.894 & Unknown & 31.2 & 27.8 & 59.0 & 3 \\
\hline $3965 \mathrm{E}$ & SMT 2 (S6) & Monkey Tarra & 0.932 & Unknown & 28.1 & 26.2 & 54.3 & 3 \\
\hline $3963 \mathrm{E}$ & SMT 1 (D6) & Monkey Tarra & 0.655 & Unknown & 57.6 & 37.7 & 95.4 & 2 \\
\hline 3963 B & SMT 1 (D6) & Monkey Tarra & 0.673 & Unknown & 7.5 & 5.2 & 12.7 & 2 \\
\hline $3963 \mathrm{C}$ & SMT 1 (D6) & Monkey Tarra & 0.867 & Unknown & 34.7 & 30.1 & 64.7 & 2 \\
\hline $3963 \mathrm{D}$ & SMT 1 (D6) & Monkey Tarra & 0.967 & Unknown & 26.6 & 25.7 & 52.3 & 2 \\
\hline $3954 \mathrm{E}$ & SMT 2 (D5) & Monkey Tarra & 0.503 & Unknown & 6.4 & 3.2 & 9.7 & 1 \\
\hline $3954 \mathrm{~A}$ & SMT 2 (D5) & Monkey Tarra & 0.583 & Unknown & 14.0 & 8.1 & 22.1 & 1 \\
\hline $3954 \mathrm{D}$ & SMT 2 (D5) & Monkey Tarra & 0.760 & Unknown & 13.7 & 10.4 & 24.1 & 1 \\
\hline $3954 \mathrm{G}$ & SMT 2 (D5) & Monkey Tarra & 0.772 & Unknown & 37.0 & 28.5 & 65.5 & 1 \\
\hline $3954 \mathrm{C}$ & SMT 2 (D5) & Monkey Tarra & 0.779 & Unknown & 23.5 & 18.3 & 41.8 & 1 \\
\hline $3954 \mathrm{~B}$ & SMT 2 (D5) & Monkey Tarra & 0.875 & Unknown & 13.1 & 11.4 & 24.5 & 1 \\
\hline $3954 \mathrm{~F}$ & SMT 2 (D5) & Monkey Tarra & 0.962 & Unknown & 22.2 & 21.4 & 43.6 & 1 \\
\hline
\end{tabular}

Note: Amino acid concentrations of alloisoleucine (aIle) and isoleucine (Ile) are determined based on an internal synthetic norleucine spike, added during preparation based on mass of biogenic carbonate in the sample. Radiometric ages are listed in the previous tables. Some Rottnest Island/Perth sites are provided for comparison.

concentration drops below about $50-80 \mathrm{nM} / \mathrm{mg}$, after which $A / I$ generally becomes very low or unmeasurable. This progression is consistent between two unrelated sample materials and occurs somewhat earlier in WR samples ( $\sim$ rank 10$)$ compared to land snails ( $\sim$ rank 6$)$ from the same succession (Fig. 9), indicating an effective limit of the method of about $500 \pm 100 \mathrm{ka}$. Therefore, these data support the conclusion that reversal of $A / I$ trends toward lower values, progressing to non-detectable levels, is a reasonable time-dependent measure of relative age of limestone and fossils. This progression maps the diagenesis of amino acids in fossil material and independently confirms the stratigraphic and diagenetic evidence that the Zuytdorp Cliffs are the oldest Quaternary units in the Shark Bay area.

\subsection{Stratigraphy, diagenesis, and constraints on the age $(s)$ at the type locality of Tamala Limestone}

As the type locality of the Tamala Limestone, the eolianite at Zytodorp Cliffs should be representative of Quaternary eolianites across WA in terms of stratigraphy, age, and diagenetic characteristics. Two sections along the Zuytdorp Cliffs (Fig. 10) including the type locality were logged in 2002 and 2003 (Fig. 11). The first $\left(26.69273^{\circ} \times 113.6000^{\circ}\right)$ is locally referred to as "Monkey Tarra" (SMT1/2); the etymology is uncertain, as no geographic names appear on topographic maps near the site. The section is about $55 \mathrm{~m}$ high (Fig. 11). The second is located about $3 \mathrm{~km}$ north of Woomerangee Hill (SWG1/2; $26.8836^{\circ} \times 113.7485^{\circ}$ ), where the $135-\mathrm{m}$-high, is somewhat accessible. We collected samples from over half of the exposed units at each site, below which access was limited. However, we observed, recorded, and photographed the entire section in detail at each site (Fig. 10).

\subsubsection{Stratigraphy of Monkey Tarra (SMT1/2)}

The upper seven units analyzed at SMT, each generally 3-10 $\mathrm{m}$ thick (Fig. 11), are composed of medium to fine, buff-colored, moderately to well-sorted sand with variable kurtosis (Donald, 2003). Carbonate percentages in both eolianites and palaeosols range between $55 \%$ and $89 \%$. The carbonate fraction is consistently composed of marine calcareous algae, benthic foraminifera, echinoderms, and molluscs, while the non-carbonate fraction is predominantly silt to fine quartz sand. The relatively low quartz content of the soils compared to those exposed in the adjacent Shark Bay area may be an indication of the distal and elevated position of the ridge and cliffs from continental eolian sources of quartz. Further, weathering of the predominantly carbonate surface appears to have been curtailed by the subsequent episodes of eolian deposition over multiple sea-level cycles.

Eolian bedforms indicate deposition in a subaerial environment. Bioturbation by vegetation and land animals is probably responsible in cases where bedding is destroyed. Marine bedforms were not observed at either Zuytdorp Cliffs site, but lower units likely to contain marine facies 

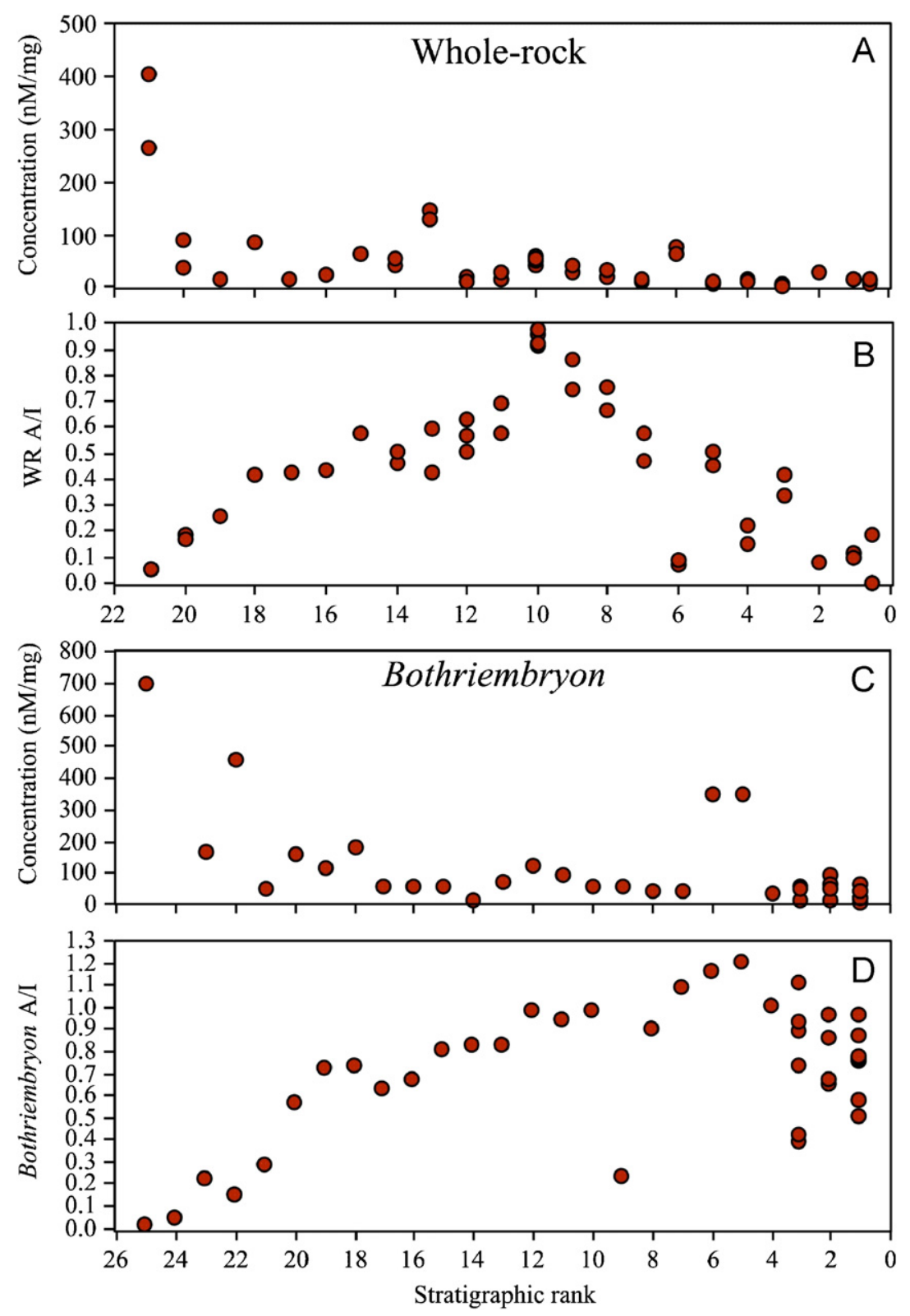

Fig. 9. Amino acid concentration $(A+I$ in $\mathrm{nM} / \mathrm{mg}$ ) and $A / I$ values in selected whole-rock (plates A and $\mathrm{B}$ ) and Bothriembryon (plates $\mathrm{C}$ and $\mathrm{D})$ samples compared to stratigraphic rank. The ranking is based on morphostratigraphic and vertical stratigraphic succession at several key sites in and near Shark Bay. Concentration decreases with older stratigraphic rank of samples, while $A / I$ increases up to 0.95 to $1.10-1.20$ (WR and land snails, respectively), then ultimately decreases to non-detectable levels. This progression of decreasing concentration is time-dependent and can be used under controlled parameters to infer the relative ages of deposits. Units at the Zuydorp Cliffs are represented by stratigraphic rank 9 to 1 for WR and 3 to 1 for land snails.

were not closely observed. The limestone is well cemented in all units except $\mathrm{D} / \mathrm{S} 10$, which comprise recently active dunes in small $<1-2$ ha patches. The stratigraphically highest Pleistocene unit $\mathrm{D} / \mathrm{S} 6$ could be broken with strong hammer blows, while the stratigraphically lowest units collected (D4, S4), were highly indurated, hammer-ringing hard, and difficult to break. The limestone rocks show minor alteration of the grains in the uppermost units. Vugginess and general recrystallization were observed in the rocks of the lower units. The diagenetic grade V (Fig. 5; Land et al., 1967) of the lower limestones suggests the D4 couplet is significantly older and more altered than units higher in the section (grades IV-V).

\subsubsection{Amino acid results from Monkey Tarra (SMT)}

WR samples from eolianites from SMT reveal a decrease in $A / I$ in stratigraphically lower units (Fig. 11). The maximum individual WR ratios of 0.86 and 0.75 (with very low amino acid abundances) from the stratigraphically highest unit D6 suggest a minimum APK age of $300-400 \mathrm{ka}$, or possible correlation with MIS 9 or 11. In successively lower units, mean WR $A / I$ values from units D5 and D4 yield only trace levels of amino acids, and mean $A / I$ of 0.53 and 0.08 , respectively.

On the upper, undulating ridge surface inland of the Zuytdorp Cliffs, Bothriembryon from soils on subactive dunes yield a mean $A / I$ of $0.05 \pm 0.02$ (3) (SMT1(D10)) and 


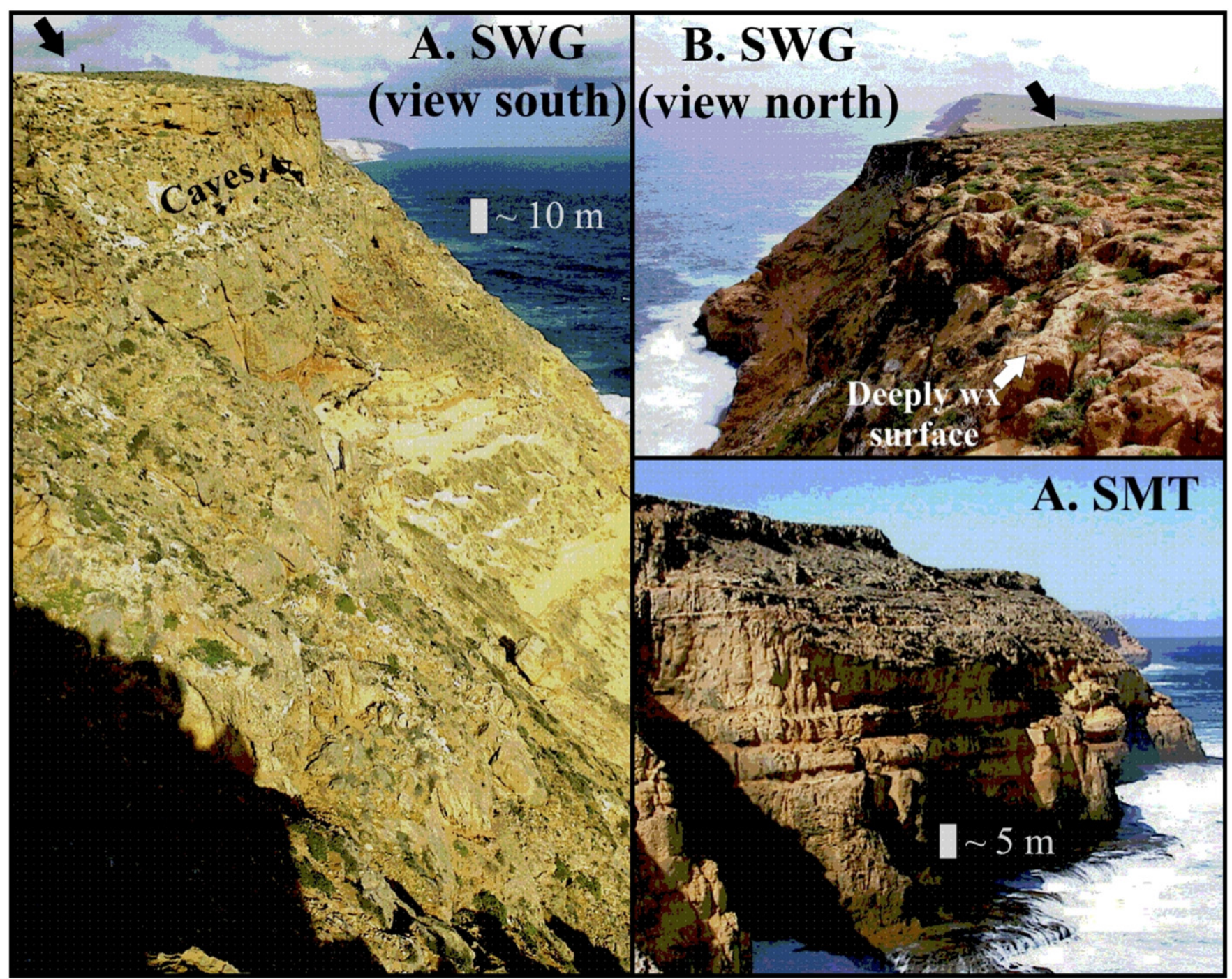

Fig. 10. Images of Zuytdorp Cliffs: (A) View near Playford et al.'s $(1975,1976)$ type locality at Woomerangee Hill (SWG). Arrows identify persons for scale. (B) View near Woomerangee Hill. Note the deep karstic weathering of the surface rocks. (C) Stratigraphy at Monkey Tarra (SMT), located about $20 \mathrm{~km}$ north of Woomerangee along the cliffs.

$0.17 \pm 0.06$ (3) (SMT4(S10)). The $A / I$ values correspond well with calibrated AMS ${ }^{14} \mathrm{C}$ ages of $1563 \pm 138$ and $6370 \pm 94 \mathrm{cal}$ BP from the same individual snails. However, the carbonate sediment enclosing the land snails yields AMS ${ }^{14} \mathrm{C}$ ages of 22,262 \pm 263 and $>32,250$ (infinite) cal BP. Age estimates of 75 and $270 \mathrm{ka}$ were determined by APK from the WR $A / I$ values of 0.38 and 0.72 , suggesting an age well beyond the range of ${ }^{14} \mathrm{C}$ dating. These results indicate that Holocene-age land snails colonized dunes composed of eroded late and middle Pleistocene sediments from the cliffs, and demonstrate that little Holocene sediment from the shelf or shore has been transported to the upper ridge surface. Further, they highlight the importance of an independent assessment of ${ }^{14} \mathrm{C}$ ages on carbonate.

\subsubsection{Woomerangee Hill Section ( $S W G 1 / 2)$}

The sedimentology of the upper SWG dune ("D") units is similar to SMT. Field surveys in the area indicate accretionary eolian bedforms up to $+200 \mathrm{~m}$. The coarse grain size and preservation of biogenic grain textures suggest the dunes had a nearby source within a few kilometres. Even the uppermost limestone and paleosol units are highly indurated (Figs. 10 and 11), however, and break only with strong hammer blows. Many of the lower units are well indurated with nearly complete intergranular cementation and recrystallization. The exposed ridge surface near Woomerangee is a deeply (1-2m) pitted, irregular karst surface (Fig. 10B). The diagenetic grade $\mathrm{V}$ throughout SWG is somewhat greater than the top of SMT, while a line of caves (Fig. 10A) at the boundary between couplets $\mathrm{D} / \mathrm{S} 7$ and $\mathrm{D} / \mathrm{S} 8$ accentuates the advanced stages of limestone weathering.

\subsubsection{Amino acid results at Woomerangee Hill (SWG1/2)}

WR AAE analyses of several units in the upper twothirds of the section reveal samples with decreasing $A / I$ values in stratigraphically lower units (Fig. 11): 0.48/0.22 in D9, 0.42 in D8, 0.08 in D4, and 0.11 in D3. The oldest units yield subsamples with low or non-detectable levels of 
Section $3 \mathrm{~km}$ north of Woomerangee Hill

(S.Lat: $26.884^{\circ}$; E. Long. $113.749^{\circ}$ )

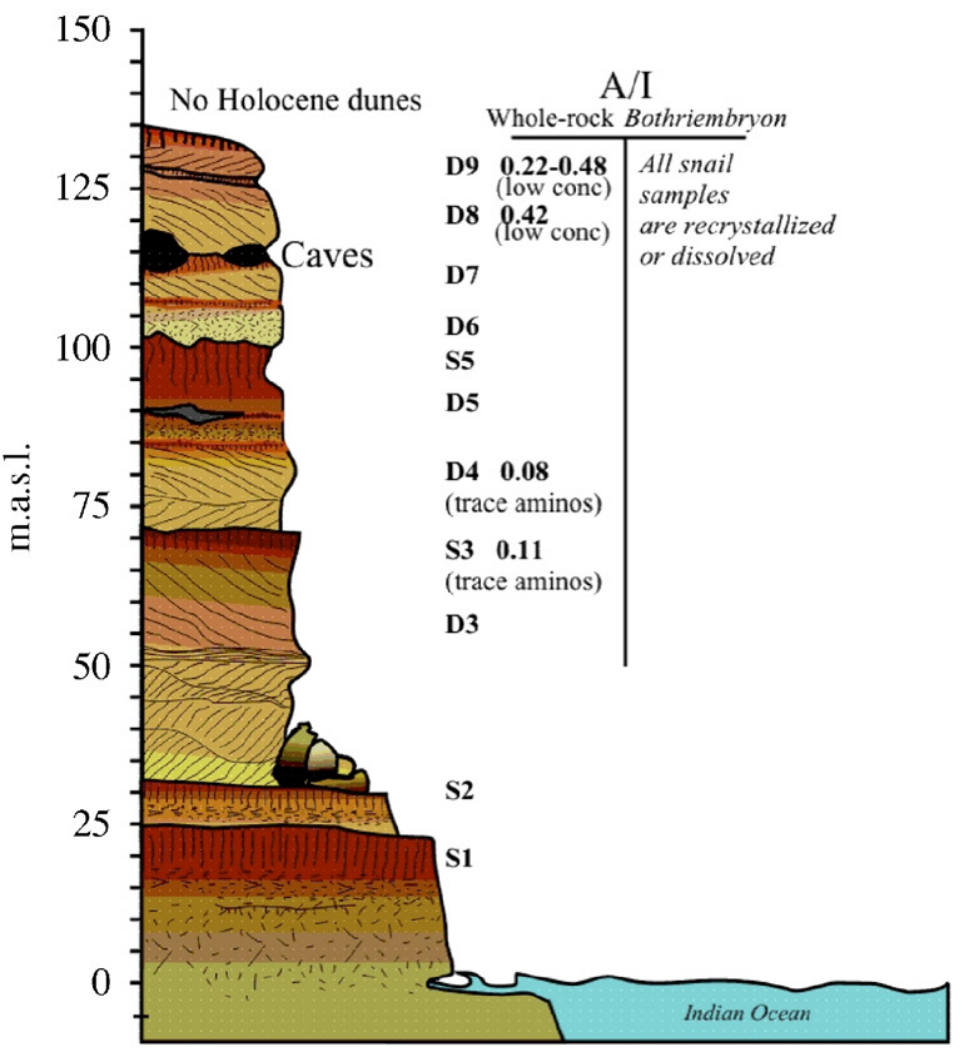

\section{Zuytdorp Cliffs sections}

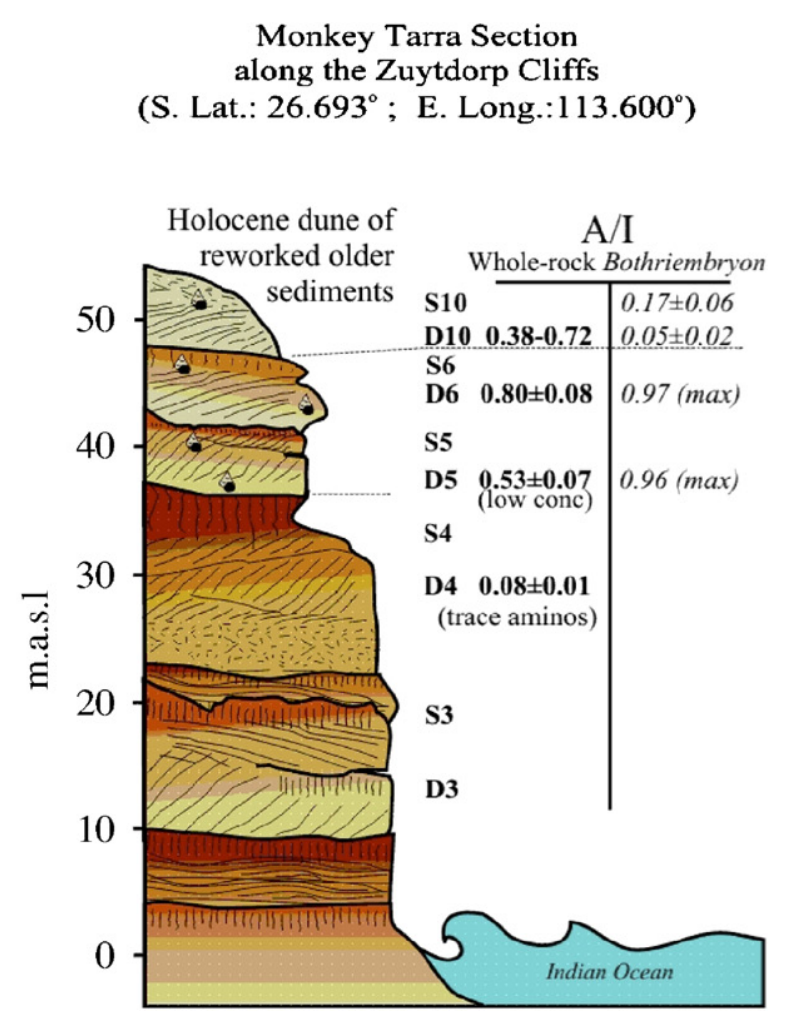

Fig. 11. Stratigraphic logs and mean $A / I$ values from Woomerangee Hill and Monkey Tarra, Zuytdorp Cliffs. The stratigraphic complexity, advanced stage of diagenesis, non-detectable levels of amino acids, and comparisons with other Quaternary sequences suggest the mid-to-upper Zuytdorp Cliffs at Woomerangee are at least $>500 \mathrm{ka}$, and possibly well over $1 \mathrm{Ma}$. Darker colors represent reddened paleosol horizons while the lighter colors are bioclastic eolianite (see Fig. 10).

amino acids $(0-35 \mathrm{nM} / \mathrm{mg})$. This decrease in $A / I$ parallels that of SMT. In contrast, WR deposits within Shark Bay, only $13 \mathrm{~km}$ east of SMT, and $30 \mathrm{~km}$ north of SWG, yield higher concentrations, up to about $100 \mathrm{nM} / \mathrm{mg} A+I$, and apparently reliable $A / I$ values up to 0.97 (SBA3).

All Bothriembryon in SWG stratigraphic units were entirely recrystallized and more often dissolved in situ, yielding shell impressions. As a result, no Bothriembryon were analyzed from the SWG section. The presumed extinct $B$. ride $i$ (Kendrick, 1978 and personal communication), from Edel Land north of Zuytdorp Cliffs produce $A / I$ values as high as 1.11 (Table A1; Fig. 6), indicating a minimum APK age of $>300-400 \mathrm{ka}$. B. costulatus (Lamarck) from the base of Eagle Lookout in Shark Bay produced a near-equilibrium $A / I$ value of 1.22, indicating an age of well over $400 \mathrm{ka}$. Eolianite and marine carbonates $>780 \mathrm{ka}$ exhibit some of the most extensive cave development in WA along the LeeuwinNaturalist ridge in the Augusta karst area (Eberhard, 2004). Internal molds are the most common evidence of land snails in these rocks, however, several B. naturalistarum shells from these deposits yield exclusively non-detectable levels of amino acids (unpublished data) from recrystallized shells. Lacking alternative explanations, these results from WR and land snails suggest that the uppermost units at SWG and mid-to-lower units at SMT are most likely older than the oldest deposits within Shark Bay and on neighboring Edel Land; that is, much older than $500 \mathrm{ka}$. Morphostratigraphic evidence further suggests that the development of the basin at Shark Bay could not progress without closure of its western margin by the earlier build up of the Zuytdorp ridge.

\section{Discussion}

\subsection{A regional view of age sequences of eolianites in $W A$}

Across the three regions representing much of coastal WA, the most commonly occurring eolianites range between MIS $1(<6-7 \mathrm{ka})$ and MIS 11-13 (<500 ka) based on AAE-APK age estimates (Fig. 6). Holocene beaches and dunes are ubiquitous along the coast, yet spatially separated by headlands, often of last interglacial age or older bedrock. Several late Pleistocene (Aminozone E) coral reefs exposed at Foul Bay (near Hamelin Bay), Rottnest Island, Leander Point, Dongara, Shark Bay (Tetradon), Cape Cuvier, and throughout Cape Range have been dated by U/Th (cited papers and Table 4), and provide independent APK age calibration for Aminozone E across a steep climate gradient. Middle Pleistocene ridges lie a few kilometers inland, where they are increasingly 
buried by younger deposits. Early Pleistocene outcrops are rare along the coastline of WA. Where present, they generally display massive accumulations and extensive cave development.

\subsection{Representative Quaternary limestone-eolianite sequences in $W A$}

Rottnest-Perth - A complex of late Pleistocene (Aminozone $\mathrm{E}$ and $\mathrm{C}$ ) and Holocene (Aminozone A) eolianite and marine deposits are dominant on Rottnest Island (Hearty, 2003; Hearty et al., 2007) (Fig. 4A). On the mainland along the Swan River estuary in Perth, late and middle Pleistocene rocks (Murray-Wallace and Kimber, 1989; Hearty, 2003) are exposed in several cliff sections (Minim Cove (Aminozone E); Peppermint Grove (Aminozone F?/G), Mt. Eliza at King's Park (> Aminozone H)) and in road cuttings and quarries south and north of Perth.

Cape Naturaliste to Cape Leeuwin-Important components of the Quaternary coastal stratigraphy are exposed between Cape Leeuwin and Cape Naturaliste. At Conto's Beach (Fig. 4B) south of Cape Freycinet to near C. Leeuwin, a well-developed Holocene sequence directly abuts an early Pleistocene coastal ridge, which contains the most extensive Quaternary cave system in WA (Eberhard, 2004). This site demonstrates how antecedent topography may create large gaps in the rock record. Late Pleistocene marine and eolian sediment is exposed at numerous sites including Cowaramup, Hamelin Bay (Fig. 4C), and Quarry Bay, the latter of which also contains outcrops of middle Pleistocene eolianite (Fig. 4D).

Guilderton and Nambung Pinnacles-The "Pinnacles" are striking pillar-like rock formations that occur $4-6 \mathrm{~km}$ inland of the WA coastline at several localities between Perth and Cervantes, and are the central natural attraction of Nambung National Park. These stone columns emerge several meters from the desert floor and are generally $1-3 \mathrm{~m}$ in diameter. At Nambung NP, the pinnacles, often partially buried by pure quartz sand (Fig. 4E), are composed of a variety of sediment types and internal structures including carbonate sand, quartz sand, thick (often $>50 \mathrm{~cm}$ ) and highly indurated micritic calcrete, red clayey soil, and rhizomorphs. Despite their spectacular and widespread occurrence in the area, little scientific research has been dedicated to understanding how and when they formed (see McNamara, 2002).

At Guilderton Quarry (Fig. 4F), pinnacles are progressively exhumed from within an eolianite sand quarry. The eolianite yields WR $A / I$ values of 0.52 , correlated with Aminozone $\mathrm{H}$, estimated to be ca. $400 \mathrm{ka}$ old. Considerably younger Aminozone $\mathrm{E}$ deposits $(A / I=0.32)$ are located $5 \mathrm{~km}$ westward at the coastline at Guilderton. The complexity and advanced stages of diagenesis of the pinnacles, manifest by massive calcretes and complex internal structure, combined with their inland morphostratigraphic position, are commensurate with an APK age estimate of ca. $400 \mathrm{ka}$. This age estimate contrasts with the youthful age of formation of $25 \mathrm{ka}$ suggested by McNamara (2002).
We interpret the pinnacles as the preserved casts and molds of large trees in ancient forests, buried by the advance and aggradation of coastal eolianites. The casts create conduits for groundwater and precipitation of calcrete, which ultimately fill and become more highly indurated than the enclosing eolianite. When the eolianite is eroded, the more-resistant pillars are left standing in relief (Fig. 4EF). The process of tree burial and casting during have been described for last-interglacial eolianites in Bermuda and the Bahamas (Neumann and Hearty, 1996; Hearty and Kindler, 1997), and provides a model to explain pinnacle formation in south-central WA.

\subsection{Global comparisons of the parallel diagenetic effects on amino acids and aging limestone}

These geochemical and chronostratigraphic findings from both WR and land-snails are in general agreement with late Quaternary successions from Bermuda (Hearty et al., 1992), Bahamas (Hearty and Kaufman, 2000), and Hawaii (Hearty et al., 2000, 2005a, b), as well as with the apparent relative ice-volume/sea-level changes interpreted from deep-sea $\delta^{18} \mathrm{O}$ records (Fig. 12; from Raymo et al., 1990). These studies support a trend of greater highstand amplitude over the past $0.5 \mathrm{Ma}$ (MIS 13 to 1 ; identified as Interval "iv" in Fig. 12, with the probable exception of MIS 7) particularly during MIS 11, 9, and 5e. During Interval "iii" (0.5-1.0 Ma; Fig. 12), peak interglacial sea levels were comparatively lower than Interval "iv". During this interval of lower highstands, carbonate sediment was either sparsely or not deposited across large areas of the coastal zone currently above sea level. Lacking carbonate input, this interval was characterized by the development of dense, red and clayey soils (aka "Big Red Soil" or BRS of Hearty et al., 2005a) on coastal limestone. Although we have yet to confirm BRS correlatives in WA, sections at Cape Peron, Broadhurst North, and Monkey Mia expose dense, deep red clayey paleosols of middle Pleistocene or older age in basal units, similar to the BRS.

Quaternary limestone successions and mean aminozone $A / I$ values in Bermuda, Bahamas, and Hawaiian are comparable to SW and NW WA (Tables 5 and 7). Bermuda shares not only similar latitudes as Perth and Rottnest $\left(\sim 32^{\circ} \mathrm{N}\right)$, but also similar average climate and mean annual temperature (MAT) (ca. $18-20^{\circ} \mathrm{C}$ ) compared to SW WA. Mean WR aminozone values are nearly identical between these distant localities (Hearty, 2003; Table 7). Likewise, mean temperatures of ca. $24-25^{\circ} \mathrm{C}$ and latitudes of $21-24^{\circ} \mathrm{N}$ latitude from the Bahamas and Hawaiian Islands (Kauai, Oahu, and Molokai) are similar to those in NW WA.

In these cases, AAE results from carbonate sequences show consistent reliable mean $A / I$ 's in stratigraphic units assigned to Aminozone $\mathrm{H}$. Rocks older than the BRS generally show a reversal in $A / I$ or non-detectable levels of amino acids (Table 7). We suspect these factors are closely linked to recrystallization and karst processes, which are almost always more advanced in early Pleistocene rocks 


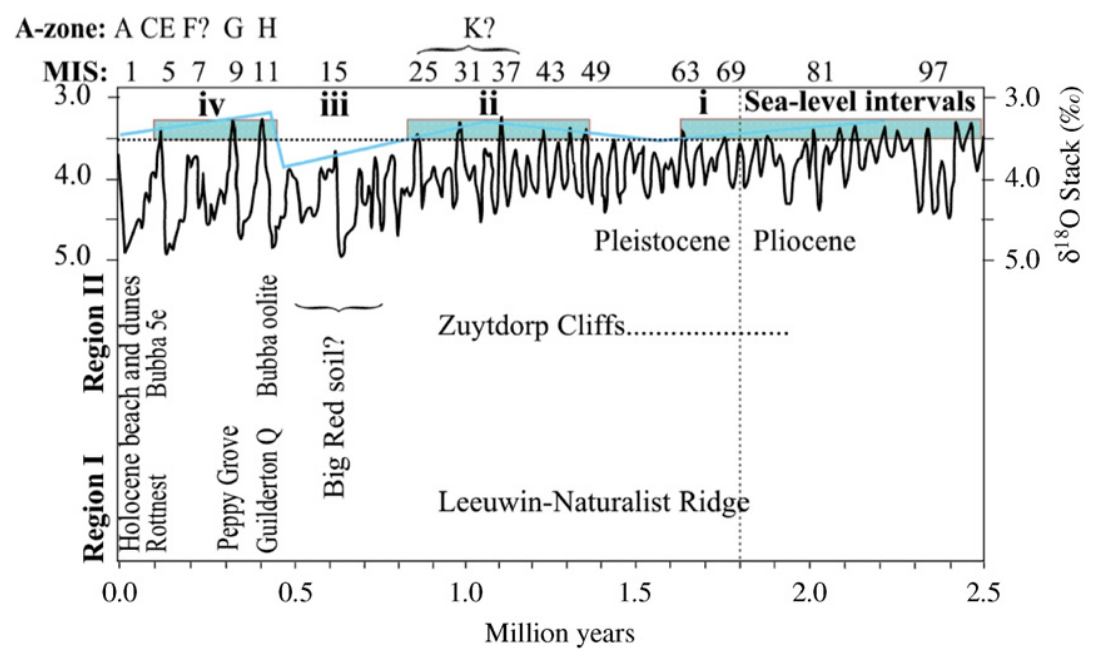

Fig. 12. Deep-sea isotope curve from Raymo et al. (1990) from which generalized ice-volume changes are interpreted. Several intervals ("i"-"iv") of higher and lower relative high stands are recognized between the late Pliocene and the present. The majority of eolianite exposures and aminozones on the Western Australia coastal plain are correlated with the latest interval "iv", while those from the type Tamala Limestone at the Zuytdorp Cliffs are correlated with interval "ii".

predating the Brunhes at $>0.78 \mathrm{Ma}$ in these regions (Hearty et al., 1992, 1996). Thus, by comparison, geologic and AAE data from Bermuda, Bahamas, and Hawaii further support an early Pleistocene age of the Zuytdorp Cliffs, as suggested over three decades ago by Logan et al. (1970, 1974). MIS 25, 31, and 37 stand out as important interglacials (Fig. 12) during which many of these older units may have been deposited. We anticipate future $\mathrm{Sr}$ isotopic and paleomagnetic studies will corroborate these observations.

\subsection{Highstand or lowstand eolianites?}

This investigation has proceeded under the well-supported premise that eolianites represent supratidal shoreline facies deposited during peak interglacial highstands. A "peak highstand" includes three intervals: (1) the approach of sea level to its maximum position during transgression, (2) the interval when sea level stabilizes at or has minor shifts within its general maximum still stand position, and (3) the fall of sea level from its maximum position at the onset of glaciations. The configuration of the shelf and nearshore ramp, supply of sediments, onshore energy vectors, and magnitude of superimposed fluctuations on the highstand curve must also be considered along each coastline. Each interglacial has a maximum sea-level position above, at, or lower than present, during which eolian sediments can be delivered to each of these zones. Eolianites discovered by drilling far below present sea level may have been deposited during significantly lower, or much older peak sea levels, or as sediment was shifted down slope.

Our stratigraphic, sedimentological, and AAE findings support the basic assumption of predominantly highstand deposition of eolianites with the following arguments:

Uniformitarianism - Eolianites are being deposited during the current Holocene highstand in WA. Subtidal, intertidal, and supratidal facies can be observed in shallowing-upward sequences formed during the current highstand. AAE independently demonstrates the age equivalence of subtidal, intertidal, and supratidal facies for Holocene and older interglacial deposits. U/Th-dated and AAE-correlated last-interglacial marine and eolian facies are rich in carbonate $(>80 \%$ in most cases) and confirm a correlation with highstand events.

Diagenesis - Carbonate sediments, rich in aragonite, indurate rapidly under vadose conditions, and thus are not prone to migration. Once emplaced above sea level, the dunes are rapidly colonized by plants and animals, and quickly cement at grain contacts in the vadose environment.

Temporal limitations-At Eagle Bluff, Shark Bay, for example, there are a minimum of twelve terrigenous quartz dunes and soil units, but only two or three intercalated lenses of carbonate representing the stratigraphic record for the past ca. $400 \mathrm{ka}$ (Donald, 2003). Considering that glacial periods comprise the majority $(\sim 90 \%)$ of the Quaternary Period, if carbonate dunes were constantly migrating across the continental shelf by "winds... considerably stronger during the glacial periods" (Playford, 1997, p. 794), deposition of a greater amount of carbonate sediment would be expected in the deposits.

Sedimentology-The coarse grain size in most eolianites suggests proximity to a high-energy shoreline. After tens of kilometres of migration, progressively finer-grained and smaller volumes of sands and silts would remain, inhibiting further dune propagation.

Geographic and topographic barriers-The distance from the lowstand shoreline to the present coastal ridges of WA ranges is between 50 and $100 \mathrm{~km}$. Carbonate dunes generally do not migrate more than a few kilometers unless repeatedly disturbed by fire or overgrazing (Hearty et al., 2000). If this occurred, sediments would be transported as transverse or more likely parabolic dunes or barchanoid dunes. These dunes would probably not maintain a constant volume, but rather would be 
Table 7

Proposed correlation of marine isotope stages (MIS), and aminozones of major units in WA Regions I and II with whole-rock aminostratigraphic successions from Bermuda, Bahamas, and the Hawaiian Islands

\begin{tabular}{|c|c|c|c|c|c|c|}
\hline $\begin{array}{l}\text { Amino- } \\
\text { zone }\end{array}$ & $\begin{array}{l}\text { WA Region I } \\
\text { (this study) } \\
\text { and Hearty (2003) } \\
\text { in bold }\end{array}$ & $\begin{array}{l}\text { WA Region II } \\
\text { Shark Bay and } \\
\text { Zuytdorp Cliffs } \\
\text { (this study: bold) }\end{array}$ & $\begin{array}{l}\text { Bermuda }^{a} \\
\text { site } / F m\end{array}$ & $\begin{array}{l}\text { Bahamas }^{\mathrm{b}} \\
\text { New } \\
\text { Providence, } \\
\text { Eleuthera, and } \\
\text { Exuma Islands }\end{array}$ & $\begin{array}{l}\text { Hawaiian Islands } \\
\text { Oahu, Kauai } \\
\text { (couplets), and } \\
\text { Molokai Islands }\end{array}$ & MIS \\
\hline A 3 & $\begin{array}{l}\text { Modern } \\
\text { beach-dunes }\end{array}$ & $\begin{array}{l}\text { Modern } \\
\text { beach-dunes }\end{array}$ & $\begin{array}{l}\text { Modern } \\
\text { beach } \\
0.12 \pm 0.01(2)\end{array}$ & $\begin{array}{l}\text { Modern beach- } \\
\text { dunes } 0.05 \pm 0.02(3)\end{array}$ & $\begin{array}{l}\text { Modern } \\
\text { beach-dunes } \\
0.11 \pm 0.03(7) \\
\text { Couplet VIII }\end{array}$ & $\begin{array}{l}\text { Mod; } \\
\text { Late } 1\end{array}$ \\
\hline A1-2 & Unit VI & $\begin{array}{l}\text { Unit m; } \\
\text { eolianite }\end{array}$ & & $\begin{array}{l}\text { Windermeer I } \\
0.10 \pm 0.01(2)\end{array}$ & & $\begin{array}{l}\text { Mid/ } \\
\text { late } 1\end{array}$ \\
\hline $\mathrm{C} / \mathrm{D}$ & $\begin{array}{l}\text { Rottnest upper } \\
\text { eolianites } \\
\text { Unit V }\end{array}$ & $\begin{array}{l}\text { Unit k; } \\
\text { eolianite }\end{array}$ & $\begin{array}{l}\text { Southampton } \\
\text { Fm } \\
0.23 \pm 0.03(3)\end{array}$ & $\begin{array}{l}\text { Green Cay; First } \\
\text { Bay } \\
0.29 \pm 0.03(5)\end{array}$ & $\begin{array}{l}0.34 \pm 0.01(6) \\
\text { Couplet VIIb }\end{array}$ & $5 \mathrm{a} / 5 \mathrm{c} ?$ \\
\hline E2 & $\begin{array}{l}\text { Minim Cove } \\
\text { Unit IV }\end{array}$ & $\begin{array}{l}\text { Unit h; } \\
\text { Eagle Bluff; } \\
\text { Baba Head } \\
\text { Bibra Fm }\end{array}$ & $\begin{array}{l}\text { Rocky Bay Fm } \\
0.27 \pm 0.03(13)\end{array}$ & $\begin{array}{l}\text { Lyford Cay; } \\
\text { Boiling Hole } \\
0.38 \pm 0.02(12)\end{array}$ & $\begin{array}{l}0.46 \pm 0.04(27) \\
\text { Couplet VIIa }\end{array}$ & $\begin{array}{l}\text { Late } \\
5 \mathrm{e}\end{array}$ \\
\hline E1 & $\begin{array}{l}\text { Fairbridge reef } \\
\text { Unit IV }\end{array}$ & $\begin{array}{l}\text { Gladstone } \\
\text { North }\end{array}$ & $\begin{array}{l}\text { Grape Bay Mb } \\
0.40 \pm 0.02(13)\end{array}$ & & $\begin{array}{l}0.51 \pm 0.03(11) \\
\text { Couplet VIIa }\end{array}$ & $\begin{array}{l}\text { Early } \\
5 \mathrm{e}\end{array}$ \\
\hline $\mathrm{F} ? / \mathrm{G}$ & $\begin{array}{l}\text { Peppermint } \\
\text { Grove } \\
\text { Unit III }\end{array}$ & Dampier Fm & $\begin{array}{l}\text { Upper Town } \\
\text { Hill Fm } \\
0.49 \pm 0.04(11)\end{array}$ & $\begin{array}{l}\text { Blue Hill; } \\
\text { Glass Window } \\
0.58 \pm 0.01(3)\end{array}$ & $\begin{array}{l}0.65 \pm 0.01(2) \\
\text { Couplet VI/V }\end{array}$ & $7 ? / 9$ \\
\hline $\mathrm{H}$ & $\begin{array}{l}\text { Guilderton } \\
\text { and Nambung } \\
\text { Pinnacles } \\
\text { Unit II }\end{array}$ & $\begin{array}{l}\text { Unit a; } \\
\text { Baba Head } \\
\text { yellow oolite }\end{array}$ & $\begin{array}{l}\text { Lower Town } \\
\text { Hill Fm } \\
0.67 \pm 0.03(6) \\
405 \pm 5 \mathrm{ka}\end{array}$ & $\begin{array}{l}\text { Hunt's Q; } \\
\text { Goulding Cay } \\
0.67 \pm 0.05(16) \\
<550 \mathrm{ka}\end{array}$ & $\begin{array}{l}0.81 \pm 0.08(6) \\
\text { Couplet IV }\end{array}$ & 11 \\
\hline $\begin{array}{l}\text { Big } \\
\text { red } \\
\text { soil }\end{array}$ & $\begin{array}{l}\text { No known } \\
\text { equivalent }\end{array}$ & $\begin{array}{l}\text { BRS? } \\
\text { Basal units } \\
\text { Peron Pen }\end{array}$ & $\begin{array}{l}\text { Government/ } \\
\text { Wilkinson } \\
\text { Quarries }\end{array}$ & $\begin{array}{l}\text { Exuma cores: } \\
\text { BRS }^{\mathrm{d}}\end{array}$ & $\begin{array}{l}\text { Wiopili Quarry, } \\
\text { Kauai, BRS }\end{array}$ & $\begin{array}{l}12- \\
24 ?\end{array}$ \\
\hline $\mathrm{K}$ & $\begin{array}{l}\text { Leeuwin- } \\
\text { Naturaliste } \\
\text { ridge }^{\text {e }} \text { (e.g., } \\
\text { Jewel Caves); } \\
\text { all ND }\end{array}$ & $\begin{array}{l}\text { Zuytdorp } \\
\text { Cliffs units; } \\
\text { low } A / I \text { and } \\
\text { ND }\end{array}$ & $\begin{array}{l}\text { Walsingham } \\
\text { Fm Reverse } \\
\text { Polarity } \\
1.11 \pm 0.02(3) \\
\text { mostly ND }\end{array}$ & $\begin{array}{l}\text { Exuma Cays }^{\mathrm{d}} \\
\text { Reverse polarity; } \\
\text { all ND }\end{array}$ & $\begin{array}{l}\text { All ND in } \\
\text { Couplets III, II, } \\
\text { and I }\end{array}$ & $\begin{array}{l}25 ? \\
\text { to } \\
37 ?\end{array}$ \\
\hline
\end{tabular}

Note: All correlations are based on aminostratigraphy and morphostratigraphic succession. Mean $A / I$ values of whole-rock samples from WA localities are listed in Table 5.

References:

${ }^{\text {a } H e a r t y ~ e t ~ a l . ~(1992) ; ~ H e a r t y ~ a n d ~ V a c h e r ~(1994) ; ~ H e a r t y ~ e t ~ a l . ~(1999) ; ~ H e a r t y ~(2002 a) . ~}$

${ }^{\mathrm{b}}$ Hearty and Kaufman (2000).

${ }^{\mathrm{c}}$ Hearty et al. (2000, 2005a, b).

${ }^{\mathrm{d}}$ Hearty et al. (1996; unpublished).

e Eberhard (2004).

thinned and distributed over large areas. The finite sediment supply (disconnected from source) and high rates of sediment dispersal would greatly inhibit long-distance migration in any dune form. Moreover, after migration of $50-100 \mathrm{~km}$ from the shelf break, it is unlikely that the dunes would cease to migrate, and "rack up" to form a succession of shore-parallel or stacked ridges as exists along the present coastline.

The Zuytdorp Cliffs themselves present a barrier to sand migration. If the current highstand of the Holocene cannot effectively deposit modern sediment on top of the Zuytdorp Cliffs $50-100 \mathrm{~m}$ high, as indicated by our samples, then a coastline $120 \mathrm{~m}$ lower, and $75 \mathrm{~km}$ distant from the present cliff would make transport and deposition of migrating dune sediment implausible.

Difficulties with preservation of lowstand dunesSubmerged shorelines and localized deposits, interpreted to be coastal dunes, have been described in proximity to glacial shorelines (James et al., 2004), but few such cases have been documented on mid-to-upper continental shelf areas of WA. If the sediment were unconsolidated, the carbonate dune morphology would effectively be destroyed by transgressing seas. If the lowstand dunes were indurated, vast fields of eolianites should be preserved across the continental shelf, which have not been detected. 


\subsection{Stratigraphic and AAE constraints on the ages of interbedded quartz deposits}

Pits, lenses, and beds of fine-to-coarse quartz sand occur across coastal SW WA. In Region I, the differences are accentuated with nearly pure quartz deposited on nearly pure carbonate beds. Farther north in Regions II and III, quartz is more common in eolianites, due to aridity and the proximity of continental dunes. The ages of many of the quartz deposits are constrained by their association with the AAE relative ages of bounding carbonates.

Our study does not support the "residual soil" formation theory (e.g., Bastian, 1996) as applicable to coastal WA for the following reasons:

(1) Primary dune morphology is preserved in most Aminozone $\mathrm{A}-\mathrm{H}$ carbonate-rich deposits of WA capped by quartz. Primary morphology would be lost if tens of meters of eolianite were dissolved.

(2) Eolianites retain their original pristine mineralogy (high percentage of aragonite) even where overlain by beds or localized pits of pure quartz. If quartz were being concentrated by dissolution of eolianites to become "residual soils" (Bastian, 1996), a pattern of increasing $\%$ quartz or decreasing $\%$ carbonate with age is expected. Instead, quartz beds are deposited on eolianites representing each of the aminozone deposits " $\mathrm{C}$ " through " $\mathrm{H}$ ". In a majority of cases $(55 \%)$, the insoluble quartz fraction is $100 \%$ (Table 2), while underlying eolianites are often of similar richness in $\mathrm{CaCO}_{3}$ (i.e., 80-99\%; Table A1). Thus, if the underlying carbonates are pristine, the overlying pure quartz beds are unlikely to be genetically related to them. Furthermore, the 30-40-m-high, pure-quartz dunes observed today among the coastal carbonates (for example, at Mandurah Quarry (Fig. 3D), Ankatel, and Lancelin: WMQ1, WAN1, and WLN1a in Table 2) cannot be explained by eolianite dissolution!

(3) Extensive diagenesis would be a precursor of dissolution, yet even after hundreds of thousands of years, there is no evidence of a dissolution front, increasing percentages of quartz in older deposits, or the progressive loss of carbonate in eolianite. Aminozones $\mathrm{A}-\mathrm{H}$ contain no significant karst or cave development that would be expected if these deposits were extensively dissolved over to yield pure and widespread quartz beds.

The essential physical evidence to support residual soil formation is lacking from WA. The quartz deposits in WA are more likely explained by continental dunes that expanded onto the coastal plain, as postulated by Semeniuk and Glassford (1988). The purity of the interbedded quartz and carbonate deposits (Allayialis, 2003) implies out-of-phase deposition of each mineral facies, presumably during glacial lowstand and interglacial phases, respectively.

\subsection{Is the Tamala-type locality representative of $W A$ eolianites?}

The preponderance of coastal eolianites sampled in WA is relatively young and datable by AAE, falling into Aminozones A through $\mathrm{H}$ at $\leqslant 500 \mathrm{ka}$ (Fig. 6). Most coastal-cliff profiles contain active modern, subactive, or stabilized Holocene dunes. A significant number of exposures are associated with the broad last interglacial (MIS 5) highstand, elsewhere dated between 80 and $130 \mathrm{ka}$. This interval comprises two groups, Aminozones $\mathrm{C}$ and $\mathrm{E}$, best exposed on Rottnest Island (Hearty, 2003). Along the Swan River estuary in Perth, facies exposures of older Aminozones $\mathrm{F}$ ?/G and $\mathrm{H}$ deposits are relatively complete.

The considerable length of time required for the development of up to 10 couplets of limestone with well-developed exposure surfaces and paleosols, together with the advanced state of diagenesis, including karst and cavernous weathering, indicate the type Tamala Limestone at the Zuytdorp Cliffs is of much greater age than most Quaternary eolianite exposed in the coastal zone between Cape Leeuwin and Cape Range. The quantified decrease in the concentration of amino acids from stratigraphically lower beds at the Zuytdorp Cliffs similarly reflects an age significantly greater than Aminozone H (ca. $400 \mathrm{ka}$ ) from nearby Shark Bay. In Bermuda, Bahamas, and Hawaii, amino acid concentrations decrease to unmeasurable levels in many dated deposits older than Aminozone $\mathrm{H}$ (Table 7) and the BRS. We therefore conclude that the middle and upper beds at the type locality at the Zuytdorp Cliffs are of early Pleistocene age, and those lower in the section perhaps may be as old as late Pliocene. To avoid the confusion associated with the type Tamala Limestone at the Zuytdorp Cliffs, we suggest restricting the term "Tamala Limestone" to the rocks at the Zuytdorp Cliffs, and propose new informal formational names, members, and type localities for Quaternary limestone eolianites that can be applied more broadly to marine deposits of WA (Table 8), and are guided by age and AAE correlations in Tables 5, 7, and Table A1.

\section{Conclusions}

A regional AAE survey of 200 sites in WA from the Southern Ocean to the Timor Sea reveals a dominance of Holocene and last interglacial (sensu lato) sites near the coastline, with fewer middle Pleistocene exposures further inland. The degree of carbonate diagenesis in older ridges generally increases landward but reveals only moderate recrystallization and induration, and minimal cavernous weathering in most deposits defined from WR and land snails as Aminozones A to $\mathrm{H}$. These aminozones most likely correlate with interglacials of MIS 1-11 or 13, based on APK age modelling and comparison with better-studied and dated Quaternary successions in Bermuda, Bahamas, and Hawaii.

Pure quartz sand deposits are often interbedded with the carbonates. These are not "residual soils" (the product of eolianite dissolution, leading to concentration of quartz). 
Table 8

Proposed informal nomenclature and type localities of coastal carbonates of SW (Region I) and central Western Australia (Region II)

\begin{tabular}{|c|c|c|c|c|c|c|}
\hline Division & $\begin{array}{l}\text { Informal name } \\
\text { and type locality }\end{array}$ & Subdivisions (members) & $\begin{array}{l}\text { Description (facies; diagenetic } \\
\text { grade; other features) }\end{array}$ & $\begin{array}{l}\text { Other named } \\
\text { correlatives South to } \\
\text { North }\end{array}$ & $\begin{array}{l}\text { Est age } \\
\text { (ka) }\end{array}$ & MIS \\
\hline \multirow[t]{3}{*}{ Holocene } & $\begin{array}{l}\text { Army Jetty fm } \\
\text { (Rottnest } \\
\text { Island) }\end{array}$ & Modern beach-dunes & $\begin{array}{l}\rightarrow \text { Fossiliferous marine and } \\
\text { eolian; loose to lightly } \\
\text { consolidated sand along most } \\
\text { WA coastlines }\end{array}$ & $\begin{array}{l}\text { Herschell mb } \\
\text { (Playford 1990) }\end{array}$ & 0 & \\
\hline & & Weak soil & & & & \\
\hline & & $\begin{array}{l}\text { Porpoise Bay mb (beach } \\
\text { and dunes) }\end{array}$ & $\begin{array}{l}\rightarrow \text { Mid-Holocene transgression } \\
\text { to present sea level }\end{array}$ & & 10 & 1 \\
\hline \multicolumn{7}{|c|}{ Major Paleosol-quartz dune sand } \\
\hline \multirow[t]{3}{*}{ Late Pleistocene } & Rottnest fm & Fish Hook Bay mb & $\begin{array}{l}\rightarrow \text { Primarily eolian facies with } \\
3-5 \text { interbedded protosols with } \\
\text { land invertebrates; lightly to } \\
\text { firmly cemented, brown soils }\end{array}$ & $\begin{array}{l}\text { Minim Cove } \\
\text { (Murray-Wallace } \\
\text { and Kimber, 1989) }\end{array}$ & 75 & $5 a-5 c$ \\
\hline & & Paleosol & & & & \\
\hline & & Fairbridge Bluff mb & $\begin{array}{l}\rightarrow \text { Reef and subtidal marine and } \\
\text { eolian facies; red soil cap }\end{array}$ & $\begin{array}{l}\text { Rottnest fm } \\
\text { (Playford, 1990) }\end{array}$ & 130 & $5 e$ \\
\hline \multicolumn{7}{|c|}{ Major Paleosol_quartz dune sand } \\
\hline \multirow[t]{5}{*}{$\begin{array}{l}\text { Middle } \\
\text { Pleistocene }\end{array}$} & $\begin{array}{l}\text { Guilderton fm } \\
\text { (Quarry } 5 \mathrm{~km} \\
\text { east of coast) }\end{array}$ & Peppermint Grove mb & $\begin{array}{l}\rightarrow \text { Fossiliferous marine and } \\
\text { eolian; firmly cemented sand; } \\
\text { capping red soils and thick } \\
\text { calcrete }\end{array}$ & $\begin{array}{l}\text { Peppermint Grove } \\
\text { (Murray-Wallace } \\
\text { and Kimber, 1989) }\end{array}$ & 190 & $7 / 9$ \\
\hline & & $\begin{array}{l}\text { Paleosols and quartz } \\
\text { sand }\end{array}$ & & & & \\
\hline & & Nambung mb & $\begin{array}{l}\rightarrow \text { Eolian facies with dense and } \\
\text { complex calcrete pillars or } \\
\text { pinnacles; altered } \mathrm{CaCO}_{3} \\
\text { minerals. }\end{array}$ & $\begin{array}{l}\text { Dampier fm (Logan } \\
\text { et al., 1970; 1974) }\end{array}$ & & 11 \\
\hline & & $\begin{array}{l}\text { Paleosols and quartz } \\
\text { sand }\end{array}$ & & & & \\
\hline & & Mt. Eliza mb & $\begin{array}{l}\rightarrow \text { Eolian facies with altered } \\
\mathrm{CaCO}_{3} \text { minerals }\end{array}$ & & 500 & $13 / 15$ \\
\hline \multicolumn{7}{|c|}{ Major Paleosol-quartz dune sand } \\
\hline \multirow[t]{2}{*}{$\begin{array}{l}\text { Early } \\
\text { Pleistocene }\end{array}$} & $\begin{array}{l}\text { Zuytdorp fm } \\
\text { (former Tamala } \\
\text { Limestone) }\end{array}$ & $\begin{array}{l}\text { Woomerangee } \mathrm{mb} . \mathrm{Up} \\
\text { to } 10 \text { cycles of } \\
\text { eolianite-paleosol } \\
\text { couplets }\end{array}$ & $\begin{array}{l}\rightarrow \text { Dense, highly cemented } \\
\text { eolianites with highly altered/ } \\
\text { recrystallized } \mathrm{CaCO}_{3} \text { minerals; } \\
\text { interbedded with quartz-rich } \\
\text { paleosols; cavernous weathering } \\
\text { at some levels }\end{array}$ & & $800 ?$ & $>25$ \\
\hline & & & & & $1800 ?$ & \\
\hline
\end{tabular}

Note: Ages are inferred or estimated based upon radiometric or amino acid epimerization data.

Neither extensive karst nor cavernous weathering, concomitant with dissolution to account for the abundance of pure quartz, is observed in these beds. Rather, we suggest that quartz sand is widely distributed across the coastal plain by eolian activity during regressive sea-level events. A minor northward shift of $10^{\circ}$ of the Southern Ocean convergence during glacials could account for the reversal in prevailing wind from onshore (current and interglacial pattern) to offshore (glacial periods) across much of SW WA.

Advanced limestone diagenesis, including recrystallization and speleogenesis, such as occurs at the Zuytdorp Cliffs, corresponds with low amino acid concentrations, generally producing lowing or non-detectable levels of amino acids. Nearby sites in Shark Bay, experiencing comparable environmental conditions, yield consistently high $A / I$ values on WR samples and land snail specimens up to 300-600 ka. We quantify this progressive change and interpret local contrasts in $A / I$ and amino acid $(A+I)$ concentration as a function of the much greater age of the Zuytdorp Cliffs. The stratigraphic development of the sedimentary basin at Shark Bay was almost certainly aided by the earlier closure of its western margin facing the Indian Ocean.

The results of this regional investigation indicate the Tamala Limestone at the Zuytdorp Cliffs does not accurately represent "typical" exposed coastal deposits of WA, and therefore is undesirable as a type locality.

New informal names and type localities are proposed. Rottnest Island contains a near complete succession and a variety of shoreline facies of late Pleistocene to Holocene carbonates and soils (Hearty, 2003). The well-described, 
shallowing-upward sequence exposed near the boathouse at Peppermint Grove along the Swan River in Perth (Murray-Wallace and Kimber, 1989; Hearty, 2003) is correlated with a younger middle Pleistocene highstand. A premier exposure of eolianite and unique morphological features (including "pinnacles") at Guilderton, Nambung National Park, and several other localities were developed somewhat earlier in the middle Pleistocene (MIS 11?). We propose that the type locality at Zuytdorp Cliffs be used only in reference to the massive coastal accretions over several early Pleistocene and perhaps late Pliocene interglacial cycles at several localities in WA.

\section{Acknowledgments}

We are grateful to D. Allayialis, B. Kinna, and A. Donald for their assistance in this project and great individual efforts while working on their respective theses. The submitted manuscript was greatly improved and streamlined through the significant constructive efforts of two anonymous reviewers and D. Kaufman. We greatly appreciate high quality of AAE data produced by the Amino Acid Laboratory at the Northern Arizona University (D. Kaufman, Director). AAE samples were analyzed and concentration data reduced by J. Bright and C. Orem. AMS ${ }^{14} \mathrm{C}$ age determinations were funded through an Australian Institute of Nuclear Science and Engineering grant (AINSE \#03-056) to PJH. Support for O'Leary's Ph.D. Thesis, U/Th analyses, and a portion of the cost for AAE analyses was provided by an ARC Discovery Grant (DP0209059) to McCulloch, Hearty and Halliday. We appreciate the guidance of McCulloch and his supervision of coral dating at the MC-ICPMS facility at the Australia National University. We thank the Kanagawa Museum (administered by the Australian Academy of Sciences) for funding to $\mathrm{PJH}$ for logistics and analyses during 2002-2003.

\section{Appendix A}

See Table A1.

Table A1

Summary of amino acid data for all sites and stratigraphic levels from Western Australia ranked by site mean $A / I$ of each sample material from each region

\begin{tabular}{lllllll}
\hline Site name & $\begin{array}{l}\text { Field } \\
\text { number }\end{array}$ & $\mathrm{Ca} \mathrm{CO}_{3}$ & $\begin{array}{l}\text { Latitude } \\
\left({ }^{\circ} \mathrm{S}\right)\end{array}$ & $\begin{array}{l}\text { Longitude } \\
\left({ }^{\circ} \mathrm{E}\right)\end{array}$ & $\begin{array}{l}A / I(\text { site } \\
\text { mean })\end{array}$ & $\begin{array}{l}\text { AAE age, }{ }^{14} \mathrm{C} \\
\text { or U/Th } \\
\text { calibration }\end{array}$ \\
\hline
\end{tabular}

\begin{tabular}{|c|c|c|c|c|c|c|c|c|}
\hline \multicolumn{9}{|l|}{ Region I WR } \\
\hline \multicolumn{9}{|l|}{ Aminozone $A$} \\
\hline $\begin{array}{l}\text { Cervantes } \\
\text { beach }\end{array}$ & WCV1z & 99 & No GPS & No GPS & 0.069 & 0.005 & 2 & A \\
\hline Cerv. Pinnacles & WCP1x & 74 & No GPS & No GPS & 0.168 & 0.003 & 2 & Al \\
\hline Greenhead & WGH2x & & 30.072 & 114.9619 & 0.185 & 0.000 & 2 & Al \\
\hline Quarry Bay & QBY1a & 83 & 34.367 & 115.1357 & 0.192 & 0.002 & 2 & $?$ \\
\hline Cerv. Pinnacles & WCP3x & 83 & No GPS & No GPS & 0.205 & 0.001 & 2 & Al \\
\hline Cowaramup & CMPla & 93 & 33.867 & 114.9795 & 0.209 & 0.007 & 2 & Al \\
\hline Cosy Corner & CCR3a & 95 & 34.263 & 115.0336 & 0.211 & 0.017 & 2 & Al \\
\hline Hamelin Bay & HBY le & 99 & 34.224 & 115.0239 & 0.218 & 0.004 & 2 & Al \\
\hline Hamelin Bay & WHB1c & 98 & 34.224 & 115.0239 & 0.221 & 0.016 & 2 & Al \\
\hline Leeman & WLE2x & & 29.926 & 114.9794 & 0.222 & 0.004 & 2 & Al \\
\hline \multicolumn{9}{|l|}{ Aminozone $C$} \\
\hline Mimim Cove & $\mathrm{PMC} 2 \mathrm{~b}(2)$ & 59 & 32.025 & 115.7673 & 0.226 & 0.074 & 2 & $?$ \\
\hline Hamelin Bay & WHB1d & 99 & 34.224 & 115.0239 & 0.227 & 0.003 & 2 & $\mathrm{C} 2$ \\
\hline Cowaramup & CMP2a & 77 & 33.866 & 114.9750 & 0.228 & 0.015 & 2 & $\mathrm{C} 2$ \\
\hline Hamelin Bay & HBY $2 x$ & 99 & 34.225 & 115.0238 & 0.231 & 0.004 & 2 & $\mathrm{C} 2$ \\
\hline Hamelin Bay & HBY1g & 99 & 34.224 & 115.0239 & 0.236 & 0.007 & 2 & $\mathrm{C} 2$ \\
\hline Waneroo & WWN1a & & 31.653 & 115.7339 & 0.237 & 0.045 & 2 & $?$ \\
\hline Hamelin Bay & WHB1f & 96 & 34.224 & 115.0239 & 0.239 & 0.004 & 2 & $\mathrm{C} 2$ \\
\hline Cosey Corner & CCR5d & 95 & 34.264 & 115.0341 & 0.241 & 0.018 & 2 & $\mathrm{C} 2$ \\
\hline Hamelin Bay & HBY2a & 99 & 34.225 & 115.0238 & 0.241 & 0.003 & 2 & $\mathrm{C} 2$ \\
\hline Cosy Corner & CCR3c1 & 73 & 34.263 & 115.0336 & 0.246 & 0.021 & 2 & $\mathrm{C} 2$ \\
\hline Coolimba & LCOlc & 94 & 29.812 & 114.9753 & 0.247 & 0.006 & 2 & $?$ \\
\hline Hamelin Bay & WHB1a & 98 & 34.224 & 115.0239 & 0.253 & 0.006 & 2 & $\mathrm{C} 1$ \\
\hline \multicolumn{9}{|l|}{ Aminozone $E$} \\
\hline Mimim Cove & PMCla & 97 & 32.024 & 115.7652 & 0.258 & 0.006 & 2 & $\mathrm{E}$ \\
\hline Peppy Grove & WPM1aa & 68 & No GPS & No GPS & 0.268 & 0.108 & 2 & $?$ \\
\hline Foul Bay & MFU1b & 98 & 34.249 & 115.0284 & 0.270 & 0.004 & 2 & $\mathrm{E}$ \\
\hline Toms thicket & PTT2a(3) & 88 & 32.654 & 115.6272 & 0.272 & 0.007 & 2 & $\mathrm{E}$ \\
\hline Guilderton & PGU5c & 91 & 31.353 & 115.4976 & 0.272 & 0.007 & 2 & $\mathrm{E}$ \\
\hline
\end{tabular}


Table Al (continued)

\begin{tabular}{|c|c|c|c|c|c|c|c|c|c|}
\hline Site name & $\begin{array}{l}\text { Field } \\
\text { number }\end{array}$ & $\mathrm{Ca} \mathrm{CO}_{3}$ & $\begin{array}{l}\text { Latitude } \\
\left({ }^{\circ} \mathrm{S}\right)\end{array}$ & $\begin{array}{l}\text { Longitude } \\
\left({ }^{\circ} \mathrm{E}\right)\end{array}$ & $\begin{array}{l}A / I \text { (site } \\
\text { mean) }\end{array}$ & \pm 1 & $N$ & Aminozone & $\begin{array}{l}\text { AAE age, }{ }^{14} \mathrm{C} \\
\text { or } \mathrm{U} / \mathrm{Th} \\
\text { calibration }\end{array}$ \\
\hline Cervantes & CCVla(1) & 99 & 30.526 & 115.0742 & 0.277 & 0.005 & 2 & $\mathrm{E}$ & \\
\hline Waneroo & WWN1c & & 31.653 & 115.7339 & 0.282 & 0.016 & 2 & E2 & \\
\hline Cowaramup & CMP1g & 96 & 33.867 & 114.9795 & 0.290 & 0.012 & 2 & $\mathrm{E}$ & U/Th; Table 4 \\
\hline Cosy Corner & CCR1c(2) & 77 & 34.261 & 115.0331 & 0.303 & 0.005 & 2 & $\mathrm{E}$ & \\
\hline Lancelin & WLN2b? & & 31.051 & 115.3804 & 0.310 & 0.032 & 2 & $\mathrm{E}$ & \\
\hline Mimim Cove & PMC2b(1) & 54 & 32.024 & 115.7652 & 0.316 & 0.021 & 2 & $\mathrm{E}$ & \\
\hline Cottesloe Beach & WCT1b & 52 & No GPS & No GPS & 0.322 & 0.041 & 2 & E2 & \\
\hline Guilderton & PGU5a & 66 & 31.353 & 115.4976 & 0.324 & 0.029 & 2 & $\mathrm{E}$ & \\
\hline Quarry Bay & QBY1c & 84 & 34.367 & 115.1357 & 0.325 & 0.019 & 2 & $\mathrm{E}$ & \\
\hline Leander Point & WLP1c & 44 & 29.278 & 114.9132 & 0.328 & 0.000 & 2 & $\mathrm{E}$ & U/Th; Table 4 \\
\hline Point Peron & PPP1 & 85 & 32.326 & 115.4133 & 0.329 & 0.009 & 2 & $\mathrm{E}$ & \\
\hline Mimim Cove & PMC2d & 71 & 32.024 & 115.7652 & 0.338 & 0.006 & 2 & $\mathrm{E}$ & \\
\hline Toms thicket & PTT2c & 83 & 32.654 & 115.6272 & 0.340 & 0.001 & 2 & $\mathrm{E}$ & \\
\hline Cowaramup & CMP1d & 93 & 33.867 & 114.9795 & 0.348 & 0.006 & 2 & $\mathrm{E}$ & \\
\hline Leeman & WLEla & & 29.925 & 114.9794 & 0.349 & 0.017 & 2 & $\mathrm{E}$ & \\
\hline Leander Point & WLP1c & & 29.278 & 114.9132 & 0.362 & 0.010 & 2 & $\mathrm{E}$ & U/Th; Table 4 \\
\hline Coolimba & 48.LCO1a & 99 & 29.812 & 114.9753 & 0.364 & 0.022 & 2 & E1 & \\
\hline Peppy Grove & WPM1b & 76 & No GPS & No GPS & 0.392 & 0.005 & 2 & $?$ & \\
\hline White Point & WWPla & & 29.475 & 115.0236 & 0.395 & 0.002 & 2 & E1 & \\
\hline Greenhead & WGH1a & & 30.072 & 114.9613 & 0.417 & 0.006 & 2 & $\mathrm{E}$ & \\
\hline White Point & WWP2a & & 29.549 & 115.0755 & 0.419 & 0.006 & 2 & $\mathrm{E} 1$ & \\
\hline \multicolumn{10}{|c|}{ Aminozone $F ? / G / H$} \\
\hline Jurien & WJR1a & & 30.349 & 115.0701 & 0.460 & 0.059 & 2 & $\mathrm{~F} / \mathrm{G}$ & \\
\hline Lancelin & WLN2a & & 31.051 & 115.3804 & 0.473 & 0.008 & 2 & $\mathrm{~F} / \mathrm{G}$ & \\
\hline Fremantle fort & FRA1 & 86 & No GPS & No GPS & 0.478 & 0.000 & 2 & $>\mathrm{F} ? / \mathrm{G}$ & \\
\hline Cliff head & DCH1a & 66 & 29.516 & 114.9966 & 0.491 & 0.069 & 2 & $\mathrm{~F} / \mathrm{G}$ & \\
\hline Jurien & WJR2a & & 30.442 & 115.0854 & 0.499 & 0.000 & 2 & $\mathrm{~F} / \mathrm{G}$ & \\
\hline Guilderton & PGUla & 83 & 31.33 & 115.5103 & 0.523 & 0.024 & 2 & $\mathrm{H}$ & $>350 \pm 50 \mathrm{ka}$ \\
\hline QB Quarry & QBY2a & 96 & 34.359 & 115.1330 & 0.712 & 0.002 & 2 & $>\mathrm{H}$ & $640 \pm 100 \mathrm{ka}$ \\
\hline Peppy Grove & WPM1a & 69 & No GPS & No GPS & 0.470 & 0.131 & 4 & $?$ & \\
\hline Mt Eliza & PEZ1a & 19,35 & 31.9631 & 115.8423 & ND & ND & 2 & $?$ & $>422 \mathrm{ka}(\mathrm{TL})$ \\
\hline
\end{tabular}

Rottnest Island (Hearty, 2003)

Aminozone $A$

Fairbridge Bluff

L. Astrg Bay W

Fairbridge Bluff

Rottnest Bore

Army Jetty

Herschell

Quarry

Herschell

Quarry

Aminozone C

Herschell dune

Herschell Hill

Henrietta

Rocks

Lake Vincent

Narrow Neck

Abraham's Bay

Oliver Hill base

Oliver Hill RR

Parakeet Bay

The Basin

Armstrong Hill

South Point

South Point

Kingston Brks

Crayfish Rock

Crayfish Rock

$\begin{array}{ll}\text { RFB1z } & 93 \\ \text { RLA2a } & 57 \\ \text { RFB1x } & 90 \\ \text { RRB1a } & 99 \\ \text { RAJ } & 98 \\ \text { RHQ1cd } & 90\end{array}$

RHQ1a(2)

98

RHE2

RHEla

RHT1a

RLV1a

RNN1a

RABla

ROLla

ROL2a

RPAla

RTBla (2)

RARla

RSPle

RSPlc

RKBla

RCF1c

RCFla

$\begin{array}{ll}32.0160 & 115.5121 \\ 31.9918 & 115.5053 \\ 32.0160 & 115.5121 \\ 31.9990 & 115.5385 \\ 32.0040 & 115.5039 \\ 31.9959 & 115.5250 \\ 31.9959 & 115.5250\end{array}$

0.049

0.097

0.126

0.133

0.120

0.089

0.131

31.9959

31.9955

31.9955

115.5251

115.5258

115.5258

0.187

0.210

32.0009

32.0153

$200 \mathrm{~m} \mathrm{~N}$

32.0071

32.0109

31.9990

31.9908

31.9946

32.0212

32.0212

32.0043

No GPS

No GPS
115.5126

115.4749

Of RNN

115.5158

115.5158

115.5121

115.5333

115.5039

115.4688

115.4688

115.5558

No GPS

No GPS

$\begin{array}{lll}0.000 & 2 & \text { A } \\ 0.007 & 2 & \text { A } \\ 0.001 & 2 & \text { A } \\ 0.007 & 2 & \text { A } \\ 0.000 & 2 & \text { A } \\ 0.005 & 4 & \text { A } \\ 0.005 & 4 & \text { A }\end{array}$

${ }^{14} \mathrm{C}$; Table 3

${ }^{14} \mathrm{C}$; Table 3

${ }^{14} \mathrm{C}$; Table 3

${ }^{14} \mathrm{C}$; Table 3 
Table Al (continued)

\begin{tabular}{|c|c|c|c|c|c|c|c|c|c|}
\hline Site name & $\begin{array}{l}\text { Field } \\
\text { number }\end{array}$ & $\mathrm{Ca} \mathrm{CO}_{3}$ & $\begin{array}{l}\text { Latitude } \\
\left({ }^{\circ} \mathrm{S}\right)\end{array}$ & $\begin{array}{l}\text { Longitude } \\
\left({ }^{\circ} \mathrm{E}\right)\end{array}$ & $\begin{array}{l}A / I \text { (site } \\
\text { mean) }\end{array}$ & \pm 1 & $N$ & Aminozone & $\begin{array}{l}\text { AAE age, }{ }^{14} \mathrm{C} \\
\text { or U/Th } \\
\text { calibration }\end{array}$ \\
\hline L. Astrg Bay E & RLAle & 95 & 31.9924 & 115.5051 & 0.235 & 0.004 & 2 & $\mathrm{C} 2$ & \\
\hline L Astrg Bay E & RLAlc & 95 & 31.9924 & 115.5051 & 0.276 & 0.008 & 2 & $\mathrm{C} 1$ & \\
\hline Fish Hook Bay & RFH1g & 99 & 32.0246 & 115.4494 & 0.227 & 0.002 & 2 & $\mathrm{C} 2$ & \\
\hline Fish Hook Bay & RFHle & 98 & 32.0246 & 115.4494 & 0.243 & 0.008 & 2 & $\mathrm{Cl}$ & \\
\hline Fish Hook Bay & RFH1c & 94 & 32.0246 & 115.4494 & 0.263 & 0.007 & 2 & $\mathrm{C} 1$ & \\
\hline City of York & RCYlc & 99 & 31.9969 & 115.4941 & 0.203 & 0.006 & 2 & $\mathrm{C} 2$ & ${ }^{14} \mathrm{C}$; Table 3 \\
\hline City of York & RCY1a & 81 & 31.9969 & 115.4941 & 0.254 & 0.016 & 2 & $\mathrm{Cl}$ & \\
\hline Bathurst Light & $\mathrm{RBH} 2 \mathrm{c}$ & 94 & $100 \mathrm{~m} \mathrm{~W}$ & Of RHB1 & 0.252 & 0.012 & 2 & $\mathrm{Cl}$ & \\
\hline Bathurst Point & RBH1a & 93 & 31.9917 & 115.5408 & 0.312 & 0.019 & 2 & $>\mathrm{C} ?$ & \\
\hline Fairbridge Bluff & RFB4x & 96 & $0.5 \mathrm{~km} \mathrm{E}$ & Of RFB1 & 0.232 & 0.007 & 2 & $\mathrm{C} 2$ & \\
\hline Fairbridge Bluff & RFB5a & 98 & Q at road & Near RFB1 & 0.222 & 0.012 & 2 & $\mathrm{C} 2$ & \\
\hline Fairbridge Bluff & RFB1c & 82 & 32.0160 & 115.5121 & 0.245 & 0.021 & 2 & $\mathrm{Cl}$ & \\
\hline Jeannie's LO & RJL1c & 97 & 32.0272 & 115.5224 & 0.261 & 0.080 & 2 & $\mathrm{Cl}$ & \\
\hline Mary Cove East & RMB2g & 97 & $200 \mathrm{~m} \mathrm{E}$ & Of RMB1 & 0.165 & 0.004 & 4 & $\mathrm{C} 2$ & \\
\hline Mary Cove East & RMB2e & 95 & $200 \mathrm{~m} \mathrm{E}$ & Of RMB1 & 0.200 & 0.008 & 2 & $\mathrm{C} 2$ & \\
\hline $\begin{array}{l}\text { Mary Cove } \\
\text { West }\end{array}$ & RMBle & 90 & 32.0191 & 115.4909 & 0.280 & 0.004 & 2 & $\mathrm{Cl}$ & \\
\hline \multicolumn{10}{|l|}{ Aminozone $E$} \\
\hline Fairbridge Bluff & RFB1a & 98 & 32.0160 & 115.5121 & 0.344 & 0.080 & 4 & $\mathrm{E}$ & U/Th; Table 4 \\
\hline Jeannie's LO & RJL2a & 97 & $0.5 \mathrm{~km} \mathrm{~N}$ & Of RJL1 & 0.371 & 0.008 & 2 & $\mathrm{E}$ & \\
\hline $\begin{array}{l}\text { Mary Cove } \\
\text { West }\end{array}$ & RMBlc & 99 & 32.0191 & 115.4909 & 0.339 & 0.056 & 4 & $\mathrm{E}$ & \\
\hline $\begin{array}{l}\text { Mary Cove } \\
\text { West }\end{array}$ & RMB1a & 96 & 32.0191 & 115.4909 & 0.340 & 0.018 & 2 & $\mathrm{E}$ & \\
\hline \multicolumn{10}{|l|}{ Region II WR } \\
\hline \multicolumn{10}{|l|}{ Aminozone $A$} \\
\hline Hamelin Pool & SHPlx & & No GPS & No GPS & 0.057 & 0.000 & 2 & A & \\
\hline Geraldton & WGE2x & & 28.799 & 114.6186 & 0.064 & 0.007 & 2 & A & \\
\hline Broadhurst $\mathrm{N}$ & SBN1c(1) & 55 & No GPS & No GPS & 0.064 & 0.001 & 1 & A & \\
\hline \multicolumn{10}{|l|}{ Aminozone $C$} \\
\hline Eagle Bluff & SEB41 & 77 & 26.0818 & 113.5782 & 0.257 & 0.001 & 2 & A & \\
\hline Geraldton & WGE1x & & 28.789 & 114.6209 & 0.261 & 0.007 & 2 & $\mathrm{C}$ & \\
\hline Quobba & LQB1 & 56 & 25.364639 & 114.4069 & 0.264 & 0.023 & 2 & $\mathrm{C}$ & \\
\hline Cape Burney & GCB4x & 64 & 28.869 & 114.6329 & 0.292 & 0.014 & 2 & $\mathrm{C}$ & \\
\hline Goulet Bluff & SGT5b & & 26.19824 & 113.6834 & 0.293 & 0.070 & 4 & $<\mathrm{C} ?$ & \\
\hline Wooramel & SWR1 & & No GPS & No GPS & 0.293 & 0.030 & 2 & $<\mathrm{C} ?$ & \\
\hline \multicolumn{10}{|l|}{ Aminozone $E$} \\
\hline Tetradon & STD1x & & No GPS & No GPS & 0.415 & 0.008 & 2 & $<\mathrm{E} ?$ & \\
\hline Eagle Lookout & SEL5k & & 26.0818 & 113.5782 & 0.432 & 0.010 & 2 & $<\mathrm{E} ?$ & \\
\hline Cape Cuvier N & LCC1h & 61 & 24.215806 & 113.4184 & 0.482 & 0.025 & 2 & $\mathrm{E}$ & \\
\hline Cape Burney & GCB1c(3) & 56 & 28.869 & 114.6329 & 0.484 & 0.034 & 2 & $\mathrm{E}$ & U/Th; Table 4 \\
\hline Eagle Bluff & SEB1a & 28 & No GPS & No GPS & 0.487 & 0.030 & 2 & $\mathrm{E}$ & \\
\hline Baba Head & SBA1d & & 26.60264 & 113.6904 & 0.490 & 0.070 & 4 & $\mathrm{E}$ & \\
\hline Cape Burney & GCBld & 79 & 28.869 & 114.6329 & 0.494 & 0.086 & 2 & $\mathrm{E}$ & \\
\hline Fowler's Bay & SFW6a & 69 & 26.11042 & 113.6224 & 0.505 & 0.044 & 2 & $\mathrm{E}$ & \\
\hline Eagle Lookout & SEL4k & & 26.0818 & 113.5782 & 0.507 & 0.030 & 2 & $\mathrm{E}$ & \\
\hline Cape Burney & GCB1c(1) & 68 & 28.869 & 114.6329 & 0.522 & 0.041 & 2 & $\mathrm{E}$ & \\
\hline Hose Q & KHOl & 14 & 28.103583 & 114.2204 & 0.530 & 0.030 & 2 & $>\mathrm{E} ?$ & $296 \pm 40 \mathrm{ka}$ \\
\hline Gladstone N & SGN1a & & No GPS & No GPS & 0.591 & 0.020 & 2 & E1 & \\
\hline Fowler's Bay & SFW5a & & No GPS & No GPS & 0.599 & 0.050 & 2 & $\mathrm{E}$ & \\
\hline Cape Cuvier & LCV2.5f & & 24.22556 & 113.3914 & 0.621 & 0.067 & 2 & $\mathrm{E}$ & \\
\hline Fowler's Bay & SFW2d & 57 & 26.10651 & 113.6191 & 0.636 & 0.080 & 1 & $\mathrm{E}$ & \\
\hline Cape Cuvier & LCV7f & & 24.23446 & 113.3926 & 0.642 & 0.006 & 2 & $\mathrm{E}$ & \\
\hline Gladstone N & SGN1b & & No GPS & No GPS & 0.661 & 0.008 & 2 & E1 & \\
\hline Whalebone & SWB1c(3) & 54 & 26.13003 & 113.6401 & 0.671 & 0.111 & 1 & E1 & \\
\hline \multicolumn{10}{|c|}{ Aminozone $G$ and $H$} \\
\hline Cape Burney & GCB1a & 79 & 28.869 & 114.6329 & 0.685 & 0.014 & 2 & $\mathrm{H}$ & \\
\hline Quobba Quarry & LQQ1 & 64 & 24.356139 & 113.4114 & 0.817 & 0.025 & 2 & $\mathrm{G} / \mathrm{H} ?$ & \\
\hline Baba Head & SBA3b & & 26.60468 & 113.6920 & 0.965 & 0.010 & 2 & $\mathrm{H}$ & $460 \pm 50 \mathrm{ka}$ \\
\hline
\end{tabular}


Table Al (continued)

\begin{tabular}{lllllll}
\hline Site name & $\begin{array}{l}\text { Field } \\
\text { number }\end{array}$ & $\mathrm{Ca} \mathrm{CO}_{3}$ & $\begin{array}{l}\text { Latitude } \\
\left({ }^{\circ} \mathrm{S}\right)\end{array}$ & $\begin{array}{l}\text { Longitude } \\
\left({ }^{\circ} \mathrm{E}\right)\end{array}$ & $\begin{array}{l}A / I \text { (site } \\
\text { mean) }\end{array}$ & $\begin{array}{l}\mathrm{AAE} \text { age, }{ }^{14} \mathrm{C} \\
\text { or } \mathrm{U} / \mathrm{Th} \\
\text { calibration }\end{array}$
\end{tabular}

\begin{tabular}{|c|c|c|c|c|c|c|c|c|c|}
\hline \multicolumn{10}{|l|}{ Monkey Tarra } \\
\hline Monkey Tarra & SMT1D10 & 84 & 26.69273 & 113.60042 & 0.417 & 0.013 & 2 & $>\mathrm{C} ?$ & \\
\hline Monkey Tarra & SMT4D10 & 78 & 26.69481 & 113.60254 & 0.375 & 0.059 & 2 & $>\mathrm{C} ?$ & \\
\hline Monkey Tarra & SMT2(D4) & 74 & 26.69481 & 113.60254 & 0.080 & 0.081 & 2 & Unk & \\
\hline Monkey Tarra & SMT2(D6) & 59 & 26.69481 & 113.60254 & 0.712 & 0.072 & 2 & Unk & \\
\hline Monkey Tarra & SMT1(D5) & 81 & 26.69273 & 113.60042 & 0.802 & 0.006 & 2 & Unk & \\
\hline Monkey Tarra & SMT1(D5) & 60 & 26.69273 & 113.60042 & 0.525 & 0.010 & 2 & Unk & \\
\hline Monkey Tarra & SMT4 D10 & 89 & 26.6786 & 113.60561 & 0.717 & 0.018 & 2 & Unk & \\
\hline Monkey Tarra & SMT4 D10 & 96 & 26.69481 & 113.60254 & 0.576 & 0.013 & 2 & Unk & \\
\hline \multicolumn{10}{|c|}{ Woomerangee Hill } \\
\hline Woomerangee & SWG1(D9 & & 26.8836 & 113.7485 & 0.221 & 0.059 & 4 & Unk & \\
\hline Woomerangee & SWG1D9 & & 26.8837 & 113.7485 & 0.482 & 0.040 & 2 & Unk & \\
\hline Woomerangee & SWG1(D8 & & 26.8837 & 113.7485 & 0.421 & 0.100 & 2 & Unk & \\
\hline Woomerangee & SWG1(D4 & & 26.8837 & 113.7485 & 0.079 & 0.004 & 2 & Unk & \\
\hline Woomerangee & SWG1(D3 & & 26.8837 & 113.7485 & 0.107 & 0.010 & 2 & Unk & \\
\hline \multicolumn{10}{|l|}{ Region III WR } \\
\hline \multicolumn{10}{|l|}{ Aminozone $A$} \\
\hline Coral Bay & WCB2z & 71 & No GPS & No GPS & 0.045 & 0.010 & 2 & A & \\
\hline Coral Bay & WCE1a & 70 & No GPS & No GPS & 0.066 & 0.001 & 2 & A & \\
\hline Port Smith & BSM1a(1) & 54 & 18.45508 & 121.81384 & 0.097 & 0.020 & 2 & A & \\
\hline Port Smith & BSM1c & 64 & 18.45508 & 121.81384 & 0.11 & 0.009 & 2 & A & \\
\hline Port Smith & BSMla(2) & 51 & 18.45508 & 121.81384 & 0.111 & 0.027 & 2 & A & ${ }^{14} \mathrm{C}$; Table 3 \\
\hline $\begin{array}{l}\text { Pinnacles young } \\
\text { dunes in NP }\end{array}$ & WCP5e & 38 & No GPS & No GPS & 0.120 & 0.016 & 2 & A & \\
\hline Port Smith & BSM1z & 73 & 18.45508 & 121.81384 & 0.144 & 0.068 & 2 & A & \\
\hline Jacobesz & WJZ2z & 91 & 21.82397 & 114.08483 & 0.157 & 0.005 & 2 & A & \\
\hline Cape Vlaming & WVL2x & 79 & No GPS & No GPS & 0.224 & 0.013 & 2 & A & \\
\hline \multicolumn{10}{|l|}{ Aminozone $E$} \\
\hline Jacobesz & WJZle & 90 & 21.82397 & 114.08483 & 0.556 & 0.064 & 2 & $\mathrm{E}$ & U/Th; Table 4 \\
\hline Mangrove Bay & WMV1a & 88 & No GPS & No GPS & 0.661 & 0.077 & 2 & $\mathrm{E}$ & $\mathrm{U} / \mathrm{Th}$; Table 4 \\
\hline Coral Bay & WCB1x & 86 & No GPS & No GPS & 0.670 & 0.026 & 2 & $\mathrm{E}$ & \\
\hline \multicolumn{10}{|c|}{ Aminozone $G / H$ and $H$} \\
\hline Pilgrimana & NPGla & & 22.19268 & 113.86925 & 0.710 & 0.060 & 2 & $\mathrm{G} / \mathrm{H}$ & \\
\hline Pilgrimana & NPG1c & & 22.19268 & 113.86925 & 0.792 & 0.030 & 2 & $\mathrm{G} / \mathrm{H}$ & \\
\hline Coral Bay & WCRla & 80 & No GPS & No GPS & 0.794 & 0.024 & 2 & $\mathrm{G} / \mathrm{H}$ & \\
\hline Tanatbiddi & WTIla & 95 & No GPS & No GPS & 0.829 & 0.008 & 2 & $\mathrm{G} / \mathrm{H}$ & \\
\hline Exmouth & WEX1a & 70 & No GPS & No GPS & 0.895 & 0.048 & 2 & $\mathrm{H}$ & $\geqslant 325 \pm 50 \mathrm{ka}$ \\
\hline \multicolumn{10}{|c|}{ Marine shells (Aminozones as indicated) } \\
\hline $\begin{array}{l}\text { Broadhurst } \\
\text { Bight }\end{array}$ & SBH1a(2) & Cer & 25.5437 & 113.4901 & 0.825 & 0.013 & 2 & $\mathrm{E}$ & \\
\hline Talleifer & STF2 & Cer & 26.15414 & 113.71074 & 0.728 & 0.035 & 2 & $\mathrm{E}$ & \\
\hline \multicolumn{10}{|l|}{ Isthmus } \\
\hline Baba Head & SBAld & Cer & 26.60264 & 113.69037 & 0.734 & 0.006 & 2 & $\mathrm{E}$ & U/Th; Table 4 \\
\hline Broadhurst & SBHla(1) & Brah & 25.5437 & 113.4901 & 0.029 & 0.003 & 2 & A & \\
\hline \multicolumn{10}{|l|}{ Bight } \\
\hline Baba Head & SBA1d & Brac & 26.60264 & 113.69037 & 1.003 & 0.034 & 2 & $\mathrm{E}$ & $\mathrm{U} / \mathrm{Th}$; Table 4 \\
\hline Goulet Bluff & SGT5b & Brac & 26.19824 & 113.68341 & 0.984 & 0.080 & 2 & $\mathrm{E}$ & \\
\hline Tetradon Loop & STD4a & Brac & No GPS & No GPS & 0.868 & 0.006 & 1 & $\mathrm{E}$ & \\
\hline Monkey Mia & SMM4 & Brac & No GPS & No GPS & 1.180 & 0.030 & 2 & $\mathrm{~F}$ ? & \\
\hline \multicolumn{10}{|c|}{ Region I Bothriembryon (Aminozones if known as indicated) } \\
\hline Blossom Beach & $\mathrm{ABB} 2 \mathrm{~b}$ & & 34.4572 & 119.3640 & 0.756 & 0.045 & 3 & $\mathrm{H} ?$ & \\
\hline Esperance & ENI4e & & 33.8377 & 121.9187 & 0.634 & 0.063 & 2 & $\mathrm{G} / \mathrm{H} ?$ & \\
\hline QB Quarry & QBY2b & & 34.359 & 115.1330 & 0.590 & 0.053 & 3 & $>\mathrm{H} ?$ & \\
\hline Cosy Corner & $\mathrm{CCR} 4 \mathrm{e}$ & & 34.266 & 115.0341 & 0.407 & 0.052 & 3 & $\mathrm{E}$ & \\
\hline Foul Bay & MFU1d & & 34.249 & 115.0284 & 0.337 & 0.077 & 4 & $\mathrm{E}$ & $\mathrm{U} / \mathrm{Th}$; Table 4 \\
\hline Hamelin Bay & WHBle & & 34.224 & 115.0239 & 0.096 & 0.005 & 3 & A & \\
\hline Hamelin Bay & WHB1b & & 34.224 & 115.0239 & 0.283 & 0.005 & 3 & $\mathrm{E}$ & \\
\hline Guilderton & PGU5b & & 31.353 & 115.4976 & 0.591 & 0.049 & 2 & $\mathrm{E}$ & \\
\hline
\end{tabular}


Table Al (continued)

\begin{tabular}{|c|c|c|c|c|c|c|c|c|c|}
\hline Site name & $\begin{array}{l}\text { Field } \\
\text { number }\end{array}$ & $\mathrm{Ca} \mathrm{CO} 3$ & $\begin{array}{l}\text { Latitude } \\
\left({ }^{\circ} \mathrm{S}\right)\end{array}$ & $\begin{array}{l}\text { Longitude } \\
\left({ }^{\circ} \mathrm{E}\right)\end{array}$ & $\begin{array}{l}A / I \text { (site } \\
\text { mean) }\end{array}$ & \pm 1 & $N$ & Aminozone & $\begin{array}{l}\text { AAE age, }{ }^{14} \mathrm{C} \\
\text { or } \mathrm{U} / \mathrm{Th} \\
\text { calibration }\end{array}$ \\
\hline Herschell dune & RHE 1b & & 31.9959 & 115.5251 & 0.176 & 0.000 & 0 & A & \\
\hline City of York & RCY $1 b$ & & 31.9969 & 115.4941 & 0.330 & 0.020 & 2 & $\mathrm{C}$ & ${ }^{14} \mathrm{C}$; Table 3 \\
\hline \multicolumn{10}{|c|}{ Region II Shark Bay Bothriembryon } \\
\hline Tamala Hwy & STL 3 & & No GPS & No GPS & 0.021 & 0.001 & 2 & A & ${ }^{14} \mathrm{C}$; Table 3 \\
\hline Monkey Tarra & SMT1D10 & & 26.69273 & 113.60042 & 0.051 & 0.016 & 3 & A & ${ }^{14} \mathrm{C}$; Table 3 \\
\hline Monkey Tarra & SMT4 S10 & & 26.6786 & 113.6056 & 0.167 & 0.063 & 3 & A & ${ }^{14} \mathrm{C}$; Table 3 \\
\hline Brickies Sd Pit & SBSla & 15 & 25.92952 & 113.5440 & 0.172 & 0.062 & 5 & A & \\
\hline \multicolumn{10}{|l|}{ Aminozone $B$} \\
\hline Goulet Bluff & SGT1c & & 26.20547 & 113.6888 & 0.244 & 0.071 & 3 & $\mathrm{~B}$ & \\
\hline Eagle Bluff & SEB41 & 77 & 26.0818 & 113.5782 & 0.271 & 0.037 & 4 & $\mathrm{~B}$ & \\
\hline Eagle Bluff & SEB41 & 77 & 26.0818 & 113.5782 & 0.287 & 0.025 & 3 & $\mathrm{~B}$ & \\
\hline \multicolumn{10}{|l|}{ Aminozone $C-E$} \\
\hline Little lagoon & SLL1a & 59 & 25.90531 & 113.5440 & 0.570 & 0.007 & 1 & $\mathrm{C}-\mathrm{E}$ & \\
\hline Monkey Mia & SMM1c & 5 & 25.794611 & 113.7190 & 0.655 & 0.061 & 4 & $\mathrm{C}-\mathrm{E}$ & \\
\hline Monkey Mia & SMM2b & & 25.794611 & 113.7190 & 0.680 & 0.091 & 3 & $\mathrm{C}-\mathrm{E}$ & \\
\hline Monkey Mia & $\mathrm{SMM} 2 \mathrm{~b}$ & & 26.794611 & 114.7190 & 0.732 & 0.004 & 2 & $\mathrm{C}-\mathrm{E}$ & \\
\hline Eagle Bluff & SEB1d & & $\begin{array}{l}80 \mathrm{~m} \mathrm{E} \text { of } \\
\text { SEL4 }\end{array}$ & $\begin{array}{l}80 \mathrm{~m} \mathrm{E} \text { of } \\
\text { SEL4 }\end{array}$ & 0.732 & 0.023 & 3 & $\mathrm{C}-\mathrm{E}$ & \\
\hline Eagle Lookout & SEL 4k & & 26.0818 & 113.5782 & 0.763 & 0.044 & 2 & $\mathrm{C}-\mathrm{E}$ & \\
\hline Eagle Bluff & SEB4h(2) & 14 & 26.0818 & 113.5782 & 0.791 & 0.121 & 4 & $\mathrm{C}-\mathrm{E}$ & \\
\hline Eagle Lookout & SEL2h & 28 & 26.08832 & 113.5780 & 0.791 & 0.083 & 2 & $\mathrm{C}-\mathrm{E}$ & \\
\hline \multicolumn{10}{|l|}{ Aminozone $E$} \\
\hline Eagle Lookout & SEL3h & 32 & 26.0818 & 113.5782 & 0.813 & 0.116 & 4 & $\mathrm{E}$ & \\
\hline Eagle Bluff & SEB $1 b$ & 19 & $\begin{array}{l}80 \mathrm{~m} \text { E of } \\
\text { SEL4 }\end{array}$ & $\begin{array}{l}80 \mathrm{~m} \text { E of } \\
\text { SEL4 }\end{array}$ & 0.827 & 0.004 & 2 & $\mathrm{E}$ & \\
\hline Eagle Bluff & SEB $1 b$ & 19 & $\begin{array}{l}80 \mathrm{~m} \text { E of } \\
\text { SEL4 }\end{array}$ & $\begin{array}{l}80 \mathrm{~m} \text { E of } \\
\text { SEL4 }\end{array}$ & 0.840 & 0.064 & 4 & $\mathrm{E}$ & \\
\hline Eagle Bluff & SEB4h(3) & 14 & 26.0818 & 113.5782 & 0.846 & 0.101 & 4 & $\mathrm{E}$ & \\
\hline \multicolumn{10}{|l|}{ Aminozones $\mathrm{F}-\mathrm{H}$} \\
\hline Eagle Lookout & SEL1c & 11 & 26.09179 & 113.5789 & 0.865 & 0.430 & 4 & $>\mathrm{F}$ & \\
\hline Tetradon & \#3 STD 5 & & No GPS & No GPS & 0.867 & 0.050 & 2 & $\mathrm{~F}-\mathrm{H}$ & \\
\hline Eagle Lookout & SEL1f(2) & 30 & 26.09179 & 113.5789 & 0.952 & 0.034 & 3 & $\mathrm{~F}-\mathrm{H}$ & \\
\hline Tetradon & \#1 STD la & & No GPS & No GPS & 0.989 & 0.170 & 2 & $\mathrm{~F}-\mathrm{H}$ & \\
\hline Tetradon & \#2 STD $2 \mathrm{a}$ & & No GPS & No GPS & 1.009 & 0.017 & 2 & $\mathrm{~F}-\mathrm{H}$ & \\
\hline Eagle Lookout & SELlc & 11 & 26.09179 & 113.5789 & 1.073 & 0.156 & 3 & $>\mathrm{G} / \mathrm{H}$ & \\
\hline Eagle Lookout & SEL1c & 11 & 26.09179 & 113.5789 & 1.156 & 0.084 & 2 & $>\mathrm{G} / \mathrm{H}$ & \\
\hline \multicolumn{10}{|l|}{ Monkey Tarra } \\
\hline Monkey Tarra & SMT1D10) & & 26.69273 & 113.60042 & 0.051 & 0.016 & 3 & A & \\
\hline Monkey Tarra & SMT4S10) & & 26.6786 & 113.60561 & 0.167 & 0.063 & 3 & A & \\
\hline Monkey Tarra & SMT2(S6) & & 26.69481 & 113.60254 & 0.674 & 0.256 & 5 & $?$ & \\
\hline Monkey Tarra & SMT2(S6) & & 26.69481 & 113.60254 & 0.678 & 0.049 & 3 & $?$ & \\
\hline Monkey Tarra & SMT2(D5) & & 26.69481 & 113.60254 & 0.788 & 0.127 & 7 & $?$ & \\
\hline Monkey Tarra & SMT1(D6) & & 26.69273 & 113.60042 & 0.790 & 0.152 & 5 & $?$ & \\
\hline Monkey Tarra & SMT2(D6) & & 26.69481 & 113.60254 & 0.830 & 0.087 & 5 & $?$ & \\
\hline Monkey Tarra & SMT2(D6) & & 26.69481 & 113.60254 & 0.853 & 0.101 & 3 & $?$ & \\
\hline Monkey Tarra & SMT1(D6) & & 26.69273 & 113.60042 & 0.917 & 0.071 & 2 & $?$ & \\
\hline
\end{tabular}

Note: AAE = age based on amino acid epimerization and apparent parabolic kinetic model. U/Th ages are in Table 4 and Stirling et al. (1995, 1998; references therein). ${ }^{14} \mathrm{C}$ ages are in Table 3 and Playford (1997). 


\section{Editorial Handling by: D. Kaufman}

\section{References}

Allayialis, D., 2003. The sedimentary characteristics of peri-continental dune deposits in Western Australia. Honours Thesis, James Cook University, Townsville, QLD, 89pp.

Bastian, L.V., 1996. Residual soil mineralogy and dune subdivision, Swan Coastal Plain, Western Australia. Australian Journal of Earth Sciences 43, 31-44.

Bretz, J.H., 1960. Bermuda: a partially drowned late mature Pleistocene karst. Geological Society of America Bulletin 71, 1729-1754.

Brooke, B., 2001. The distribution of carbonate eolianite. Earth Science Reviews 55, 135-164.

Cheng, H., Edwards, R.L., Hoff, J., Gallup, C.D., Richards, D.A., Asmerom, Y., 2000. The half-lives of uranium-234 and thorium-230. Chemical Geology 169, 17-33.

Donald, A.J., 2003. Marine and continental sediment flux in Shark Bay, Western Australia. Honours Thesis, James Cook University, Townsville, Queensland, 104pp.

Eberhard, S., 2004. Ecology and hydrology of a threatened groundwaterdependent ecosystem: the Jewel Cave Karst System in Western Australia. Unpublished Ph.D. Thesis, Murdoch University, Perth, Western Australia, 364pp.

Fairbridge, R.W., Teichert, C., 1953. Soil horizons and marine bands in the coastal limestones of Western Australia. Royal Society of New South Wales Journal and Proceedings 86, 68-87.

Fletcher III., C.H., Murray-Wallace, C., Glenn, C.R., Sherman, C.E., Popp, B., Hessler, A., 2005. Age and origin of late Quaternary eolianite, Kaiehu Point (Moomomi), Molokai, Hawaii. Journal of Coastal Research 42, 97-112.

Gill, E.D., 1968. Quaternary shorelines research in Australia and New Zealand. Australian Journal of Science 31 (3), 106-111.

Goodfriend, G.A., Gould, S.J., 1996. Paleontology and chronology of two evolutionary transitions by hybridization in the Bahamian land snail Cerion. Science 274, 1894-1897.

Goodfriend, G.A., Stipp, J.J., 1983. Limestone and the problem of radiocarbon dating of land-snail shell carbonate. Geology 11, 575-577.

Hearty, P.J., 1998. The geology of Eleuthera Island, Bahamas: a Rosetta Stone of Quaternary stratigraphy and sea-level history. Quaternary Science Reviews 17, 333-355.

Hearty, P.J., 2002a. Revision of the late Pleistocene stratigraphy of Bermuda. Sedimentary Geology 153 (1-2), 1-21.

Hearty, P.J., 2002b. The Kaena highstand on Oahu, Hawaii: Further evidence of Antarctic Ice collapse during the middle Pleistocene. Pacific Science 56 (1), 65-82.

Hearty, P.J., 2003. Stratigraphy and ages of fossil carbonate deposits of Rottnest Island, Western Australia. Quaternary Research 60, 211-222.

Hearty, P.J., Kaufman, D.S., 2000. Whole-rock aminostratigraphy and Quaternary sea-level history of the Bahamas. Quaternary Research 54, 163-173.

Hearty, P.J., Kindler, P., 1997. The stratigraphy and surficial geology of New Providence Island, Bahamas. Journal of Coastal Research 13 (3), 798-812.

Hearty, P.J., Vacher, H.L., 1994. Quaternary stratigraphy of Bermuda: A high-resolution pre-Sangamonian rock record. Quaternary Science Reviews 13, 685-697.

Hearty, P.J., Miller, G.H., Stearns, C., Szabo, B.J., 1986. Aminostratigraphy of Quaternary shorelines around the Mediterranean basin. Geological Society of America Bulletin 97, 850-858.

Hearty, P.J., Vacher, H.L., Mitterer, R.M., 1992. Aminostratigraphy and ages of Pleistocene limestones of Bermuda. Geological Society of America Bulletin 104, 471-480.

Hearty, P.J., McNeill, D.F., Land, L., Dill, R.F., 1996. Stratigraphy and ages of two $33 \mathrm{~m}$ long bank-margin cores from the Exuma Cays, Bahamas. In: Proceedings and Abstracts, American Association of Petroleum Geologists, San Diego, CA, A63.
Hearty, P.J., Kindler, P., Cheng, H., Edwards, R.L., 1999. A $+20 \mathrm{~m}$ middle Pleistocene sea-level highstand (Bermuda and the Bahamas) due to partial collapse of Antarctic ice. Geology 27, 375-378.

Hearty, P.J., Kaufman, D.S., Olson, S.L., James, H.F., 2000. Stratigraphy and whole-rock amino acid geochronology of key Holocene and Last Interglacial carbonate deposits in the Hawaiian Islands. Pacific Science 54 (4), 423-442.

Hearty, P.J., O’Leary, M.J., Kaufman, D.S., Page, M., Bright, J., 2004a. Amino acid geochronology of individual foraminifer (Pulleniatina obliquiloculata) tests, north Queensland margin, Australia: a new approach to correlating and dating Quaternary tropical marine sediment cores. Paleoceanography 19, 4022-4036.

Hearty, P.J., Olson, S.L., Kaufman, D.S., Edwards, R.L., Cheng, H., 2004b. Stratigraphy and geochronology of pitfall accumulations in caves and fissures, Bermuda. Quaternary Science Reviews 23, 1151-1171.

Hearty, P.J., Karner, D.B., Renne, P.R., Olson, S.L., Fletcher, S., 2005a. ${ }^{40} \mathrm{Ar} /{ }^{39} \mathrm{Ar}$ age of a young rejuvenation basalt flow: Implications for the duration of volcanism and the timing of carbonate platform development during the Quaternary on Kaua'i, Hawaiian Islands. New Zealand Journal of Geology and Geophysics 48, 199-211.

Hearty, P.J., James, H., Olson, S.L., 2005b. The geological context of paleo-lakes and Pleistocene birds at Ulupau Head, O'ahu, Hawaiian Islands. In: Alcover, J.A., Bover, P. (Eds.), Insular Vertebrate Evolution: the Palaeontological Approach. Monografies de la Societat d'Història Natural de les Balears, September 2003, Mallorca, Spain, pp. 113-128 (390pp).

Hearty, P.J., O’Leary, M.J., Donald, A., Lachlan, T., 2006. The enigma of 3400 cal yr BP coastal oolites in Tropical northwest Western Australia... why then, why there? Sedimentary Geology 186, 171-185.

Hearty, P.J., Hollin, J.T., Neumann, A.C., O’Leary, M.J., McCulloch, M., 2007. Global sea-level fluctuations during the last integlaciation (MIS 5e). Quaternary Science Reviews, doi:10.1016/j.quascirev.2007.06.019.

James, N.P., Collins, L.B., Bone, Y., Hallock, P., 1999. Subtropical carbonates in a temperate realm: modern sediments on the southwest Australian shelf. Journal of Sedimentary Research 69 (6), 1297-1321.

James, N.P., Bone, Y., Kyser, T.K., Dix, G.R., Collins, L.B., 2004. The importance of changing oceanography in controlling late Quaternary carbonate sedimentation on a high-energy, tropical, oceanic ramp: north-western Australia. Sedimentology 51, 1179-1205.

Kendrick, G.W., 1978. New species of fossil nonmarine molluscs from Western Australia and evidence of late Quaternary climate change in the Shark Bay district. Journal of the Royal Society of Western Australia 60 (2), 49-60.

Kendrick, G.W., Wyrwoll, K.-H., Szabo, B.J., 1991. Pliocene-Pleistocene coastal events and history along the western margin of Australia. Quaternary Science Reviews 10, 419-439.

Kindler, P., Hearty, P.J., 1996. Carbonate petrology as an indicator of climate and sea-level changes: new data from Bahamian Quaternary units. Sedimentology 43, 381-399.

Kinna, B., 2002. Biogenic sediment flux on Rottnest Island and the Perth region. Unpublished Honours Thesis, James Cook University, Townsville, Queensland, Australia.

Land, L.S., Mackenzie, F.T., Gould, S.J., 1967. The Pleistocene history of Bermuda. Geological Society of America Bulletin 78, 993-1006.

Logan, B.W., Read, J.F., Davies, G.R., 1970. History of carbonate sedimentation, Quaternary Epoch, Shark Bay, Western Australia. In: Carbonate Sedimentation and Environments, Shark Bay, Western Australia, American Association of Petroleum Geologists Memoir, pp. 38-84.

Logan, B.W., Read, J.F., Hagan, G.M., Hoffman, P., Brown, R.G., Woods, P.J., Gebelein, C.D., 1974. Evolution and diagenesis of Quaternary carbonate sequences, Shark Bay, Western Australia. AAPG Memoir 22, 358.

McCulloch, M.T., Esat, T., 2000. The coral record of Last Interglacial sea levels and sea surface temperatures. Chemical Geology 169, 107-129.

McNamara, K., 2002. The Pinnacles. Western Australia Museum, Perth, $25 \mathrm{pp}$. 
Miller, G.H., Brigham-Grette, J., 1989. Amino acid geochronology: resolution and precision in carbonate fossils. Quaternary International $1,111-128$

Mitterer, R.M., Kriausakul, N., 1989. Calculation of amino acid racemization ages based apparent parabolic kinetics. Quaternary Science Reviews 8, 353-357.

Munsell Soil Color Charts (2002 revised ed.). Macbeth Division of Kollmorgan Instruments Corporation, New Windsor, NY 12553.

Murray-Wallace, C.V., Kimber, R.W.L., 1989. Quaternary marine aminostratigraphy: Perth Basin, Western Australia. Australian Journal of Earth Science 36, 553-568.

Murray-Wallace, C.V., Brooke, B.P., Cann, J.H., Belperio, A.P., Bourman, R.P., 2001. Whole-rock aminostratigraphy of the Coorong, Coastal Plain, South Australia: towards a 1 million year record of sealevel highstands. Journal of the Geological Society of London 158, $111-124$.

Neumann, A.C., Hearty, P.J., 1996. Rapid sea-level changes at the close of the Last Interglacial (Stage 5e) recorded in Bahamian Island geology. Geology 24, 775-778.

O'Leary, M.J., 2007. The stratigraphy and geochronology of emergent fossil reef deposits of Western Australia: Unpublished Ph.D. Thesis, James Cook University, Townsville, Australia, 170pp.

O'Leary, M.J., Hearty, P.J., McCulloch, M.T. U-series evidence for widespread reef development in Shark Bay during the last interglacial. Palaeogeography, Palaeoclimatology and Palaeoecology, in press.

O'Leary, M.J., Hearty, P.J., McCulloch, M.T. Morphostratigraphic evidence for unstable sea levels during marine isotope stage 5e: Cape Cuvier, Western Australia. Quaternary Research, in review.

Playford, P.E., 1990. Geology of the Shark Bay area, Western Australia. In: Berry, P.F., Bradshaw, S.D., Wilson, B.R. (Eds.), Research in Shark Bay, Report of the France-Australe Bicentenary Expedition Committee. Western Australian Museum, Perth, pp. 13-31.

Playford, P.E., 1997. Geology and hydrology of Rottnest Island, Western Australia. In: Vacher, H.L., Quinn, T. (Eds.), Geology and Hydrology of Carbonate Islands, pp. 783-810.

Playford, P.E., Cope, R.N., Cockbain, A.E., Low, G.H., Lowry, D.C., 1975. Phanerozoic, in geology of Western Australia. Western Australia Geological Survey Memoire 2, 223-433.
Playford, P.E., Cockbain, A.E., Low, G.H., 1976. Geology of the Perth Basin, Western Australia. Western Australia Geological Survey Bulletin 124, 311pp.

Price, D.M., Brooke, B.P., Woodroffe, C.D., 2001. Thermoluminescence dating of eolianites from Lord Howe Island and south-west Western Australia. Quaternary Science Reviews 20, 841-846.

Raymo, M.E., Ruddiman, W.F., Shackleton, N.J., Oppo, D.W., 1990. Evolution of Atlantic-Pacific $\delta^{13} \mathrm{C}$ gradients over the last $2.5 \mathrm{~m} . \mathrm{yr}$. Earth Planetary Science Letters 97, 353-368.

Reimer, P.J., et al., 2004. IntCal04 terrestrial radiocarbon age calibration, 26-0 ka BP. Radiocarbon 46, 1029-1058.

Roof, S., 1997. Comparison of isoleucine epimerization and leaching potential in the molluscan genera Astarte, Macoma, and Mya. Geochimica et Cosmochimica Acta 61 (24), 5325-5333.

Sayles, R.W., 1931. Bermuda during the Ice Age. American Academy of Arts and Sciences 66, 381-468.

Semeniuk, V., Glassford, D.K., 1988. Significance of eolian limestone lenses in quartz sand formations: an interdigitation of coastal and continental facies, Perth Basin, southwestern Australia. Sedimentary Geology 57, 199-209.

Stirling, C.H., Esat, T.M., McCulloch, M.T., Lambeck, K., 1995. Highprecision U/Th; Tab 4 dating of corals from Western Australia and implications for the timing and duration of the Last Interglacial. Earth and Planetary Science Letters 135, 115-130.

Stirling, C.H., Esat, T.M., Lambeck, K., McCulloch, M.T., 1998. Timing and duration of the Last Interglacial: evidence for a restricted interval of widespread coral reef growth. Earth and Planetary Science Letters $160,745-762$.

Stuvier, M., Reimer, P.J., Bard, E., Beck, J.W., Burr, G.S., Hughen, K.A., Kromer, B., McCormac, G., van der Plicht, J., Spurk, M., 1998. INTCAL 98 radiocarbon age calibration, 24,000-0 cal BP. Radiocarbon 40, 1041-1083.

Stuiver, M., Reimer, P.J., Reimer, R.W., 2005. CALIB 5.0.2. [www program and documentation].

Teichert, C., 1950. Late Quaternary changes of sea-level at Rottnest Island, Western Australia. Proceedings of the Royal Society of Victoria 59, 63-79.

Vacher, H.L., Hearty, P.J., 1989. History of stage-5 sea level in Bermuda with new evidence of a rise to present sea level during substage 5a. Quaternary Science Reviews 8, 159-168. 